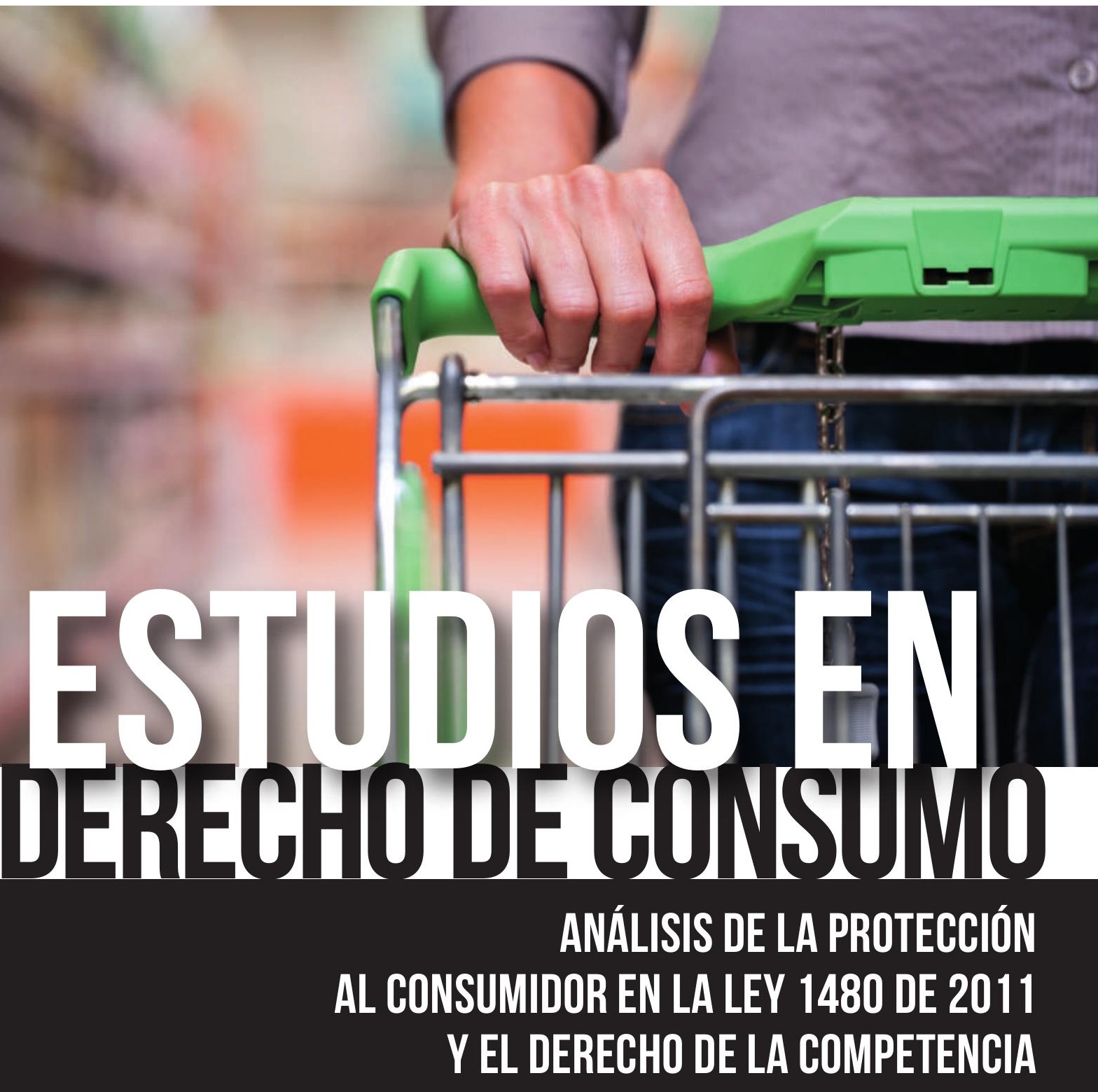

\title{
AUTORES
}

CARLOS ARTURO HERNÁNDEZ DÍAZ NOHORA ELENA PARDO POSADA PAOLA ANDREA ZULUAGA ORTIZ LEONARDO ACEVEDO VALENCIA 




\title{
ESTUDIOS EN DERECHO DE CONSUMO
}

\author{
ANÁlISIS DE LA PROTECCIÓN AL \\ CONSUMIDOR EN LA LEY I 480 DE 20 I I \\ Y EL DERECHO DE LA COMPETENCIA
}




\section{UNVERSIDAD LA GRAN COLOMBIA}

Fundador

Julio César García Valencia (I884-1959)

Presidente

José Galat Noumer

Rector

Santiago José Castro Agudelo

Vicerrector Académico

Rodrigo Lupercio Riaño Pineda

Vicerrectora Administrativa

María del Pilar Galat Chediak

Secretaria General

Marco Tulio Calderón Peñaloza

Decana Facultad de Derecho

Gloria Inés Quiceno Franco

Directora de Investigaciones

Beatriz Helena Robayo Castro
INSTITUCIÓN UNIVERSITARIA

POLITÉCNICO GRANCOLOMBIANO

Rectoría

Fernando Dávila Ladrón de Guevara

Vicerrectoría Académica

Jurgen Chiari Escobar

Vicerrectoría de Desarrollo Institucional

Javier Arango Pardo

Vicerrectoría de Estudiante

Alejandra Ordóñez Ospina

Vicerrectoria Administrativa y Financiera

Juan Camilo Pardo Acevedo

Secretaria General

Billy Escobar Pérez

Secretaria Académica

Sergio Hernández Muñoz

Facultad de Ciencias Sociales

Carlos Augusto García López 


\title{
ESTUDIOS EN \\ DERECHO DE CONSUMO
}

\author{
ANÁlisis DE LA PROTECCIÓN AL \\ CONSUMIDOR EN LA LEY I 480 DE 20 I I \\ Y EL DERECHO DE LA COMPETENCIA
}

\section{COMPILADORES}

María Alejandra lacayo Arana

Javier Francisco Franco Mongua

\section{AUTORES}

Carlos Arturo Hernández Díaz

Nohora Elena Pardo Posada

Paola Andrea Zuluaga Ortiz

Leonardo Acevedo Valencia 
Estudios en derecho de consumo

Análisis de la protección al consumidor en la ley 1480 de 2011

y el derecho de la competencia

Primera edición: Abril de 2018

ISBN: 978-958-8721-64-4

EISBN: 978-958-8721-66-8

EBOOK: 978-958-8721-65-1

Publicaciones Politécnico Grancolombiano

Eduardo Norman Acevedo

Lider de Publicaciones

Calle 57 \# 3-00 Este

PBX: 7455555 ext. 1171

E-mail: editorial@poligran.edu.co

Bogotá-Colombia

Dirección Editorial Universidad La Gran Colombia

Beatriz Helena Robayo Castro

Directora de Investigaciones

Calle 12C No. 5-15.

Teléfono: 2826386 ext: 188 - 232

E-mail: investigaciones.editorial@ugc.edu.co

direccion.investigaciones@ugc.edu.co

\section{Compiladores}

María Alejandra Lacayo Arana

Abogada

Javier Francisco Franco Mongua

Universidad La Gran Colombia

\section{Autores}

Carlos Arturo Hernández Díaz

Universidad La Gran Colombia

Nohora Elena Pardo Posada

Universidad La Gran Colombia

Paola Andrea Zuluaga Ortiz

Institución Universitaria Politécnico Grancolombiano

Leonardo Acevedo Valencia

Docente de la Universidad Libre

Analista de Producción Editorial

Paulo Mora Noguera

\section{Diseño y Armada Electrónica}

Huevofrito SAS

\section{Corrección de Estilo}

Gustavo Quesada

Impresión

Xpress Estudio Gráfico y Digital S.A.

Impreso en Colombia

Printed in Colombia

La editorial de la Institución Universitaria Politécnico Grancolombiano pertenece a la Asociación de Editoriales Universitarias de Colombia ASEUC.

"Las opiniones plasmadas en esta obra son de responsabilidad exclusiva de los autor, y no comprometen a las instituciones ni determinan su posición o filosofía institucional".

Ninguna parte de esta publicación puede ser reproducida, almacenada o trasmitida de manera alguna, ni por ningún medio, ya sea electrónico, químico, mecánico, óptico, de grabación o fotocopia, sin permiso escrito de la Institución Universitaria Politécnico Grancolombiano y de la Universidad La Gran Colombia.

\section{¿Como citar este libro?}

Lacayo-Arana et al. (2018), Estudios en derecho de consumo: Análisis de la protección al consumidor en la ley 1480 de 2011 y el derecho de la competencia, Bogotá: Publicaciones Politécnico Grancolombiano / Universidad La Gran Colombia. 


\section{ONTENIDO}

PRÓLOGO

I. INTRODUCCIÓN

II. EL PRINCIPIO DE LA AUTONOMÍA DE LA VOLUNTAD EN LOS CONTRATOS CON CONDICIONES GENERALES EN EL ORDENAMIENTO COLOMBIANO 45

1. Introducción $\quad 47$

1.1. Autonomía privada y condiciones generales de la contratación $\quad 54$

2. Protección a la autonomía privada en el derecho de consumo $\quad 59$

2.1. El control del contenido en los contratos de adhesión 61

2.2. El concepto de cláusula abusiva y cláusula prohibida 62

2.3. La lista de cláusula abusivas $\quad 64$

2.4. El control formal de las Condiciones Generales 66

2.5. La interpretación e integración de las Condiciones Generales $\quad 68$

3. Conclusiones $\quad 71$

III. LA RELACIÓN CONSUMIDOR, DISTRIBUIDOR Y PROVEEDOR BAJO EL ESTATUTO DEL CONSUMIDOR 77

1. Introducción $\quad 79$

2. El Estatuto del Consumidor y su armonización con el orden jurídico colombiano

2.1. Responsabilidad civil 83

2.2. Responsabilidad contractual 86

2.3. Responsabilidad extracontractual $\quad 87$

2.4. Antecedentes normativos de la Ley 1480

3. Las Contextualizaciones constitucionales del Decreto 3466 de 1982 y en el Estatuto del Consumidor 90

3.1. Contexto Constitucional del Decreto 3466

3.2. La constitucionalización del Derecho del Consumidor, Ley 1480 de 201191

3.3. Diferencias Conceptuales: Decreto 3466 de 1982 y Ley 1480 de 201192

3.3.1. Las Facultades de la Superintendencia de Industria y Comercio. $\quad 98$

4. El Concepto de Calidad en el Estatuto del Consumidor- Ley 1480 de 2011101 
IV. El USUARIO DE LOS SISTEMAS PIRAMIDALES: ¿CONSUMIDOR A PROTEGER O (IR) RACIONAL APROVECHADOR DEL ESTADO? 107

$\begin{array}{ll}1 . \text { Introducción } & 109\end{array}$

1.1. La racionalidad del inversor $\quad 111$

1.2. El caso Interbolsa $\quad 116$

1.3. El problema 118

2. De la racionalidad económico- jurídica de los individuos 119

3. Esquema ponzi o piramidal 122

3.1. Contribución a la exoneración de responsabilidad del Estado $\quad 128$

4. El usuario como inversionista 130

5. El usuario como consumidor $\quad 132$

6. Las consecuencias de la responsabilidad del Estado 136

7. Conclusiones 141

\section{LAS FACULTADES JURISDICCIONALES DE LA SIC EN EL MARCO}

DEL PRINCIPIO DE LA LEGALIDAD 151

1. Introducción 153

1.1. Protección de los consumidores: entre el mandato constitucional y la potestad de configuración del Legislador

2. La asignación de funciones jurisdiccionales a la SIC

2.1. Reglas constitucionales relativas a la atribución de funciones judiciales a las autoridades administrativas 160

2.2. Doctrina probable de la SIC. Razones para adoptar el precedente 161

2.2.1. Competencias Jurisdiccionales que cumple la SIC. En materia de protección al consumidor $\quad 165$

2.3. Garantías constitucionales en la acción jurisdiccional 203

3. Conclusiones 173

VI. LOS CARTELES DE EXPORTACIÓN Y SUS EFECTOS 177

1. Introducción 179

2. Efectos de los carteles dentro de un mercado de libre competencia 181

2.1. Los carteles como práctica restrictiva de la competencia 181

2.1.1. La existencia de un pacto 186

2.1.2. La independencia de los involucrados 188

2.1.3. El comportamiento voluntario, intencional y coordinado 190 
2.1.4. La inestabilidad potencial

2.1.5. Planeación anticipada e intencional de ventajas y desventajas $\quad 190$

2.1.6. Los carteles no tienen que producir efectos reales 191

2.1.7.Que la no competencia genere beneficios 192

3. Formas y clases de carteles 192

3.1. Sobre la fijación de precios $\quad 192$

3.2. Sobre la repartición de mercados 194

3.3. Sobre la asignación de cuotas 196

3.4. Los carteles de importación 196

3.5. Los carteles internacionales 197

3.6. Los carteles de exportación 198

4. Alcance de los carteles de exportación 199

5. Efectos de los carteles en un tratado de libre comercio 203

6. Conclusiones 206

VII. LA COLUSIÓN EN LA CONTRATACIÓN ESTATAL Y LA PROTECCIÓN DE LA

COMPETENCIA: RETOS DEL NUEVO SISTEMA DE COMPRAS PÚBLICAS EN COLOMBIA 213

1. Introducción 215

2. El marco legal y reglamentario aplicable a las conductas colusorias en el mercado de compras públicas en Colombia 219

3. Mecanismos establecidos en el EGCAP para evitar las prácticas colusorias 223

3.1. Aplicación del Régimen de inhabilidades 223

3.2. La exclusión de los oferentes coludidos o la declaratoria de desierta de los procesos de selección con ofertas producidas por acuerdos colusorios

4. Mecanismos para contrarrestar los efectos de las prácticas colusorias establecidas en el EGCAP

4.1. La acción de repetición $\quad 230$

4.2. La declaratoria de caducidad del contrato 232

5. La colusión y el proyecto de reforma al EGCAP presentado por

Colombia Compra Eficiente

6. Conclusiones 



\section{PRÓLOGO \\ José López-OLIVA*}

n mi proceso de formación para optar el título de abogado en Colombia y posteriormente en la formación complementaria en el exterior, era muy común que los profesores - especialmente de derecho privado- fundamentaran sus reflexiones acerca de la equidistancia e igualdad que debe existir entre las partes. Era un hecho conocido que además de la autonomía de la voluntad, la igualdad entre los extremos contractuales se instituía como una consideración básica a la hora de analizar las relaciones positivas y negativas en el mundo del derecho civil. Esto, a pesar que desde el siglo XIX se empezó a reconocer que en situaciones concretas era un hecho cierto que las partes no eran económica o políticamente iguales: gran parte de las relaciones en el mundo se apoyaban en dicha realidad.

Así, por ejemplo, el Capítulo VII relacionado con el arrendamiento de “criados" domésticos o del Título XXVI atienten al contrato de arrendamiento y del Libro IV que hace alusión a las obligaciones en general y de los contratos -del Código Civil- fue subrogado por el Código Sustantivo del Trabajo con una regulación sobre trabajadores del servicio doméstico. Se llegaba -luego de debates políticos y jurídicos - al reconocimiento de una realidad 
inobjetable: en el mundo del derecho no siempre las partes tienen la condición de iguales; por el contrario: ante el desequilibrio en el mundo, corresponde al derecho hacer una tarea de equiparación: el trabajador —el obrero de la revolución industrial — debía ser protegido frente al industrial o gran comerciante que de ser contratante en una relación civil, entre iguales, se convertía primero en "patrono" y luego — cambios del lenguaje— en empleador. Todo lo anterior, en una situación de desequilibrio que igualaba o intentaba hacerse a través de la ley laboral con una evidente pero fallida dimensión social.

Además, mis profesores a finales del siglo XX seguían observando el mundo jurídico como un plano de equidistancias, sin ondulaciones de ningún tipo, con la sola excepción del derecho del trabajo. Esto empezó a cambiar — muy marginalmente- con la expedición en 1982 del Decreto 3466 que se convirtió en el primer estatuto del Consumidor. Así, Colombia acogía la tendencia que venía de los países industrializados desde el clásico discurso del Presidente Kennedy el 15 de marzo de 1962, en la que se reconocía una realidad de la sociedad industrial:

"Consumidores, por definición, somos todos. Son el grupo mayoritario de la economía, afectando y siendo afectados por la práctica totalidad de las decisiones económicas públicas y privadas. Dos tercios del gasto total en la economía provienen de los consumidores. Pero son el único grupo importante en la economía que no están organizados eficazmente, cuya opinión es a menudo ignorada".

Asimismo, el presidente Kennedy mostraba una realidad insoslayable: la sociedad industrial posterior a la II Guerra Mundial:

\footnotetext{
1. KENNEDY, John F. Extractos del discurso se pueden escuchar en la página electrónica de la Bibliotea y Museo del Presidente Kennedy https:// www.jfklibrary.org/Asset-Viewer/Archives/JFKWHA-080-003.aspx consultada el 14 de Noviembre de 2017. La versión en cita es de la traducción del texto del discurso tomada de http://www.aytojaen.es/portal/RecursosWeb/DOCUMENTOS/1/2_13065_1.pdf consultada el 14 de Noviembre de 2017.
} 
“La evolución de la tecnología - afectando por ejemplo a los alimentos que consumimos, las medicinas que tomamos y muchos de los electrodomésticos que usamos en nuestros hogares- ha incrementado las dificultades del consumidor al tiempo que sus oportunidades; y ha invalidado mucha de la legislación anterior y hecho necesaria una nueva regulación. El supermercado típico de antes de la II Guerra Mundial almacenaba en torno a 1.500 productos alimenticios distintos, una cantidad impresionante como se mire. Pero en la actualidad maneja en torno a los 6.000. El 90\% de las recetas médicas que se emiten actualmente son de medicinas que eran totalmente desconocidas hace 20 años. Muchos de los nuevos productos de uso diario en los hogares son altamente complejos. Se requiere al ama de casa para que sea un electricista amateur, o un mecánico, químico, toxicólogo, dietista y matemático, pero en raras ocasiones se le proporciona la información que necesita para desempeñar estas tareas adecuadamente.

La comercialización es cada vez más impersonal. La decisión del consumidor se ve influenciada por la publicidad masiva que utiliza mecanismos de persuasión altamente desarrollados. Normalmente el consumidor no puede saber si la elaboración de las medicinas reúne los estándares mínimos de seguridad, calidad y eficacia. Normalmente tampoco sabe cuánto paga por los préstamos al consumo; si una comida preparada tiene mayor poder nutritivo que otra; si el resultado de un producto satisfará sus necesidades; o si el "paquete tamaño económico" es realmente una ganga" ${ }^{2}$.

Se evidencia cómo, desde hace más de cincuenta años, en este discurso se observan delineados los problemas fundantes del derecho del consumo: La

\footnotetext{
2. KENNEDY, John F. Extractos del discurso se pueden escuchar en la página electrónica de la Bibliotea y Museo del Presidente Kennedy https:// www.jfklibrary.org/Asset-Viewer/Archives/JFKWHA-080-003.aspx consultada el 14 de Noviembre de 2017. La versión en cita es de la traducción del texto del discurso tomada de http://www.aytojaen.es/portal/RecursosWeb/DOCUMENTOS/1/2_13065_1.pdf consultada el 14 de Noviembre de 2017.
} 
relación de consumo, la dificultad en la organización de los consumidores, la desigualdad entre el consumidor y los empresarios, la publicidad y sus problemas, entre otros. Desde estas épocas se perfila algo que posteriormente será estudiado - ya no solo por el derecho- sino por otras ciencias sociales como la sociología, la psicología del consumo, entre otros.

Así las cosas, se reconoce que ese desarrollo tecnológico que conduce a un bienestar en la vida cotidiana — alimentos procesados, medicamentos, electrodomésticos- implica que tenga un correlato, una consecuencia de riesgo o hecho incierto que no depende de la voluntad del productor, comercializador o el consumidor. Así lo describe el sociólogo alemán Ulrick Beck en su la clásica obra, La Sociedad del Riesgo ${ }^{3}$; y que también ha sido objeto de reflexión del sociólogo británico - y el más destacado en esa disciplina en su país durante el último medio siglo- Anthony Giddens en su libro Un mundo desbocado: los efectos de la globalización en nuestros dias ${ }^{4}$.

Pero volvamos al discurso del Presidente Kennedy. Para él los consumidores tienen cuatro derechos principales:

"Necesitamos acción legislativa y administrativa adicional, no obstante, si el Gobierno Federal tiene que hacer frente a su responsabilidad de cara a los consumidores en el ejercicio de sus derechos.

Éstos incluyen:

1. El derecho a la seguridad, a ser protegidos contra la comercialización de productos que sean peligrosos para la salud o la vida.

3. BECK, Ulrick. LA SOCIEDAD DEL RIESGO. Paidos. Buenos Aires. 1998.

4. GIDDENS, Anthony. UN MUNDO DESBOCADO: LOS EFECTOS DE LA GLOBALIZACIÓN EN NUESTROS DÍAS. Taurus, 2003. 
2. El derecho a la información, a ser protegidos contra la información, publicidad, etiquetado, o cualesquiera otras prácticas fraudulentas, engañosas o básicamente confusas, y a que le sean suministrados todos los bechos que necesita para tomar una decisión basada en la información.

3. El derecho a elegir, a que se le asegure, siempre que sea posible, el acceso a una variedad de productos y servicios a precios competitivos; y en aquellos sectores en los que la competencia no es operativa y la regulación gubernamental es reemplazada, la seguridad de una calidad y servicio satisfactorio a los mejores precios.

4. El derecho a ser oídos, a tener la seguridad de que los intereses de los consumidores serán tenidos de total y comprensivamente en consideración la elaboración de las políticas del Gobierno, y a un tratamiento adecuando y ágil en los tribunales administrativos. Para promover el mayor cumplimiento de estos derechos de los consumidores, es necesario que los programas vigentes del Gobierno sean reforzados, una mejora en la organización gubernamental, y, en determinadas áreas, que se implemente nueva legislación”.

Insisto: esos puntos tratados por el presidente Kennedy en 1962, siguen teniendo hoy vigencia no solo en la legislación nacional - “nuevo” estatuto del Consumidor - ley 1480 de 2011 — sino en el debate legislativo y político nacional.

A su vez, en la Cámara de Representantes se tramita el proyecto de ley 233 de 2017 "por medio de la cual se crean medidas para regular la publicidad dirigida a los niños, niñas y adolescentes para la protección de sus derechos” ${ }^{5}$.

\footnotetext{
5. Al respecto se puede consultar en la página de la Imprenta Nacional la Gaceta del Congreso número 179 de 2017. Igualmente se pueden leer las interesantes intervenciones desde distintos enfoques en el debate en la Comisión Primera en torno a este proyecto. Particularmente resultan ilustrativas las intervenciones del profesor de la Universidad Militar Nueva Granada Dr. Juan Carlos Villalba Cuellar y del vocero de la Liga de Consumidores de Bogotá Con-summa en convenio con la Universidad La Gran Colombia Javier Francisco Franco Mongua. Ver: http://www.camara.gov. co/sites/default/files/2017-06/Aportes\%20radicados\%20en\%20audiencia\%20p\%C3\%BAblica\%20Mayo\%2022\%20de\%202017..pdf Consultado el 15 de Noviembre de 2017.
} 
Igualmente, otras organizaciones radicaron otro proyecto de ley con un objetivo similar ${ }^{6}$. El debate ha llegado incluso a los más importantes medios de comunicación de Colombia ${ }^{7}$.

De ser un tema "marginal” hace unas décadas, la protección al consumidor ha llegado a ser un aspecto de debate central en la sociedad civil y políticas nacionales.

Sin embargo, la contracara del derecho del consumidor, es el derecho contra las prácticas restrictivas de la competencia y los llamados "cárteles". Investigaciones recientes adelantadas por la Superintendencia de Industria y Comercio, siguiendo sus competencias y los mandatos de la ley 155 de 1959, el decreto 2153 de 1992 y la ley 1340 de 2009, especialmente con el sistema de incentivos - diseñado a partir de la teoría de juegos-; lo precedente, ha permitido que las delaciones lleven a encontrar que hay mercados con presunta existencia de carteles, en mercados como el de pañales, papel higiénico, azúcar, cemento, y al parecer la lista puede seguir de forma indeterminada, pero finita; así se espera principalmente por parte de los consumidores: los más afectados.

$\mathrm{Y}$ es sobre estos temas que nos presentan en conjunto este libro, conformado por capítulos que son el resultado de investigaciones serias y realizadas por investigadores de gran prestigio a nivel nacional e internacional. Estos documentos han sido sometidos a evaluación por pares académicos del programa de Derecho de la Facultad de Ciencias Sociales de la Institución Universitaria Politécnico Gran Colombiano y la Universidad La Gran Colombia; este texto representa un gran aporte por su calidad y pertinencia, a la más reciente bibliografía iberoamericana sobre la materia. ${ }^{8}$

\footnotetext{
6. https://www.dejusticia.org/proyecto-ley-busca-regular-publicidad-de-alimentos-no-saludables-dirigida-a-menores/ consultado el 15 de Noviembre de 2017.

7. https://www.elespectador.com/opinion/editorial/hablar-de-comida-chatarra-articulo-722011 Consultado el 15 de Noviembre de 2017 y http:// www.eltiempo.com/opinion/editorial/no-a-la-comida-chatarra-mala-alimentacion-en-ninos-149448 consultado el 15 de Noviembre de 2017. 
Tengo la convicción que este libro será de referencia obligada para todo aquel que quiera hoy en nuestro medio, encontrar un panorama sobre el derecho de la competencia y la protección al consumidor.

GUAL ACOSTA, José Manuel y VILLALBA CUELLAR Juan Carlos, Directores, Gustavo Ibañez Ed. Y Universidad Santo Tomás, Bogotá. 2013. HEREDIA QUERRO, Juan Sebástian. Et al. LEY DE DEFENSA DEL CONSUMIDOR Comentada, anotada y concordada. Ed. Errepar Buenos Aires. 2013. ALVAREZ RUBIO, Julio (Coordinador) LA PROTECCIÓN JURÍDICA DE LOS CONSUMIDORES EN EL ESPACIO EUROAMÉRICANO, Comares, Granada 2014. 

INTRODUCCIÓN 

1 derecho de consumo y la protección a los consumidores, son temas que están ocupando particularmente a la doctrina colombiana desde la entrada en vigencia del Estatuto del Consumidor en 2011, y a raíz de sus posteriores reglamentaciones, las cuales ponen en perspectiva el entendimiento que de ella deben hacer los consumidores en general, y los consumidores sectoriales, respecto al ámbito de aplicación de la misma y al alcance y trascendencia de sus preceptos.

Así, se empieza por desarrollar el concepto de autonomía de la voluntad, visto ahora sí, en el ejercicio del derecho a contratar de las personas, en el marco de sus relaciones de consumo, donde alguna vez se llegó a cuestionar la validez de estos actos, con el entendido de que la adhesión no constituye un verdadero consentimiento.

Superada esta cuestión, en cuanto la interpretación que puede llegar a hacerse del artículo 855 del código de comercio,,debe entenderse que la adhesión simple y llana a la propuesta es aceptación, y por lo tanto, se perfecciona el consentimiento, dando paso al análisis de las transformaciones 
a las que el derecho privado, particularmente el derecho de consumo, se ha visto enfrentado en virtud de las exigencias y demandas de la sociedad moderna, y por las que ha tenido que hacer modificaciones y replanteamientos de sus principios y reglas más fundamentales, a través de inclusiones expresas y concretas en la norma, pero cuyo alcance va más allá de lo que puede entenderse en la literalidad.

Vemos entonces, cómo allí, donde los contratos son predispuestos y una de las partes ha tenido que aceptar cláusulas preestablecidas por la otra parte que posee la comprensión sobre el alcance del contenido del contrato, va delimitándose el ejercicio de la autonomía con mayor rigurosidad, o más bien, se va dejando menos margen de acción a los consumidores en sede de contratación, prohibiéndole a las partes contratantes incluir cierto contenido, a pesar de su voluntad, porque el legislador ha considerado que para la efectiva protección de los consumidores hay derechos a los que estos no pueden renunciar, por una parte, y por otra, obligaciones que los productores y proveedores no pueden dejar de cumplir.

Se configuran entonces los controles al contrato de consumo, controles que la doctrina comparada ha denominado de contenido y de incorporación., El primero, que se materializa en una cláusula general que establece el criterio de abusividad y le da al juez la facultad de determinar, juicio a priori, si las cláusulas contenidas en un contrato con consumidores son abusivas o no, criterio que viene determinado por el desequilibrio en perjuicio del consumidor.

Junto a este criterio general, se establece una lista de cláusulas abusivas consideradas así de pleno derecho, que no permiten juicio en contrario y cuyo cumplimiento no queda sometido a la voluntad de las partes en cuanto se trata de verdadero derecho imperativo, de una lista negra de cláusulas que serán consideradas abusivas en cualquier circunstancia en la que actúe un consumidor. 
Por su parte, el control de forma o control de incorporación, configurado mediante un deber de información correcta, tanto en la forma de redacción que garantice el entendimiento del alcance del contenido de las cláusulas, como en la oportunidad con que esta información debe ser dada con el fin de perfeccionar el consentimiento, el conocimiento efectivo por parte del consumidor de las condiciones bajo las cuales contrata, o al menos la posibilidad de conocimiento efectivo que no puede darse de manera correcta sin el correlativo deber de informarse del consumidor, o lo que es lo mismo, sin la debida diligencia en el ejercicio de sus derechos.

Así, al analizar el derecho de consumo y su implementación en Colombia, se parte de la preceptiva constitucional expuesta en el artículo 78 con un especial énfasis en la calidad de los bienes y servicios ofrecidos y los deberes que de ella se derivan, verbigracia el suministro de información adecuada, pertinente y veraz. De allí el carácter garantista de la carta política que en palabras de la Corte Constitucional propende por la debida protección de las partes inmersas en la relación comercial consumidor y quien produce y comercializa bienes y servicios.

No obstante, el capítulo va más allá de la exposición constitucional, y se introduce en el ámbito de la responsabilidad civil, partiendo de sus antecedentes en el Derecho Romano y sus premisas de no dañar al otro y dar a cada uno lo suyo, entre otras.

Por tanto, la responsabilidad en la actividad de consumo se enmarca en la concepción de daño o perjuicio causado a otro, debido al ejercicio de la actividad jurídico mercantil y se orienta a forjar soluciones eficientes para quien sufre detrimento en el curso normal de sus negocios civiles y comerciales, siendo esencial su resarcimiento mediante un pago de indemnización de perjuicios.

Con la pretensión de integralidad, los autores van más allá de la visión jurídica y afirman cómo la noción de responsabilidad puede apreciar- 
se desde el aspecto filosófico a partir de la concepción de libertad; afirman que el ser humano es libre de sus actos pero esclavo de sus consecuencias, y que frente a la producción de daños no se puede aceptar la impunidad porque ella llevaría al relajamiento de la disciplina y convivencia sociales. Una posición semejante implicaría que la víctima debe soportar, sin más, los daños injustificados, y que por tanto el responsable está exento de indemnizarlos., en detrimento de los valores y principios que la filosofía ha abanderado.

A su turno, presentando los argumentos del maestro Hinestrosa en su Tratado de las Obligaciones, afirman que en la responsabilidad contractual se obliga no solo al cumplimiento de lo pactado, sino también a todas las consecuencias del contrato que generó las obligaciones, sea este unilateral, bilateral, oneroso, conmutativo, consensual, instantáneo o de tracto sucesivo, encontrándose en la falta a su puntual cumplimiento la responsabilidad del pago de daños y perjuicios.

Ya en la materia del derecho al consumo, los autores analizan el estatuto del consumidor, iniciando con sus antecedentes en la Ley 73 de 1981 que creó mecanismos, procedimientos, organismos y regulaciones, a través de las cuales el gobierno contó con facultades para intervenir en el control de la distribución de bienes y servicios; estas facultades se relacionaron especialmente con el establecimiento de la responsabilidad de los productores por la idoneidad y la calidad de los productos y servicios ofrecidos, así como por las leyendas, marcas y la publicidad empleadas para su comercialización.

La mencionada normatividad fue reglamentada por el Decreto 1441 que presentó como gran garantía a favor de los consumidores la creación y el reconocimiento de las ligas y asociaciones de consumidores, cuyo objeto consistió en garantizar la protección, información, educación, representación y respeto de los derechos de los consumidores de bienes y servicios; así mismo velar por el pago de las indemnizaciones, entidades que 
persisten a la fecha y que se han constituido en verdaderos mecanismos para la debida protección de la relación de consumo.

Es de especial significación para el orden jurídico el Decreto 3466 de 1982, que se mantuvo vigente hasta la expedición de la Ley 1480 de 2011, por cuanto en él se definieron los términos productor, proveedor o expendedor y consumidor, propaganda comercial, idoneidad, calidad y registro de bienes y servicios. También se delimitaron aspectos como garantía mínima presunta, marcas, leyendas, propagandas, obligaciones, sistemas de fijación de precios máximos al público, responsabilidad, indemnización de perjuicios y causales de exoneración para productores por idoneidad de bienes y servicios.

Para otorgar eficacia al modelo de estado descentralizado, la Ley 446(1998) otorgó competencias jurisdiccionales a la Superintendencia de Industria y Comercio en asuntos de competencia desleal. A su vez, como ha dicho la doctrina, la Ley reguló el control de calidad de bienes y servicios ofrecidos y prestados a la comunidad, como también el deber de suministrar información al público durante la comercialización, lo que llevó a configurar un tipo de responsabilidad civil objetiva o riesgo creado.

Llama la atención el tema de la calidad inserto en el estatuto del consumidor que se manifiesta entre otros aspectos en las unidades legales de medida usadas para la navegación marítima, por razones de investigación científica o por razones de seguridad. La metrología se funda en lo señalado por la OMC.

Sin embargo, se concluye que el estatuto de protección al consumidor Ley 1480 de 2011 no aporta grandes cambios frente a las normas legales que se venían aplicando. Tampoco deroga ni remplaza las normas especiales de cada sector económico, ni hace obligaciones de resultado a todas aquellas en las que resulte involucrado un consumidor con un productor o proveedor de cualquier producto o servicio. 
El ejercicio responsable y consciente de la autonomía privada que obliga al consumidor a asumir las consecuencias de sus propias acciones, ha sido también abordado en nuestro estudio desde la perspectiva sectorial, analizando mediante un estudio de caso en el que se parte desde la certeza de que existe un grado de racionalidad en los individuos-ciudadanos-inversores que participaron en los esquemas piramidales, y que generaron la crisis socioeconómica de 2008 en Colombia. Considera que la racionalidad intrínseca de los ciudadanos debe ser evaluada al momento de determinar la responsabilidad de los mismos en el surgimiento, acogida, desarrollo y caída de las pirámides; y en particular, en las pérdidas sufridas por ellos mismos. Como hipótesis fuerte, sostiene que -en tanto inversores- es irracional para los ciudadanos creer en los altos rendimientos ofrecidos por estas sociedades. Con base en esto, propone que es improcedente la reclamación de Responsabilidad del Estado por su obligación de vigilancia y control de dichas sociedades. Por el contrario -afirma- un análisis juicioso de la dinámica de las pirámides devela configurada la causal de exoneración tipificada como culpa exclusiva de la víctima, o en palabras llanas: los únicos responsables por las pérdidas generadas, son los inversores de estas sociedades.

Pero la protección al consumidor no puede verse solamente desde la perspectiva del derecho privado. Como ya es comúnmente reconocido el derecho privado -como todas las áreas de la disciplina- se ha visto fuertemente influenciado por la perspectiva de la constitucionalización. Además de que debe reconocerse que el derecho sustancial no puede tener una efectiva aplicación sino existe el derecho de accionar ante las autoridades públicas con el fin de lograr la protección de los derechos de los particulares. Ahora bien, es necesario estudiar las competencias de dichas entidades en el campo de la protección al consumidor para el caso colombiano, que resulta muy particular, dadas las facultades jurisdiccionales de la Superintendencia de Industria y Comercio, reglado hoy en el artículo 24 del Código General del Proceso. 
Esto se analiza desde distintas perspectivas. En primera instancia, se exponen las competencias del legislador para regular el régimen de protección de los derechos del consumidor, dentro del cual está comprendida la forma en que se puede exigir la responsabilidad del productor, que debe tener en cuenta, la protección especial de esos derechos reconocida por la Carta y estar orientada hacia su completa efectividad. Estas competencias no son ilimitadas, tema que ha sido abordado por la corte constitucional que consideró el principio de libertad configurativa de los regímenes de protección especial, y se subordina al cumplimiento razonable del programa de defensa instituido por la propia Constitución, cuyo desarrollo se confía al órgano democrático. Por consiguiente, el legislador no goza de libertad absoluta para configurar el régimen de los derechos de los consumidores; en su accionar debe sujetarse al mandato superior para una integra protección, lo que implica la revisión del proceso productivo y con ello lograr normas que blinden de la desigualdad a los consumidores en las relaciones del mercado.

Pasando al tema central del capítulo, llama la atención en relación con las funciones jurisdiccionales de la SIC, el control constitucional que llevó a cabo la Corte Constitucional que se concentra en tres hipótesis con trato diferencial: la primera, cuando la función jurisdiccional se ejerce bajo imparcialidad e independencia, caso de la sentencia C-1143 de 2000, que declaró la constitucionalidad de la posibilidad de que la Superintendencia de Sociedades pudiera incoar la acción revocatoria concursal. En el segundo evento, no es posible distinguir la función de control y vigilancia de la jurisdiccional expuesto en la sentencia C-1641 de 2000, en relación con ciertas funciones judiciales de la Superintendencia Bancaria. Por último, cuando se presentan interferencias entre las funciones judiciales y las labores de vigilancia y control, lo que implica que la entidad ajuste su estructura y funcionamiento para proteger la imparcialidad de la función judicial. Para este caso, ver sentencia C-649 de 2001 en relación con las atribuciones judiciales de la Superintendencia de Industria y Comercio en materia de competencia desleal. Esta última posición fue reiterada para las funciones de la SIC en protección al consumidor. 
Posteriormente y trayendo un concepto propio de la jurisdicción ordinaria que data de 1887, se emplea la doctrina probable a los actos administrativos que contienen las decisiones de la SIC, con fundamento en la Ley 1340 de 2009 y bajo criterios sistemáticos considerados por el legislador conforme el artículo 333 constitucional que trata de la actividad económica y la iniciativa privada e impone el deber al Estado de evitar su restricción; con fundamento en ello y en la seguridad jurídica que debe acompañar a los ciudadanos se motivó la adopción de la doctrina probable por parte de la SIC.

Luego del análisis de la doctrina probable se aborda el tema de las funciones jurisdiccionales y su remisión al artículo 24 de la Ley 1562 de 2012, código general del proceso. Este lista los eventos de jurisdicción en seis numerales. Para el caso en estudio solo es pertinente el numeral 1 que señala las funciones de la SIC por violación a los derechos de los consumidores establecidos en el Estatuto del Consumidor y de las normas relativas a la competencia desleal.

Termina este capítulo con la remisión al debido proceso en la actuación jurisdiccional de la SIC. Bajo un análisis jurisprudencial del tema se afirma que su acatamiento garantiza la simetría entre el texto constitucional y legal otorgando la legalidad y legitimidad a las actuaciones de la SIC en el Estado Social de Derecho Colombiano.

Las más recientes experiencias en diversos sectores de la economía colombiana, han demostrado que la protección al consumidor no sería efectiva sin una regulación clara y eficaz al derecho de la competencia, dentro de un marco jurídico que garantice la libre concurrencia de empresas compitiendo entre sí, en las mismas condiciones, frente a unos consumidores responsables, quienes directamente deciden su permanencia o preferencia por determinados productos o servicios sin injerencias ni barreras innecesarias impuestas por terceros, sean los mismos empresarios o el Estado. 
En este sentido, se aborda el tema de los carteles, aquellos instrumentos por los cuales las empresas, mediante sus voluntades, a través de acuerdos escritos o cooperación efectiva no convenida formalmente, manipulan la competencia e inciden en el curso de las relaciones comerciales, afectando directamente al consumidor.

En el desarrollo del tema y a partir de la información arrojada por los casos de estudio y el análisis que de ellos hace la doctrina, se logra identificar que las formas de cartelización más utilizadas por las empresas colombianas e internacionales, son los acuerdos sobre fijación de precios, la repartición de mercado y la asignación de cuotas de producción y distribución.

En cuanto a los carteles de exportación, se analiza el problema de la territorialidad de la norma, en cuanto a que sus efectos se producen en un país diferente de aquel en que se originan los acuerdos, y lo complejo que resulta determinar los preceptos y el ordenamiento bajo los cuales se pueden sancionar, así como la cuestión de si estos se encuentran en el ámbito del derecho de la competencia o no, y sus efectos, que tanto para el mercado como para el consumidor directamente, se pueden producir en el marco de la aplicación de un tratado de libre comercio.

Se mencionan algunas de las investigaciones que por estas conductas antijurídicas se han ventilado y algunas de las sanciones impuestas por parte de la Superintendencia de Industria y Comercio a grandes sectores empresariales, muchos de ellos, con productos o servicios de primera necesidad a los que el consumidor colombiano forzosamente debe acceder, ocasionándoles con esto un grave perjuicio económico.

El tema de competencia, sin embargo, afecta tanto al sector privado como al público; no en vano se reconoce que uno de los aspectos más importantes en los regímenes de protección de la competencia, es el relativo al sistema de compras públicas mediante el cual las entidades del Estado, 
tras adelantar los procesos de selección de contratistas,, encuentran el bien o servicio adecuado para la satisfacción de una necesidad previamente identificada y cuya atención permite el logro de los fines esenciales del Estado definidos en la norma normarum.

El desarrollo de este sistema de compras estatales supone unas dinámicas especiales en el mercado dada la interrelación sui generis que existe entre sus participantes, el segmento de la economía al que se acude, así como en cuanto a su identificación, calidad e interacción de los agentes que concurren para la presentación de las diferentes ofertas que participarán en el trámite para la selección de la mejor opción.

Desde esta óptica, resulta evidente la necesidad de adelantar una revisión de la normatividad que regula la materia, así como las competencias que deben ejercer los servidores públicos encargados de la estructuración y dirección de los procesos de selección, así como de las actividades a su cargo durante la ejecución del contrato estatal que inciden en la protección de los intereses del Estado como consumidor.

En este contexto, resulta necesario realizar un análisis sobre: i) la normatividad en materia de defensa de la competencia que regula esta realidad en el país y su relación con las disposiciones aplicables a la contratación estatal en Colombia; así mismo revisar: ii) las normas especiales en materia de competencia creadas por la ley y el reglamento dentro del Estatuto General de Contratación de la Administración Pública y las disposiciones que lo complementan, analizando su suficiencia frente a los objetivos que persigue, así como: iii) un estudio con perspectiva crítica del alcance práctico de las diferentes actuaciones que pueden adelantar los servidores públicos con el fin de evitar la materialización de prácticas que afecten el mercado de las compras públicas, en consideración de los diferentes aspectos diferenciadores del sector propio al que acude el Estado para la satisfacción de sus necesidades, y, por último: iv) el planteamiento de determinados cursos de acción que podrían adoptarse con el fin de me- 
jorar el control de las conductas que afectan la competencia en los procesos de selección de contratista, como quiera que la asignación de la competencia privativa atribuida a la Superintendencia de Industria y Comercio para conocer de las investigaciones administrativas por infracción a las disposiciones sobre protección de la competencia que asignó la Ley 1340 de 2009, produce en la práctica una limitación para el adecuado control y prevención frente a la ocurrencia de tales afrentas al mercado de las compras públicas, en razón a la insuficiente capacidad humana y técnica del ente de supervisión, inspección y vigilancia, para atender las irregularidades presentadas en todo el territorio nacional.

Ahora bien, el estudio de las prácticas que afectan el desenvolvimiento adecuado del mercado de compras públicas en Colombia, debe abordar de manera obligatoria el análisis de una conducta típicamente atentatoria del régimen de competencia: la Colusión. Esta práctica se entiende como la acción adelantada entre dos o más personas que logran un acuerdo o convenio que afecta a un tercero, y representa un alto riesgo de ocurrencia durante los procesos de selección de contratista que adelantan a diario las entidades estatales..

El estudio de los aspectos señalados plantea más inquietudes que las respuestas que podrían obtenerse, en razón a la complejidad de las diferentes situaciones que usualmente se presentan, así como por la reducida capacidad institucional para el adecuado control de la problemática.

Así, surgen innumerables dudas que merecen un serio estudio académico como: ¿cuáles son las acciones concretas que pueden adelantarse para impedir la celebración de acuerdos específicos entre los oferentes en un proceso de selección de contratista, orientadas a la adjudicación del contrato en favor de uno de los proponentes en detrimento de los intereses públicos y los derechos de los demás participantes? ¿Cómo puede identificarse la conducta colusoria de las diferentes actuaciones que se presentan típicamente en un proceso de selección de contratista? ¿Es posible, a la luz 
del ordenamiento colombiano, detener un proceso de selección de contratista ante el riesgo de producción de los efectos del acuerdo colusorio? Si ello es así, ¿Cuál es el trámite (administrativo o judicial) que debe adelantarse y quién está legitimado para promoverlo y qué entidad (además de la Superintendencia de Industria y Comercio) es competente para decidir e imponer las sanciones correspondientes? ¿Existe la posibilidad de cuestionar la legalidad del negocio jurídico estatal si se demuestra que se celebró como resultado de la materialización de un acto de colusión? ¿La presencia del acuerdo colusorio limita efectivamente la posibilidad de las entidades públicas de contar con un mayor número de ofertas para evaluar?

Estas y otras inquietudes que nacen en virtud del análisis de las conductas que afectan la competencia en el mercado de compras públicas deben estudiarse con óptica académica pero con el firme propósito de presentar alternativas para mejorar la gestión de la administración pública.

Punto aparte merece la consideración sobre la ocurrencia de estas prácticas restrictivas de la competencia en los regímenes exceptuados, que se aplican en una gran proporción en el sector público, como quiera que por disposición legal existen entidades a las que se les ha permitido la aplicación de procedimientos especiales para la adquisición de sus bienes y servicios y que, por lo tanto, no son destinatarios de las normas legales y reglamentarias que componen el Estatuto General de Contratación Pública. Esta realidad hace que en la práctica se evidencie la coexistencia de un régimen público con diferentes regímenes privados para la satisfacción de necesidades del Estado, cuya satisfacción, pese a que se deben atender con recursos públicos, permite la interacción de diferentes personas naturales y jurídicas en procesos de selección como oferentes en el mercado sin el sometimiento a las reglas a las que están sometidas la mayoría de entidades estatales.

De esta forma la INSTITUCION UNIVERSITARIA POLITÉCNICO GRAN COLOMBIANO, su Facultad de Ciencias Sociales y su 
programa de Derecho, y la UNIVERSIDAD LA GRAN COLOMBIA a través de su Facultad de Derecho, presentan a la comunidad académica esta obra conjunta, que ha sido arbitrada y cuyos capítulos son, todos, resultado de proyectos de investigación con aval institucional, adelantados por sus docentes investigadores; con el apoyo, varios de ellos, de estudiantes vinculados a sus semilleros. Esto con el fin de contribuir al mejor entendimiento de un área del derecho que si bien no es tan reciente en el mundo jurídico -en Colombia un primer corpus normativo, Decreto 3466, se produjo hace cerca de treinta y cuatro años-, si ha tenido una mayor recepción en el campo jurídico y en la sociedad civil así como en los medios de comunicación en los últimos años, como resultado -entre otras razones- de la expedición de la Ley 1480 de 2011, conocida como el Estatuto del Consumidor.

Como lo expresara en su momento el profesor García Canclini, en su ya clásico libro "Consumidores y Ciudadanos", la nueva ciudadanía, de finales del siglo XX y principio del siglo XXI, no se ejerce solamente a través del voto, sino de los derechos y acciones que como consumidores tenemos todos en el mercado. Así el acto de consumo, no es solamente un acto meramente económico, a través de instrumentos jurídicos - los contratos-, sino que el consumo es, también, en esencia, un acto político.

El consumo sirve también para poder reconocerse y ser reconocido en la sociedad. En el título de su gran y también monumental obra, Bourdieu, resume lo que ello significa: "La distinción” con subtítulo "Criterio y bases sociales del gusto”, en donde explora a profundidad cómo a diferencia del análisis clásico del siglo XIX y de la primera mitad del siglo XX -tanto desde visiones liberales como marxistas- la personas se identificaban en el momento de la producción, burgués, empresario, obrero, proletario. En su obra, el sociólogo francés, nos enseñó que también, o esencialmente, las personas se pueden reconocer en el momento del consumo: una especie de "dime lo que consumes y te diré quién eres". 
Así pues, para la INSTITUCIÓN UNIVERSITARIA POLITÉCNICO GRAN COLOMBIANO, y para la UNIVERSIDAD LA GRAN COLOMBIA, es motivo de regocijo presentar un primer producto de un trabajo en equipo, que abre el camino, esperamos, a muchos y variados proyectos de colaboración en áreas investigativas, docentes y de proyección social, que esperamos permitan contribuir de mejor manera a cumplir sus objetivos académicos y sociales, haciendo sinergias por un mejor vivir en sociedad. La calidad de este primer trabajo deberá ser juzgada por los lectores, quienes además de imparciales son rigurosos, y los únicos destinatarios de este esfuerzo. 


\section{I. \\ EL PRINCIPIO DE LA AUTONOMÍA DE LA VOLUNTAD EN LOS \\ CONTRATOS CON CONDICIONES GENERALES EN EL ORDENAMIENTO COLOMBIANO*

\author{
María Alejandra Lacayo Arana \\ mlac20@hotmail.com
}

\footnotetext{
*El presente artículo es producto del trabajo de investigación realizado en el marco del Proyecto "El régimen de Contratación con condiciones generales a la luz del Estatuto del Consumidor colombiano y la protección contra cláusulas abusivas", que se adelanta dentro del Grupo "Economía Derechos y Globalización” del Departamento de Derecho y Ciencias Políticas de la Facultad de Ciencias Sociales de la Institución Universitaria Politécnico Grancolombiano.
} 

Resumen. La autonomía de la voluntad es uno de los principios rectores del derecho privado colombiano, pensada para unas relaciones entre particulares, negociando de igual a igual y estableciendo de mutuo acuerdo el contenido contractual en el que queda plasmada la voluntad de todas las partes contratantes. En los contratos con condiciones generales, el consentimiento se perfecciona de tal modo que una parte redacta y la otra se adhiere a unas estipulaciones preestablecidas por su contraparte, no quedándole más que aceptar o rechazar sin posibilidad de negociación alguna. ¿Es esto autonomía? ¿Es esto libertad contractual? El ejercicio de la autonomía de la voluntad quedará reducido a la facultad para decidir si contratar o no contratar, pero no, para incorporar el contenido regulatorio del contrato. Los límites en este sentido vienen dados por la particular forma de perfección del contrato mismo, incorporando criterios del derecho común como el de buena fe, mediante disposiciones que en el contrato negociado no tendrían cabida.

\section{Introducción}

En el derecho como en la vida, cada cosa que se hace involucra la autonomía, incluso el hecho de someternos a cosas que no queremos; es uno mismo en su individualidad quien decide si hace algo o no lo hace con las consecuencias propias de tal decisión. En la órbita de lo jurídico, las decisiones de acatar o no acatar ciertas normas de imperativo cumplimiento traerán también sus propias consecuencias y según sean, por el ejercicio de nuestra propia autonomía estaremos incluso llegando a perder la libertad.

El libre albedrío se dice en un lenguaje más trascendental, más místico, es ese con el que nacemos, que nos fue dado por un ser supremo y en cuyo ejercicio debemos asumir las consecuencias de nuestros actos, esperando un cielo o un infierno según sea nuestro proceder en el paso por la vida terrena. 
En derecho, el concepto no difiere mucho, pues es la potestad reconocida o dada por el Ordenamiento para la autodeterminación de los intereses particulares, es decir, un ente superior nos concede o nos reconoce la potestad para disponer de nuestros propios intereses, sabiendo que si no lo hacemos bien o si no ejercemos la autonomía de forma responsable -y sobre este concepto quiero llamar la atención más adelante- nos enfrentamos a determinadas consecuencias.

El principio de autonomía de la voluntad privada es el poder reconocido por el ordenamiento, de autodeterminación de las personas. La facultad para disponer con efecto vinculante de los intereses y derechos de los que son titulares, siempre que se respete, la ley, el orden público y las buenas costumbres. (C 1194/08)

La autonomía de la voluntad, tal y como se conoce hoy en día, queda plasmada en los principios jurídicos del sistema liberal individualista, según el cual, las partes son los mejores garantes de sus propios intereses y el libre juego de las fuerzas económicas produce siempre lo mejor para los particulares. Es bajo este supuesto que los legisladores decimonónicos dieron a la mayoría de sus normas contractuales el carácter de derecho meramente dispositivo.

Es el reino del laisser faire, laisser passer, el principio rector de toda la actividad económica y se considera que la autonomía de la voluntad privada es el medio más efectivo para el establecimiento de relaciones jurídicas útiles y justas, reconociendo la plena eficacia jurídica a los actos y declaraciones que se realizan en la vida privada.

El sistema jurídico colombiano y particularmente lo atinente al derecho privado, y más particularmente, el derecho de contratos, como en el resto de los países de su entorno, nace inspirado en el sistema francés y recibe el legado de los principios allí consagrados: el individualismo, el li- 
beralismo clásico, la autonomía de la voluntad ${ }^{1}$, lo que se ha visto reflejado en la línea jurisprudencial que han seguido las distintas cortes.

Así por ejemplo, la Sentencia 1807-2015 aduce que "En virtud del postulado de la autonomía de la voluntad, pueden los particulares, siempre que no violen los límites del orden público, elegir las formas que consideren pertinentes para llevar a cabo sus designios". Por su parte la Sentencia C-993/2006 menciona que:

La garantía de las libertades del individuo es uno de los pilares de un Estado Social de Derecho (...) Dicha libertad se traduce en la facultad de aquel para autoregular su conducta en la vida social, reconocida por el ordenamiento jurídico, con sujeción a los límites impuestos por este, y que se denomina autonomía privada.

Y la Sentencia C-660-96 en igual sentido:

La segunda garantía constitucional en la cual se fundamentan las facultades del testador es la autonomía privada de la voluntad y aunque no existe una norma constitucional que la contemple en forma específica, ella se deduce de los artículos que consagran la libertad y el libre desarrollo de la personalidad.

Por su parte, la Constitución Política colombiana consagra la autonomía de la voluntad. No lo hace explícitamente, pero si mediante la garantía de las libertades del individuo, y así aparecen normas constitucionales que son garantes del ejercicio de la autonomía privada como las del

\footnotetext{
1. Alterini (2007) trae para nosotros un análisis que hizo Berthiau concluyendo que el sentido que debe dársele al postulado de eficacia normativa de los contratos, es más bien un principio de respeto que deben las partes a las convenciones mutuas como lo harían con una ley “a condición de que el procedimiento legal de formación del contrato haya sido a su vez respetado" y continúa: "lo cual es distinto que predicar que la voluntad tiene por sí misma aptitud para generar el contrato en los alcances que las partes decidan (...) la expresión hace referencia al procedimiento de formación del contrato" y siempre ha estado el principio de Autonomía de la Voluntad sujeto a las normas indisponibles o de orden público.
} 
artículo 16: “Todas las personas tienen derecho al libre desarrollo de su personalidad sin más limitaciones que las que le imponen el derecho de los demás y el orden público”, y sabemos que no hay más orden público que el derecho imperativo. El artículo 13 por su parte, preceptúa que "Todas las personas nacen libres e iguales ante la Ley (...) gozarán de las mismas libertades (...), el artículo 14 consagra el derecho a la personalidad jurídica, el artículo 38 el derecho a la libre asociación y el artículo 42 el derecho a unirse en matrimonio.

En derecho privado no podría entenderse la autonomía de la voluntad sino a la luz del artículo 1495 del Código Civil, que la consagra como una de las fuentes de las obligaciones, y del postulado de la normatividad de los actos jurídicos establecido en el artículo 1602, que ubica al contrato en la categoría de norma, tal como aquella que emana del órgano legislativo, en cuanto obliga a las partes intervinientes a cumplir con aquello declarado como si tuvieran que cumplir con una ley emanada del Estado, y así mismo da a la voluntad la potestad de declarar la invalidez de eso declarado. Es decir, el nacimiento y la extinción de las obligaciones contractuales depende del concurso real de las voluntades -cuando no de la leycuya declaración manifiesta se convierte en ley para las partes.

Así se configura la llamada libertad contractual, hija legítima de la autonomía de la voluntad, en cuyo ejercicio las personas se atan a determinadas acciones. En este sentido, libertad no es tanto para ser libre como para dejar de serlo y obligarse mediante vínculos jurídicos que emanan de la propia libertad ${ }^{2}$. Yo soy libre para dejar de ser libre obligándome frente a otros mediante la celebración de actos jurídicos (Díez- Picazo, Roca Trias, \& Morales, 2002) y es de interés público que los hombres puedan contratar libremente y que los contratos que hayan celebrado puedan ser ejecutados sin trabas (Alterini, 2007).

2. Recordemos aquella regla del derecho romano "el que es libre para querer, lo es también para no querer". 
Así pues, la libertad contractual se materializa en la libertad de contratar o no contratar, de elegir mi contraparte en un contrato, pero además, en la libertad para establecer el contenido del contrato, la regla negocial, ese conjunto de deberes, derechos y obligaciones que las partes según sus propios intereses estimen convenientes.

Los principios del Derecho Europeo de contratos, consagran en su artículo 1.102 la libertad de contratación como uno de los principios fundamentales del derecho contractual: "las partes son libres para celebrar un contrato y para determinar el contenido del mismo, siempre que se observen las exigencias de la buena fe y de la lealtad y las reglas imperativas establecidas en estos principios"; adicionalmente, permite a las partes, en el ejercicio de esa libertad, excluir la aplicación, derogar o modificar cualquier principio o efecto del principio cuando no se disponga lo contrario, establece como límites al ejercicio de esta libertad contractual, la buena fe y las normas de derecho imperativo.

De igual manera, los principios de UNIDROIT, establecen como principio básico la libertad de contratación en el comercio internacional, en el sentido del derecho de las personas a decidir libremente a quien ofrecerle sus bienes y servicios y de quien adquirir esos bienes, así como la posibilidad de acordar libremente los términos y condiciones de los acuerdos, su regla negocial, con excepción de aquellos sectores de la economía en los que el Estado debe intervenir en atención a la protección de intereses superiores, como es el caso de los servicios públicos domiciliarios. Establece como límites a esta libertad, aquellos que dentro de los mismos principios del derecho nacional de cada uno de los países, se consideran de derecho imperativo.

En la forma, la libertad contractual se traduce en el hecho de que, en principio, las personas pueden expresar su voluntad de contratar como a bien tengan -lo cual implica que solo se requerirán formalidades cuando 
la ley lo exija-, y en el fondo, en que las personas tienen la libertad de contratar o no hacerlo y en caso de que decidan concluir un contrato, lo pueden hacer como a bien tengan. (Cárdenas Mejía, 1999)

Pero debe tenerse en cuenta que la delimitación del contenido del contrato debe hacerse considerando no solo aquellas normas de tipo dispositivo, sino también la existencia de aquellas de derecho imperativo que son de ineludible cumplimiento, sobre las cuales, aun tratándose de la órbita del derecho privado, no cabe la libre disposición de las partes y sobre las que se establecen los llamados límites a la autonomía de la voluntad por tratarse de normas que protegen un interés general.

La idea de autonomía, según Ihering (citado por Alterini, 2007), estuvo "en la base del derecho privado antiguo, en el cual la lex pública no aporta restricciones al dominio de la legislación privada sino allí donde el interés de todos lo exige imperiosamente”.

En este orden de ideas, encontramos lo que la doctrina ha definido como limitaciones que son aquellas restricciones de tipo formal por las que las partes, por ejemplo, no pueden disponer algunos aspectos formales de la declaración de voluntad, como el nombre que le quieran dar al contrato, en cuanto faltan algunos elementos esenciales de tipo específico sin los cuales por más que se empeñen en definirlo como un tipo contractual nacerá como otro tipo contractual, así la compraventa no será compraventa sin un precio cierto y en dinero. Los límites en cambio constituyen la frontera de tipo sustancial, el techo hasta donde pueden llegar las partes y que les son impuestos por la ley para el ejercicio de la autonomía.

Hasta dónde les permite el ordenamiento disponer de sus intereses particulares sin que se vean afectados aquellos intereses considerados previamente como de orden público o bien común, y que puede ser interpretado de diversas formas, como bien social, o como protección de la mayor cantidad posible de intereses con el menor sacrificio (Cárdenas Mejía, 1999), 
son las normas, desde la constitución hasta aquellas leyes especiales de los contratos que subordinan la iniciativa privada al bien común; ejemplo de esto es el límite que impone el derecho colombiano a la libre disposición de sus bienes de un testador que debe forzosamente respetar los derechos de la descendencia ${ }^{3}$.

"En este sentido, los límites de la libertad contractual no operan como límites de la libertad de contratar o no contratar, sino más bien como límites de la libertad de determinación del contenido del contrato, así, puede existir contenido contractual" que no haya sido expresamente pactado por las partes pero que se derivan de la buena fe o del derecho imperativo (Díez- Picazo, Roca Trias, \& Morales, 2002), o por el contrario, habrá un contenido expresamente pactado y aceptado por las partes, pero cuya perfección de consentimiento será nulo por encontrarse claramente en contradicción con el principio de buena fe o con el derecho imperativo.

La buena fe ha sido consagrada en los ordenamientos jurídicos como uno de los principales límites a la autonomía de la voluntad, y en este sentido, las partes deberán aceptar que su declaración debe entenderse como la otra parte haya podido entenderla conforme la buena fe, esto es, lo que la doctrina ha llamado la interpretación integradora, de modo que del contrato se entiende todo aquello que pueda deducirse de su contexto de modo comprensible para las partes (Larenz, 2002).

En el ordenamiento colombiano, la autonomía se encuentra subordinada al orden público, cuyos principios prevalecerán siempre, en este sentido por ejemplo el artículo 16 CC: "No podrán derogarse por convenios particulares las leyes en cuya observancia están interesados el orden público y las buenas costumbres”, o el artículo 1518 que hace consistir el

\footnotetext{
3. El intercambio de bienes o servicios a través de los contratos, es decir el ejercicio de la libertad contractual será siempre más fácil cuando los derechos individuales que se acuerdan mutuamente se encuentran previamente definidos y no son arbitrarios, que además son derechos reconocidos por las partes incluso cuando estas partes no son iguales en algunas de sus condiciones personales, como las económicas y pueden sin embargo tratar con el otro de igual a igual en determinada transacción (Buchaman, 2009).
} 
objeto ilícito en el hecho prohibido por las leyes, o el que establece que todo contrato es ley para las partes y no puede ser convalidado sino por consentimiento mutuo o causas legales (Ospina Fernández, 2014, pág. 13).

Hay así mismo, distintas manifestaciones de estos límites que se incorporan en el ordenamiento sin aparecer explícitamente como tales, es el caso por ejemplo de las formalidades constitutivas de los actos jurídicos sin las cuales carecen de toda validez, o las normas que establecen los elementos esenciales sin los cuales no hay acto o deviene en otro tipo, así mismo las normas que establecen los efectos jurídicos de un negocio válido, entre otras (Bohórquez Orduz, 2009, pág. 47).

En tal sentido, la Sentencia SC 28 de julio de 2005 menciona que

Cierto que la autonomía de la voluntad continúa siendo uno de los soportes más salientes en la vida contractual de los individuos, pero ha tenido que resistir ciertos ajustes, todo lo más cuando de por medio hay un interés que trasciende la frontera de lo estrictamente privado, casos típicos del precio en el contrato de arrendamiento o en las ventas de mercaderías básicas de un conglomerado, y también cuando él resulta irrisorio o sumamente lesivo para uno de los celebrantes; lo propio sucede con la teoría de la imprevisión, para no citar sino unos cuantos ejemplos. Hay que convenir entonces que no es ya el principio arrollador de otrora.

\section{I.I Autonomía privada y condiciones generales de la contratación}

El derecho privado ha sufrido transformaciones sustanciales importantísimas y que difieren de aquel para el cual fue pensada la autonomía privada, en el que se establecía como una especie de voluntarismo jurídico. En 
este orden de ideas, han ido surgiendo límites impuestos por razones políticas, legislativas o incluso económicas, que den respuesta a estas transformaciones socio jurídicas. En consecuencia, se han establecido derechos que no son renunciables ni aun con el consentimiento de las partes, se pone precio a los medicamentos, a los arrendamientos, a los servicios públicos domiciliarios, etc.

El derecho contractual obviamente no ha quedado al margen de estas transformaciones jurídico sociales, en las que hoy se habla de autonomía de la voluntad en un contexto en el que las partes contratantes en una aparente desigualdad negocial ${ }^{4}$, mantienen su libertad contractual pero limitada a contratar o no contratar, más no para determinar el contenido regulatorio de sus contratos, es decir no ejercen dicha autonomía en el establecimiento de los derechos y las obligaciones que regularán dicha relación, ni el alcance de las mismas, como son los llamados contratos de adhesión.

Este tipo de contratación, en cuya proliferación el avance de la tecnología ha contribuido enormemente, da origen de la doctrina de las condiciones generales, que se conciben como ese cuerpo de cláusulas contractuales que se encuentran predispuestas por una de las partes para una pluralidad de contratos y con ello aparece el contrato en masa, cuyo esquema rompe el paradigma del contrato que tenía in mente la doctrina tradicional (Díez-Picazo, 1979).

Son innegables las ventajas que supone para la vida moderna y la racionalización del tráfico contractual la utilización de condiciones generales, particularmente cuando se utilizan en transacciones que deben realizarse

\footnotetext{
4. Mantenemos que la desigualdad no es algo que se encuentre del todo probado, o más bien, mientras haya leyes claras previamente establecidas en las cuales las partes puedan encontrar la protección de sus mutuos acuerdos, esta desigualdad jurídica tiende a desaparecer a pesar de la subsistencia de otro tipo de desigualdades, como la económica. Es lo que hace en sí mismo por ejemplo el control de incorporación al funcionar como garante del consentimiento contractual. Además, como hemos mencionado en otras ocasiones, refiere el profesor Alonso Pérez (2004), que la igualdad contractual estrictamente entendida como igualdad es una utopía, pues incluso desde el código decimonónico se trataba de la burguesía celebrando con la clase obrera.
} 
con celeridad a fin de obtener ciertos beneficios económicos (Lacayo, 2015) y sobre los cuales la negociación de cada una de las cláusulas representaría mayor onerosidad para las partes, no solo para los empresarios, sino incluso para aquellos adherentes que en su calidad de consumidores, deben actuar con diligencia y rapidez para obtener el mayor beneficio posible, tanto tratándose del poder adquisitivo como del mejoramiento de la calidad de vida con los bienes y servicios a los que pueden acceder gracias al ahorro que representa para los proveedores y productores, esta celeridad.

Ahora bien, en este sentido el primer planteamiento jurídico que se hace frente a la utilización de condiciones generales o de cláusulas incorporadas mediante condiciones generales, es el de la causa de la obligatoriedad de estos contratos. Si la causa de las obligaciones contractuales se encuentra en la declaración libre de voluntad, aquella sin la cual no se perfecciona el consentimiento, entonces en los contratos de adhesión no podría hablarse de esa causa, al entender la doctrina que no había declaración de voluntad alguna, pues la declaración de voluntad para una de las partes intervinientes en el contrato, se limitaba a contratar o no contratar, y a veces incluso movidos por un estado de necesidad en el que no existía otra posibilidad que la de contratar y verse sometido a unas condiciones generales de cuya realización no participó.

¿Cuál era entonces el fundamento de validez de esas condiciones generales, al no poder encontrarse en la voluntad de las partes?

Según la tesis normativista, la fuerza vinculante de las condiciones generales se encuentra en una especie de derecho normativo, similar al que se establece como derecho dispositivo y que pasa a formar parte del contrato con o sin la voluntad de las partes (Álfaro, 2002), afirmación que fue muy cuestionada en cuanto a que no existe una superioridad jurídica del predisponente que le haya merecido una delegación del poder normativo, exclusivo de los órganos de control estatal. 
Una doctrina, normativista también, pero menos radical, de las condiciones generales, considera que estas son una declaración unilateral de voluntad cuya fuerza vinculante para ambas partes depende de la aceptación de la parte que se adhiere a dicha declaración, aunque tampoco puede hablarse de contrato. Es requisito, para efectos de obligatoriedad de las condiciones generales, la adhesión, pero no puede esta equipararse en ningún sentido al consentimiento propiamente dicho, de hecho, para los doctrinarios defensores de esta postura la adhesión excluye el consentimiento.

La doctrina contractualista por su parte, reconoce que la única vía que faculta a los particulares para normar sus propias relaciones jurídico privadas es el ejercicio de la autonomía mediante las declaraciones libres de voluntad ${ }^{5}$, y solo son vinculantes por y para el contrato en que han sido aceptadas, pues antes de haberlo sido son solo oferta contractual, y una vez es aceptada se perfecciona el consentimiento (García Amigo, 1969). Adhesión se equipara a consentimiento, en cuanto a que por ambas formas, las partes quedan obligadas al cumplimiento del contrato (Martínez Martín, 1996).

El debate surgido sobre la utilización de las condiciones generales en los contratos trajo consigo la llamada "crisis" de la autonomía privada, o lo que muchos doctrinarios han llamado crisis del contrato, en el sentido de decadencia, inoperancia; "el contrato desaparece, perece, otra cosa se coloca en su lugar" dice Savatier, e incluso se llega a hablar de su muerte (Alterini, 2007). Lejos de la verdad, la autonomía de la voluntad nunca antes ha estado más en auge, o si se quiere más protegida, y si de alguna crisis puede hablarse es de la crisis del desgastado término crisis, más cuando vemos como el contrato moderno se reinventa para responder a las demandas de los tiempos y a las exigencias del tráfico contemporáneo (Jaramillo J, 2015).

.5 En este sentido se ha pronunciado la Corte Constitucional colombiana en Sentencia C 1194-08, "El principio de autonomía de la voluntad privada ha sido definido como el poder de las personas, reconocido por el ordenamiento positivo para disponer con efecto vinculante de los intereses y derechos de los que son titulares y por ende crear derechos y obligaciones, siempre que respete el orden público y las buenas costumbres”. 
Y esta "crisis" no hace más que reafirmar la supremacía del contrato como el medio por excelencia para la ejercicio de la autonomía de la voluntad, como la herramienta que el ordenamiento pone a disposición de los sujetos para la libre disposición de sus derechos, incluso en el contrato de adhesión, aquel al que una parte se adhiere y que puede contener condiciones particulares -negociadas o no, se establecen particularmente para el contrato en mención- o en el de las condiciones generales que hacen parte del contrato de adhesión y que no siempre se encuentran incorporadas en el contrato, a veces simplemente se refiere a ellas, haciendo la referencia expresa a otro documento o un lugar que en el momento de celebración del contrato no se encuentra a disposición del adherente.

Ahora bien, cabría preguntarse si los límites que tiene el adherente en el ejercicio de su libertad contractual en cuanto a su poder de negociación pueden dar cuenta de una crisis de la autonomía de la voluntad. Los límites a los cuales se encuentra sujeta la autonomía hoy en día, se fundamentan en el respeto y la garantía de la misma y de la protección de los intereses particulares. Una ley que establece cláusulas abusivas, no lo hace en virtud de intervenir en el contenido porque si, sino en función de garantizar que lo pactado en los contratos sea producto de la voluntad de las partes, y como esa voluntad no se puede descubrir en ciertas cláusulas que son predispuestas y que resultan ante el derecho, desequilibradas, el ordenamiento las presume abusivas, para evitar a su vez el abuso del ejercicio de esa autonomía.

Si en el contrato negociado la autonomía de la voluntad encuentra sus límites en el orden público, en el contrato de adhesión -al menos en los contratos de adhesión cuando el adherente es un consumidor- los límites están dados por el control del contenido: que se configura mediante un criterio general por una parte, y por otra, en una lista de cláusulas abusivas.

La doctrina de las cláusulas abusivas en sí misma, constituye un límite a la autonomía de la voluntad, aunque las partes sean libres para es- 
tablecer el contenido de sus relaciones contractuales; esta facultad no puede servir para la obtención de un beneficio injustificado mediante la imposición de una cláusula contractual, en tal caso, la figura de las cláusulas abusivas aparece como instrumento idóneo para remediar esto. (Rodríguez Yong, 2013)

\section{Protección a la autonomía privada en el derecho de consumo}

Esta situación es aún más crítica cuando además de condiciones generales y contratos de adhesión, estas se presentan en contratos celebrados en el ámbito de una relación de consumo. Los consumidores han sido considerados por la doctrina y por la norma la parte débil de la relación contractual, su estado de necesidad los ubica en una posición desventajosa con relación a su contraparte empresaria. La misma constitución colombiana ha consagrado la protección especial a las personas que pos su condición económica se encuentre en circunstancia de debilidad manifiesta.

La debilidad económica no ha sido consagrada como un vicio del consentimiento en el ordenamiento colombiano, y es por eso que la lesión enorme en los contratos solo puede ser causa de rescisión en algunos tipos contractuales previamente establecidos por el código civil, como la compraventa y permuta de bienes inmuebles.

Ha sido la doctrina la que ha puesto sobre la mesa la posibilidad de decretar la nulidad absoluta por objeto ilícito de un contrato abusivo, en cuanto contraviene el artículo 1519 del Código Civil, aunque admitiendo que si la nulidad absoluta se funda en la existencia de consideraciones de interés público, no podría ¿actuar? en el caso que nos ocupa, pues se trata de la protección de los intereses particulares, (Cárdenas Mejía, 1999). Para dar por válido este argumento hay que considerar que la norma sobre protección de los consumidores ha sido catalogada de orden público, con lo 
cual se entiende que la protección de los intereses de los consumidores es de orden público.

Es el Estatuto del Consumidor, el que ha establecido el marco de protección que en sede de consumo se establece respecto a la celebración de contratos con condiciones generales.

Primero, se establece la definición de consumidor:

Toda persona natural o jurídica que, como destinatario final, adquiera, disfrute o utilice un determinado producto, cualquiera que sea su naturaleza para la satisfacción de una necesidad propia, privada, familiar o doméstica y empresarial cuando no esté ligada intrínsecamente a su actividad económica. Se entenderá incluido en el concepto de consumidor el de usuario. (Arto. 5.3 Ley 1480)

Adicionalmente se consagra como principio rector del derecho de consumo la protección, promoción y garantía del libre ejercicio de los derechos de los consumidores, entre esos el derecho al respeto de sus intereses económicos y a la elección libre de los bienes y servicios que requieran. La norma no considera por tanto que el consumidor actúe en un estado de necesidad.

También se definen los contratos de adhesión como aquellos en los que las cláusulas son dispuestas por el productor o proveedor, de manera que el consumidor no puede modificarlas, ni puede hacer otra cosa que aceptarlas o rechazarlas.

Siguiendo el sentido de la ley, las cláusulas de los contratos de adhesión son las cláusulas predispuestas por una de las partes a las cuales la otra parte se tiene que adherir, son cláusulas reguladoras de la materia contractual, preformuladas y concebida con caracteres de generalidad, abstracción, uniformidad y tipicidad, determinando una pluralidad de relaciones. 
Otro aspecto importante a considerar es el de derecho de retracto que contiene el estatuto del consumidor ante aquellos contratos en los que el consumidor no haya tenido acceso al bien o servicio al momento de perfección, en cuanto se ha estimado aconsejable que el consumidor pueda replantearse aún después de perfeccionarse la venta, su decisión o aceptación en virtud de la insatisfacción o efecto sorpresivo que le pueda generar el contrato (Jaramillo J, 2015)

Así mismo, la ley ha consagrado dos controles mediante los cuales se protege la autonomía de la voluntad, por una parte, un control sustancial o de contenido del contrato con el propósito de prevenir la inclusión de cláusulas desequilibradas que representen un desequilibrio importante en perjuicio del consumidor, limitando claramente con esto el ejercicio de la autonomía de la voluntad en procura del respeto de la misma autonomía. Y por otra parte, aunque dándole quizás un poco menos de importancia que al control del contenido, un control formal que garantice la formación del consentimiento a través del conocimiento oportuno de las condiciones generales, con esto sí, garantizando que las partes actúan en ejercicio de su propia autonomía.

\section{I El control del contenido en los contratos de adhesión}

Como bien se ha señalado (Bohórquez Orduz, 2009), la ley no determina el contenido particular de cada negocio jurídico, sino que fija previamente reglas generales que unas veces las partes pueden incorporar a sus contratos y otras deben necesariamente incorporar, y por lo tanto delega la responsabilidad de establecer el contenido regulatorio de sus relaciones a las partes contractuales, en uso de sus facultades derivadas del principio de la autonomía de la voluntad, considerando únicamente cuando están en facultad de prescindir de las reglas establecidas por las leyes y cuando deben tenerlas por imperativas. 
En la protección de los consumidores, la Ley 1480, ha incorporado un control llamado control del contenido de naturaleza normativa y jurídica, que limita en cierto sentido, lo que las partes pueden o no pueden disponer en el contrato como contenido regulador del mismo, al mejor estilo de las Directivas comunitarias europeas y las leyes internas de los países pioneros, incorpora una doble fórmula de control, por una parte, establece una cláusula general que ofrece al juzgador los criterios para determinar en qué casos y según qué circunstancias y naturaleza del contrato, una cláusula puede ser abusiva o no, pudiendo serlo en algunos casos y en otros simplemente ser una cláusula válida.

Los criterios por los cuales se puede determinar esta abusividad son los de (1) desequilibrio injustificado, (2) en perjuicio del consumidor, agregando además el agravante para aquellas cláusulas que además de cumplir con estas condiciones, afecten el tiempo, modo y lugar en que el consumidor puede ejercer sus derechos.

\subsection{El concepto de cláusula abusiva y cláusula prohibida}

Cláusula abusiva, dice el estatuto, es aquella "que produce un desequilibrio injustificado en perjuicio del consumidor" y las que, además de producir este desequilibrio afectan el modo, tiempo y lugar en que el consumidor puede ejercer sus derechos. Concepto que sigue los lineamientos de la doctrina colombiana en cuanto supone que cláusulas abusivas son aquellas que "conceden una ventaja o imponen una carga excesivamente intolerada a favor o en contra de una de las partes".

Siendo que se trata de un régimen tan especial como el de consumidores, habría que preguntarse si el equilibrio al que se refiere el estatuto es también el equilibrio económico, de ser así, el problema surge en cuanto que el ordenamiento colombiano no admite la rescisión por lesión enorme, como ya vimos, sino en muy pocos casos y los consumidores no cuentan con las herramientas para restituir ese equilibrio. 
Desde la perspectiva del ordenamiento colombiano, y desde el sistema de economía liberal, en el que este se fragua, debe entenderse que el desequilibrio al que se refiere esta ley es el contractual o normativo, el concerniente a las respectivas posiciones jurídicas, es decir, al que coloca al consumidor en situación de mayor onerosidad ante su contraparte, en un estado de indefensión tan importante que la mayoría de las obligaciones contractuales resultan a su cargo, o que los derechos que de ordinario le otorga el tipo contractual le sean arrebatados por la predisposición e imposición del predisponente.

Se adiciona al desequilibrio, el de "injustificado", en cuanto no haya asidero en el ordenamiento para incluir dicha carga o excluir tal derecho en un contrato, sea por la propia naturaleza del contrato, o sea, por las ventajas que el consumidor recibirá a cambio, en cuyo caso, es el juez quien determina si la cláusula puede ser abusiva de conformidad con las específicas condiciones de celebración.

El otro criterio que ofrece el legislador a la labor integradora del juzgador es el de "perjuicio al consumidor". Tanto el ordenamiento colombiano, como las Cortes nacionales en reiteradas ocasiones y como orientación jurisprudencial, han mantenido el principio de que nadie puede alegar a su favor su propia culpa $a^{6}$. En virtud de dicho principio, la Ley 1480 es clara en establecer que las condiciones generales serán abusivas siempre que el desequilibrio injustificado cause un perjuicio a quien se adhiere a dichas condiciones generales, es decir a quien no ha participado de su redacción, en coherencia además con la regla de interpretación contractual pro-adherente establecida en el mismo cuerpo legal. No puede admitirse que quien haya redactado las cláusulas que posteriormente se consideren abusivas, pueda alegar dicha abusividad para su propio beneficio.

6. Sentencia Corte Constitucional T-213/08, C-083/95, T-1231/08. 
Paralelo a este concepto se establece otro que cumple a todas luces con los criterios establecidos para las cláusulas abusivas, y no entendemos por qué el legislador ha regulado de forma separada dos conceptos que pueden caber uno dentro del otro. Aquellas cláusulas que permitan al productor o proveedor modificar unilateralmente el contrato o sustraerse de sus obligaciones, lo cual cabe perfectamente en el concepto de abusividad.

\subsection{La Lista de cláusulas abusivas}

Junto al criterio general de abusividad, la ley incorpora una lista de cláusulas abusivas de pleno derecho, cláusulas que quedan excluidas de todo contrato celebrado con consumidores sin el ejercicio de revisión ni labor integradora de un juez, y tampoco lo son atendiendo a las circunstancias de celebración del contrato o a la naturaleza del mismo.

La lista enumera catorce cláusulas que son ineficaces de pleno derecho, es decir que su inclusión no queda al arbitrio del empresario ni su declaración de abusivas al criterio del juzgador, son cláusulas que no admiten matices ni interpretación, razón por la cual la doctrina extranjera la ha llamado lista "negra”. Así, son consideradas previamente como ineficaces de pleno derecho aquellas cláusulas que:

1. Limiten la responsabilidad del productor o proveedor de las obligaciones que por ley les corresponden;

2. Impliquen renuncia de los derechos del consumidor que por ley le corresponden;

3. Inviertan la carga de la prueba en perjuicio del consumidor;

4. Trasladen al consumidor o un tercero, que no sea parte del contrato. la responsabilidad del productor o proveedor;

5. Establezcan que el productor o proveedor no reintegre lo pagado si no se ejecuta en todo o en parte el objeto contratado;

6. Vinculen al consumidor al contrato, aun cuando el productor o proveedor no cumpla sus obligaciones; 
7. Concedan al productor o proveedor la facultad de determinar unilateralmente si el objeto y la ejecución del contrato se ajusta a lo estipulado en el mismo;

8. Impidan al consumidor resolver el contrato en caso de que resulte procedente excepcionar el incumplimiento del productor o proveedor, salvo en el caso del arrendamiento financiero;

9. Presuman cualquier manifestación de voluntad del consumidor, cuando de esta se deriven erogaciones u obligaciones a su cargo;

10. Incluyan el pago de intereses no autorizados legalmente, sin perjuicio de la eventual responsabilidad penal;

11. Para la terminación del contrato impongan al consumidor mayores requisitos a los solicitados al momento de la celebración del mismo, o que impongan mayores cargas a las legalmente establecidas cuando estas existan;

12. ¿Lo que? ha sido derogado por el artículo 118 de la Ley 1563 de 2012.

13. Restrinjan o eliminen la facultad del usuario del bien para hacer efectivas directamente ante el productor y/o proveedor las garantías a que hace referencia la presente ley, en los contratos de arrendamiento financiero y arrendamiento de bienes muebles.

14. Cláusulas de renovación automática que impidan al consumidor dar por terminado el contrato en cualquier momento o que imponga sanciones por la terminación anticipada, a excepción de lo contemplado en el artículo 41 de la presente ley.

En cuanto al ordenamiento sectorial, múltiples normas han incorporado sus propias listas, así por ejemplo,, el consumidor financiero, se encuentra protegido por un ordenamiento especial propio del sector, que incluye una lista de cláusulas abusivas que también se consideran ineficaces de pleno derecho. Estas se encuentran contenidas en el estatuto del consumidor financiero, Ley 1328 de 2009. 


\subsection{El control formal de las Condiciones Generales}

La autonomía de la voluntad continúa siendo la causa o el fundamento de validez de las condiciones generales, su aceptación -o adhesión, que viene siendo lo mismo- no puede entenderse sino en el ejercicio de la autonomía. La doctrina ha considerado que el control de incorporación funciona de garante de dicha autonomía a pesar de las particulares condiciones en las que se celebran los contratos con condiciones generales, en cuanto solo aquellas condiciones generales que han sido incorporadas al contrato, forman parte de él, es decir, solo aquellas que han sido previamente conocidas y presumiblemente aceptadas, son parte del contenido del contrato, lo que soporta en conclusión, el carácter contractual de las condiciones generales (Pagador López, 1999). Se le ha dado al control de incorporación la función de facilitar al adherente el conocimiento y la comprensión del alcance de las condiciones generales, así como la de publicidad de las mismas (Embid Irujo, 2002).

El control formal o control de incorporación de las condiciones generales constituye una concreción del deber de buena fe, exigido a los contratantes en la fase prenegocial de cualquier contrato (Llodrá Grimalt, 2002), que se materializa en aquellos requisitos formales que deben cumplir las partes al incorporar sus cláusulas, para que estas puedan considerarse parte del contenido contractual legalmente válido, esto es, los requisitos de forma, tiempo y lugar en que el predisponente ha informado a su adherente el contenido previamente establecido por él.

Con esto se supone, que una cláusula que ha sido incorporada en unas condiciones generales no se considera parte del mismo hasta tanto no se confirme que se han cumplido dichos requisitos.

Aunque este control no se encuentra concretamente configurado como tal en la Ley 1480, como en otras legislaciones que si la incorporan directamente, sí se vislumbra en el deber de información que se exige sea 
dado por quien redactó las cláusulas a quien se pretende vincular al contrato. Porque el control de incorporación o control formal, no es más que control de información del contenido, no ya en cuanto a su abusividad o al desequilibrio que pueda contener una cláusula o el perjuicio que pueda producir a una de las partes, sino cómo, cuándo y dónde ha sido esa cláusula informada al contratante que no ha participado de su redacción.

Es así que la ley primero exige que la información sea "suficiente, anticipada y expresa", no solo en cuanto a la existencia de las condiciones generales, sino también a sus efectos y alcances. De un lado tenemos que la información debe ser suficiente, amplia y completa de acuerdo a la naturaleza del contrato que debe contener todos los elementos propios, de otro lado, la información debe ser anticipada para que pueda darse por conocido aquello que se consintió.

Este deber de información previa, encuentra justificación en cuanto las condiciones generales -no negociadas y desconocidas- pueden contener, como efectivamente contienen, cláusulas determinantes para la celebración del contrato sobre las cuales es necesario tener un conocimiento con anticipación que permita realizar la comparación necesaria entre las ofertas que encuentra el consumidor en el mercado.

Otro aspecto a considerar en el tema de información debida es el de las cláusulas sorprendentes, aquellas que no son abusivas en sí mismas por su contenido y no son intrínsecamente desequilibradas, pero que por inesperadas pueden producir un perjuicio importante en un contratante que no ha sido informado previamente de su existencia, sea porque no son propias a la naturaleza del contrato celebrado o porque no es usual que sean incorporadas a los mismos.

Estas cláusulas, a la larga se considerarán abusivas, pero no ya por su contenido, sino por la falta de información debida que es una obligación 
que emana de la buena fe. Todo aquello que contraríe la buena fe debe ser considerado abusivo (Gozálvez, 1992).

\subsection{La Interpretación y la Integración de las Condiciones Generales}

El principio de la autonomía de la voluntad se ha incorporado también a las reglas de interpretación de las cláusulas contractuales, así, el artículo 1618 de Código Civil, establece la regla de la prevalencia de la voluntad sobre lo declarado que busca el respeto por la verdadera intención de las partes, así no se haya plasmado en ese sentido: "conocida claramente la intención de los contratantes, deberá estarse a ella más que a lo literal de las palabras”.

Es esta la regla por excelencia en la interpretación de los contratos; de manera subsidiaria, cuando no sea posible encontrar la verdadera intención, se atendrá a otras reglas como la de interpretación sistemática o la regla de la prevalencia de la validez sobre la nulidad.

En los contratos con condiciones generales con consumidores, dadas las circunstancias particulares de celebración y de perfección del consentimiento, se ha entendido que el contenido de las cláusulas no plasma la verdadera intención o voluntad de ambas partes, en cuanto una sola es la que redacta y la otra se adhiere y acepta lo que previamente se ha dispuesto.

El derecho civil colombiano prevé también como regla subsidiaria el principio de interpretación pro-debitoris, en este sentido, el Estatuto del Consumidor ha consagrado esta interpretación favorable o pro-adherente como regla general para los contratos con consumidores; sin embargo, su finalidad está limitada por el concepto de “más favorable al consumidor”, dejando al margen la aplicación de la regla contra-stipulatorem, sabiendo con toda certeza que se trata de contratos en los que una parte es la que predispone las cláusulas y la otra, la que se adhiere. 
La interpretación favorable debe hacerse por vía integradora en dos sentidos

1. Si una misma cláusula puede ser interpretada en dos sentidos, uno que favorezca al consumidor y otro que le afecte, será interpretada siempre en su favor

2. Si una cláusula es clara, pero otra cláusula también clara, la contradice, se establece la regla de la prevalencia de la cláusula que favorezca al consumidor sobre la que lo afecte.

De igual manera el Estatuto consagra una regla de "prevalencia” en el mismo sentido que la regla de interpretación, es decir, en beneficio del consumidor, así, una cláusula que en su sentido individual pueda ser clara, pero contradictoria y dudosa frente a otra cláusula del mismo contenido de condiciones generales, solo será incorporada cuando favorezca sobre la otra al consumidor y omite la que le perjudique. Contrario a lo que se persigue en el régimen común que es la búsqueda del verdadero sentido y voluntad de las partes, en el régimen de los consumidores esa voluntad no puede llegar ni a presumirse, por ello, el legislador no deja abierta esa posibilidad y establece a priori que no interesa cual haya sido la voluntad. Por su carácter de reconocida debilidad, son los consumidores los protegidos.

Esta contradicción puede ser evidente: basta que la cláusula conduzca a una modificación de los derechos y obligaciones recogidos en el acuerdo individual o en otra cláusula general en perjuicio del consumidor. Ahora bien, al tenor literal debe entenderse que la interpretación de una cláusula o la prevalencia en caso de contradicción entre dos cláusulas, deben conducir necesariamente a un beneficio del consumidor.

No obstante, a la luz del mismo cuerpo normativo, y en aras de proteger el principio de autonomía de la voluntad, inherente también al derecho de los consumidores, y el principio de subsistencia del acto, según el cual, en la medida en que un contrato pueda subsistir sin las cláusulas nu- 
las o ineficaces, que no afectan su validez, debe entenderse en sede interpretativa, que basta que una cláusula pueda ser entendida en el sentido de que no perjudique al consumidor, o que de la contradicción entre dos cláusulas una lo perjudica y la otra no, para que prevalezca esta última.

En sede integradora, salvo por la facultad concedida expresamente a la autoridad competente de aclarar o rediseñar el contrato con los derechos y obligaciones que se deriven del acto subsistente, nada dice de las reglas que deben seguirse, por lo que podríamos pensar que implícitamente se remite a las reglas generales de recomposición de los actos jurídicos, considerando entre otros factores, los propios del tráfico de los consumidores como el equilibrio, los usos del comercio, la normas específicas como el Estatuto del Consumidor, y las generales como el Código de Comercio y el Código Civil. 


\section{Conclusiones}

El ordenamiento colombiano establece que el consentimiento se forma con el concurso real de las voluntades de dos o más personas, y el código de comercio establece que la oferta debe ser aceptada mediante adhesión simple y llana, mientras que cualquier modificación que se haga constituye una nueva oferta de contrato, más no perfección del consentimiento.

En este sentido puede decirse que la adhesión en Colombia sí perfecciona el consentimiento, y por tanto, no cabe duda que al igual que en los contratos negociados, la aceptación, previo conocimiento de las cláusulas de los contratos con condiciones generales, obliga a las partes a su cumplimiento.

Partiendo de esa idea, no solo nos encontramos ante actos jurídicos a los cuáles no puede discutirse su naturaleza contractual en ningún sentido, sino que además no puede cuestionarse el ejercicio de la autonomía de la voluntad ni el de la libertad contractual, cuyos límites se encuentran justificados, en cuanto implican la protección de los derechos y la garantía de los deberes, que contraen las partes mutuamente. 
En cuanto a protección del consumidor, el legislador colombiano no puede desatender el hecho de que es el consentimiento el que forma el contrato; en tal sentido, el control de forma materializado en los deberes relativos a la información contractual, constituye una herramienta fundamental para garantizar que el único poder normativo que tienen las partes como individuos siga siendo el de la autonomía de la voluntad, y que no basta la aceptación de las condiciones generales para que se considere existente el contrato, sino que precisa el conocimiento de esas cláusulas que han sido aceptadas, bajo la premisa de que nadie puede consentir lo que no conoce.

Por su parte, el control de fondo o de contenido constituye uno de los principales límites que se ponen al ejercicio de la autonomía en sede de condiciones generales, en cuanto queda prohibido para las partes incorporar cláusulas con contenido que sea considerado abusivo, según los criterios que la ley establezca, declarando por su parte la nulidad de pleno derecho y trastocando además el régimen común de las nulidades del derecho civil colombiano.

Las cláusulas que en un contrato negociado serían válidas, serán nulas de pleno derecho en un contrato con consumidores, y no podrán ni por voluntad declarada de las partes incorporarse a dichos contratos, dado que encierran en cierto modo derechos irrenunciables que se han establecido en virtud de una consideración de debilidad de la parte contratante cuando actúa en su calidad de consumidor.

Ahora bien, ¿podrá seguirse cuestionando el ejercicio libre de la autonomía de la voluntad en cuanto a la adhesión y en función de eso establecer límites que traspasen las fronteras de lo privado? ¿Es cierto que las formas de poder espontáneas no garantizan el cumplimiento del comportamiento debido derivado de la buena fe y por ello se hace necesaria la implementación de un modelo de justicia contractual distributiva derivada de la intervención del poder estatal? Tal como lo ha analizado alguna parte de la doctrina. 
En sede de los contratos celebrados con consumidores, hay intereses de orden público que justifican que se impongan límites al ejercicio indiscriminado de la autonomía, pero más que nada en función de la protección del contrato mismo, de la figura jurídica como tal y de su supervivencia, de su vigencia en el mundo moderno, con los cambios y las exigencias que demanden las nuevas formas de intercambiar bienes y servicios.

Mientras no se pierda de vista que la autonomía de la voluntad sigue siendo el único poder normativo que tienen las partes y la única fuente para quedar obligados ante otros, como si de una ley se tratara, los adherentes, sean consumidores o no, seguirán gozando de protección adecuada para la libre determinación de sus relaciones jurídicas. 


\section{Referencias}

Álfaro, Á. R. (2002). Función Económica y naturaleza jurídica de las condiciones generales. En M. M. Díez-Picazo, Comentarios a la Ley sobre condiciones generales de la contratación (pp.. 81-xx). Madrid: Civitas.

Alonso Pérez, M. (2004). Aproximaciones a la idea de contrato (Apoteosis y declive de la autonomía privada). Responsa Iurisperitorum Digesta. Alterini, A. (2007). Estudios en Derecho Civil: Conceptos, contraos, consumidor, derecho. Buenos Aires: La Ley.

Bohórquez Orduz, A. (2009). De los negocios jurídicos en el derecho privado colombiano. Bogotá: Ediciones Doctrina y Ley.

Buchaman, J. M. (2009). Los limites de la libertad, entre la anarquía y el leviatán. Madrid: Katz Editores.

Cárdenas Mejía, J. P. (1999). Justicia Contractual. En M. e. Plazas Vega, Derecho Civil y Comercial (pp.. 301-xx). Bogotá: Ediciones Rosaristas, Dike.

Díez-Picazo, L. (1979). Derecho y Masificación social, Tecnología y Derecho Privado. Madrid: Civitas.

Díez-Picazo, L., Roca Trias, E., \& Morales, A. (2002). Los principios del Derecho Europeo de Contratos. Madrid: Civitas.

Embid Irujo, J. M. (2002). Comentarios a la Ley de Contratos de Seguro. Valencia: Tirant lo Blanch.

García Amigo, M. (1969). Condiciones Generales de los Contratos. Revista de Derecho Privado, volumen (número), 160-xx

Gozálvez, C. (1992). En B. Rodríguez-Cano, Comentarios a la Ley General para la defensa de los consumidores y usuarios. Madrid: Civitas.

Jaramillo J, C. I. (2015). La Compraventa en el Derecho de Consumo. Bogotá: Ibañez. 
Lacayo, M. A. (2015). Condiciones Generales de la Contratación, una perspectiva de la buena fe en el control de incorporación. Bogotá: Ibañez.

Larenz, K. (2002). Base del negocio jurídico y cumplimiento de los contratos. Granada: Comares.

Llodrá Grimalt, F. (2002). El contrato celebrado bajo condiciones generales. Valencia: Tirant lo Blanch.

Martínez Martín, M. (1996). Comentarios a la Sentencia de 13 de noviembre de 1995. ADC No. 41, 596.

Ospina Fernández, G. (2014). Teoría General del Contrato y del Negocio Jurídico. Bogotá: Temis.

Pagador López, J. (1999). Las condiciones generales de la contratación: introducción y régimen jurídico de los contratos celebrados mediante ellas. En G. Botana, \& M. Ruiz, Curso sobre protección jurídica de los consumidores (pp. xx-xx). Madrid: McGraw Hill.

Rodríguez Yong, C. A. (2013). Una aproximación a las cláusulas abusivas. Bogotá: Legis.

Valencia Zea, A. (1983). Derecho Civil, Tomo III, Obligaciones. Bogotá: Temis. 



\section{II. \\ LA RELACIÓN CONSUMIDOR, DISTRIBUIDOR Y PROVEEDOR BAJO EL ESTATUTO DEL CONSUMIDOR \\ Carlos Arturo Hernandez Díaz carlos.hernandez@ugc.edu.co}



Resumen. La protección al consumidor se encuentra latente en los estados de derecho, y el ordenamiento jurídico consagra disposiciones constitucionales y legales que la garantizan. El tema central de este capítulo se funda en las disposiciones de orden normativo que consagran la responsabilidad del productor y distribuidor y los derechos de los consumidores.

A partir del siguiente interrogante: ¿Cuáles son los aspectos de especial interés de la Ley 1480 en el marco de la responsabilidad del productor o distribuidor de bienes y servicios, conforme a la protección establecida por el legislador a favor del consumidor en Colombia? Con una estrategia metodológica explorativa- explicativa y a partir del método cualitativo, se abordara la legislación en la materia.

Palabras clave. Consumidor, distribuidor, responsabilidad, productor.

\section{Introducción}

Antes de analizar en detalle la Ley 1480 (2011) resulta pertinente conocer los antecedentes y el contexto en el cual dicha norma se desarrolla. Para empezar debe mencionarse la Ley 73 (1981) cuyo objeto consistió en la intervención estatal de la distribución de bienes y servicios y que fue conocida como la Ley del Consumo. En desarrollo de esta normativa se expidieron los Decretos 1441 y 3466 por los cuales se regula la organización, el reconocimiento y el régimen de control y vigilancia de las ligas y asociaciones de consumidores, y se dictan normas relativas a la idoneidad, la calidad, las garantías, las marcas, las leyendas, las propagandas y la fijación pública de precios de bienes y servicios, y la responsabilidad de los productores, expendedores y proveedores. Cabe resaltar que el Decreto 3466 (1982) es el anterior Estatuto del Consumidor. No obstante las trasformaciones sociales y jurídicas, en particular la relacionadas con el texto constitucional, llevaron a repensar las disposiciones del derecho al consumo para adaptarlas a la realidad y los derechos consagrados en el texto fundamental, aunado a la necesidad de adecuarse a la evolución 
mundial en el tema del consumo y la especial protección que gira, hoy en día, en torno al consumidor.

Como bien se señala en la ponencia de segundo debate al proyecto de Ley 252 de 2011, Senado, 089 de 2010, Cámara que dio lugar a la actual normatividad, el país no puede "ser ajeno a los cambios que han intentado establecer entre consumidores y proveedores para buscar relaciones más equilibradas, generar un marco de respeto mutuo, aumentar el crecimiento del mercado y beneficiar con su actividad y desarrollo a la comunidad

El esfuerzo por la legislación que regula el derecho al consumo, se remonta a dos décadas atrás, partiendo del proyecto presentado en 1993 sobre el Estatuto del Consumidor y de los Usuarios Públicos, presentado por Yolima Espinosa, Representante liberal del Valle.

Otro tanto, se hizo en el proyecto de Ley número 115 del 14 de noviembre de 2000 Cámara, por la cual se expide el Estatuto de Defensa del Consumidor, que surtió su trámite solo en la Cámara de Representantes. Posteriormente y con la finalidad de actualizar las normas en la materia, se presentó el Proyecto de Ley número 82 de 2008 Senado, por medio de la cual se actualiza el Decreto 3466 de 1982 y se dictan otras disposiciones.

La normatividad objeto de estudio en este capítulo es el resultado de 4 años de trabajo conjunto entre la academia, los gremios, el gobierno y los consumidores (Ponencia segundo debate proyecto de Ley 252 de 2011. Senado, 089 de 2010). Le correspondió a la Comisión Tercera del Senado su discusión y concertación en audiencia pública con participación del sector público y privado.

A partir de un estudio exploratorio- explicativo y cualitativo se presentó como eje problémico el siguiente: ¿Cuáles son los aspectos de especial interés de la Ley 1480 en el marco de la responsabilidad del productor o distribuidor de bienes y servicios, conforme a la protección establecida por el legislador a favor 
del consumidor en Colombia? Mediante una hipótesis afirmativa se pretende demostrar en los párrafos siguientes que la nueva normatividad se adapta de manera integra a un mercado de bienes y servicios cada día más complejo y con mayores derechos que proteger, con una amplia gama de deberes, obligaciones y prohibiciones en la relación contractual y la responsabilidad que de ella se deriva.

\section{El Estatuto del Consumidor y su armonización con el or- den jurídico colombiano}

Es el artículo 78 de la Constitución Política el eje rector para la regulación de la calidad de los bienes y servicios ofrecidos y prestados a la comunidad, al igual que la información que debe suministrarse al público en su comercialización en su amplio panorama, señala la responsabilidad de quienes producen y comercializan bienes y servicios, cuando al hacerlo atenten contra la seguridad, la salud y el adecuado aprovisionamiento a consumidores y clientes. Como lo ha señalado la Corte Constitucional (2000), lo que se busca con esta norma es proteger la posición de desigualdad que existe en el mercado entre el consumidor o cliente, y aquel que produce y comercializa bienes y servicios, lo cual lleva a que deban responder quienes se encuentran en las primeras fases del consumo, como son el productor, fabricante, o distribuidor, quienes se benefician del mercado, como lo señala Anaya (2012).

La Corte Constitucional ha considerado que la responsabilidad de que trata la norma arriba mencionada, busca proteger al consumidor frente a quien tiene el control de la producción y de la comercialización por no tomar las medidas necesarias o permitir la circulación de un producto o servicio defectuoso (Corte Constitucional, 2002).

En desarrollo de esa norma constitucional, la Ley 1480 (2011) define como consumidor o usuario a toda persona natural o jurídica que, como destinatario final, adquiera, disfrute o utilice un determinado producto, cualquiera que sea su naturaleza, para la satisfacción de una necesidad propia, privada, 
familiar o doméstica y empresarial, cuando no esté ligada intrínsecamente a su actividad económica.

En cuanto a la responsabilidad señalada por este Estatuto, en el artículo 20 se establece que:

(...) el productor y el expendedor serán solidariamente responsables de los daños causados por los defectos de sus productos, sin perjuicio de las acciones de repetición a que haya lugar. Para efectos de este artículo, cuando no se indique expresamente quién es el productor, se presumirá como tal a quien coloque su nombre, marca o cualquier otro signo o distintivo en el producto. (Ley 1480 de 2011 articulo 20)

Así mismo el artículo 21 señala que la responsabilidad se establece solo con la demostración del defecto del bien, la existencia del daño y el nexo causal entre ambos.

Los conceptos de idoneidad y calidad son definidos por el artículo $5^{\circ}$ de la Ley 1480 de 2011 en los siguientes términos:

- Idoneidad o eficiencia. Aptitud del producto para satisfacer la necesidad o necesidades para las cuales ha sido producido o comercializado.

- Calidad. Condición que un producto cumple con las características inherentes y las atribuidas por la información que se suministre sobre él.

Como se observa, la relación entre el productor y el consumidor está estrechamente regida por la responsabilidad, dado que el comprador presume de buena fe que el producto o servicio que está adquiriendo satisface adecuadamente la necesidad que él busca resolver y para lo cual entrega a cambio una determinada suma de dinero. Por esa razón, antes de entrar en el análisis 
detallado de la Ley 1480 resulta necesario conocer el desarrollo legal que tiene el concepto de responsabilidad.

\section{I Responsabilidad civil}

El campo actual de los negocios exige que las condiciones en las que se desarrollan cada una de las transacciones u operaciones comerciales, se realicen dentro de un nivel de responsabilidad alto, frente a los posibles incumplimientos, fraudes o simplemente las consecuencias que puede ocasionar la realización de un determinado acto o negocio. Desde una óptica más profunda, esta necesidad de cuidado se ha trasladado no solo al campo contractual, sino también al desarrollo cotidiano de las actividades humanas que pueden ocasionar un daño o perjuicio a otro.

La responsabilidad civil se aprecia desde los fundamentos esenciales del Derecho Romano como vivir honestamente, no dañar al otro, dar a cada uno lo suyo; originándose en estos principios el concepto más profundo de responsabilidad civil que se ha diferenciado ampliamente del daño que puede infringirse uno mismo o del daño moral, temas que seguramente abarcan otros estudios y otras materias. Aquí nos referimos de manera concreta al daño o perjuicio causado a otro, debido al ejercicio de la actividad jurídico civil de las personas con el fin de generar la solución más eficiente para quien sufre detrimento en el curso normal de sus negocios civiles, lo que significa el campo de la responsabilidad civil.

La responsabilidad civil abarca varios aspectos, entre ellos aspectos filosóficos y económicos analizados frecuentemente desde el punto de vista de la justicia. La responsabilidad no se ocupa de lo que está por fuera de la relación bilateral. La responsabilidad civil radica en la obligación que recae sobre una persona que ha infringido daño o perjuicio patrimonial a otra y generalmente su resarcimiento se da mediante un pago de indemnización de perjuicios. 
Esta responsabilidad se funda en el máximo postulado del derecho, cual es el de no perjudicar a otro injustamente (neminemlaedere) y que se traduce en el deber que pesa sobre toda persona, por el hecho de vivir en sociedad, de observar una conducta prudente y cuidadosa para que en el ejercicio de sus numerosas actividades y de sus derechos, no lesione injustamente a otro, deber que incluye el leal y diligente cumplimiento de las obligaciones concretas, voluntariamente contraídas o impuestas por la ley. La violación de este deber compromete la responsabilidad de agente y le acarrea, en consecuencia, la obligación de indemnizar los daños causados. Se tiene, por tanto, que el fundamento en que se apoya toda la institución de la responsabilidad civil es uno mismo, bien sea que se trate de sancionar el hecho ilícito que se ofrece cuando una persona dolosamente o por negligencia perjudica el derecho ajeno, sin estar particularmente obligada a satisfacerlo, o bien, cuando estándolo, no ejecuta la prestación a su cargo destinada a la satisfacción de tal derecho. (Ospina, 1998, p. 32)

Un Estado de Derecho, se define tanto por el principio de legalidad como por el principio de responsabilidad. Se debe recordar que el axioma fundamental de la responsabilidad reside en que el ser humano es libre de sus actos pero esclavo de sus consecuencias, y que frente a la producción de daños no se puede aceptar la impunidad porque ella llevaría al relajamiento de la disciplina y la convivencia sociales. Sería enseñar socialmente que la víctima debe soportar, sin más, los daños injustificados, y que por tanto el responsable está exento de indemnizarla. Con mayor razón se ha de predicar del Estado, que, en síntesis, representa en un territorio determinado la filosofía que debe ilustrar a sus asociados.

La responsabilidad encuentra su fundamento en las consecuencias jurídicas que un hecho acarrea para su autor, esta implica entonces, la necesidad de indagar la causa o razón de ser, de la cual el que infiere un daño a otro está 
obligado a repararlo. La responsabilidad encuentra su fuente en los actos o declaraciones del hombre o en sus hechos y para que estos produzcan efectos se les da la calificación de jurídicos. Al ubicar esta responsabilidad dentro de las fuentes de las obligaciones, se encuentra que esta tiene su fundamente en los hechos jurídicos; de los hechos jurídicos ilícitos, hacen parte los delitos y los cuasidelitos. El legislador ha definido los delitos como los hechos capaces de inferir injuria o daño a otra persona; en otras palabras, es el hecho que encierra dolo. El cuasidelito o culpa, de igual manera, encierra un hecho ilícito, pero cometido por el simple descuido o negligencia.

Para que un hecho genere responsabilidad, es necesario que dicha acción cause un daño a otra persona o a sus bienes, pues no basta su ejecución con dolo o culpa, sin un daño causado qué reparar. Un hecho doloso o culposo que no ocasione un daño qué reparar, posiblemente podrá engendrar responsabilidad penal pero de ninguna manera habrá responsabilidad civil. La víctima tiene a su cargo la demostración plena de los elementos necesarios para generar en la conciencia del juzgador la convicción de que es procedente la condena. Esos elementos son el daño, la culpa y la relación o nexo causal entre los dos primeros.

Es decir que para que una persona se encuentre obligada a resarcir los perjuicios que se derivan de un hecho delictual o cuasidelictual, deben concurrir los siguientes elementos:

- Hecho: la existencia de un hecho que produzca la modificación o transformación de una situación anterior.

- Culpa: elemento de factor subjetivo que determina la relación entre el hecho y la voluntad; como ya lo mencionaremos más adelante, la culpa se refiere tanto al hecho doloso como al culposo.

- Nexo causal: es indispensable que el demandante establezca la relación causa - efecto entre el hecho de la persona, cosa, etc., y el daño que debe ser reparado

- Daño o menoscabo: Es la lesión de un bien o de un patrimonio en su aspecto económico, pecuniario o material como consecuencia directa de un hecho atribuible al autor. (Moreno, 2007, p. 57) 
Lo anterior quiere decir que una vez se haya probado el hecho, la culpa, el nexo causal y el daño o menoscabo, el causante, en este caso el productor o vendedor, debería ser sujeto de responsabilidad por parte del sistema judicial, pues lo contrario equivaldría a exceptuarlo del sistema de responsabilidad que cobija a todos los ciudadanos y otorgarle por lo tanto un privilegio.

La responsabilidad civil puede ser contractual o extracontractual (Tamayo, 2009) tal como se describe a continuación.

\subsection{Responsabilidad contractual}

El incumplimiento de una obligación nacida de un contrato se denomina responsabilidad contractual; a su vez, la responsabilidad civil contractual supone la transgresión de un deber de conducta impuesto en un contrato, es decir, no se trata solo del incumplimiento de la obligación, sino que implica una transgresión. El antiguo derecho romano, no reconocía el vocablo obligación, pero se fundaba en el término "nexum" cuyo significado es ligar, anudar. Este vínculo tenía una representación material ya que el deudor que no pagaba podía ser encarcelado por el acreedor para hacerle responder por su deuda con su propio cuerpo. En la época clásica no era considerada la culpa subjetiva del deudor sino la causa objetiva del incumplimiento, pero ulteriormente con el enfoque Justinianeo apareció la conducta subjetiva del deudor refiriéndola a lo objetivo del incumplimiento. (Hinestrosa, 1986)

Para que pueda discutirse la responsabilidad contractual, es imperiosa la previa existencia del contrato válido, que haya sido perfeccionado por el consentimiento de las partes, revistiendo la forma que la ley señala para cada caso, y que por lo anterior obliga no solo al cumplimiento de lo pactado, sino también a todas las consecuencias de su naturaleza, sea este unilateral, bilateral, oneroso, conmutativo, consensual, instantáneo o de tracto sucesivo, encontrándose en la falta a su puntual cumplimiento - salvo las excepciones consignadas en la ley - por las personas que los otorgan y sus causahabientes, 
la causa de su rescisión y/o la correspondiente responsabilidad del pago de daños y perjuicios, si los hubiere. (Hinestrosa, 1986)

\subsection{Responsabilidad extracontractual}

La responsabilidad civil extracontractual aparece cuando el daño causado no es originado en una relación contractual, sino en cualquier otra actividad. Esta responsabilidad conocida también como responsabilidad Aquiliana, resulta al causar daño a otra persona traspasando el deber de cuidado que se debe tener frente a ciertas situaciones o actividades que pueden generar riesgos y posteriores daños a terceros.(Alessandri, 1981)

La responsabilidad extracontractual, se puede definir como aquella que existe cuando una persona causa, ya por sí misma, ya por medio de otra de la que responde, ya por una cosa de su propiedad o de que se sirve, un daño a otra persona, respecto de la cual no estaba ligada por un vínculo obligatorio anterior relacionado con el daño producido. Esta área del Derecho Civil también se conoce como delitos y cuasidelitos civiles (fuentes de las obligaciones). Las fuentes principales de las obligaciones extracontractuales son el hecho ilícito y la gestión de negocios. (Velásquez, 2004)

Como se observa, en la relación entre el productor o vendedor y el consumidor predomina la responsabilidad civil contractual.

\subsection{Antecedentes Normativos de la Ley I480}

Entrando específicamente en los antecedentes de la Ley 1480 debe mencionarse que la Ley 73 de 1981 estuvo encaminada a crear mecanismos, procedimientos, organismos y regulaciones a través de las cuales el gobierno contó con facultades para intervenir en el control de la distribución de bienes y servicios; estas facultades se relacionaron especialmente con el estableci- 
miento de la responsabilidad de los productores por la idoneidad y la calidad de los productos y servicios ofrecidos, así como por las leyendas, marcas y la publicidad empleadas para su comercialización. Esta ley también incluyó facultades para crear organismos de carácter administrativo y jurisdiccional, así como para expedir normas de carácter sustantivo y de procedimiento, orientadas a garantizarle al consumidor la satisfacción de unas condiciones mínimas de los bienes, la obligación de fijar precios y la regulación para la organización, reconocimiento y operación del régimen de control y vigilancia de las asociaciones y ligas de consumidores. (Acero, et al., 2012)

En 1982 el Decreto 1441 reglamentó la Ley 73 de 1981 en lo relacionado con la creación y el reconocimiento de las ligas y asociaciones de consumidores, para garantizar la protección, información, educación, representación y respeto de los derechos de los consumidores de bienes y servicios, así mismo velar por el pago de las indemnizaciones. Una liga de consumidores fue definida como:

(...) toda organización constituida mediante la asociación de personas naturales, con sujeción a las normas previstas en el presente decreto, cuyo objeto sea garantizar la protección, la información, la educación, la representación y el respeto de los derechos de los consumidores de bienes y servicios, así como velar por el pago de las indemnizaciones a que se hagan acreedores, según la ley, por la violación de sus derechos. (Decreto 1441, 1982, p. Artículo 1).

También en 1982 fue expedido el decreto 3466 en el que se definieron los términos productor, proveedor o expendedor y consumidor, propaganda comercial, idoneidad, calidad y registro de bienes y servicios. A través de ese decreto también se delimitaron aspectos como garantía mínima presunta, marcas, leyendas, propagandas, obligaciones, sistemas de fijación de precios máximos al público, responsabilidad, indemnización de perjuicios y causales de exoneración para productores por idoneidad de bienes y servicios. (Decreto 3466, 1982) 
Fue en 1998 a través de la Ley 446 que el Congreso de la República le otorgó competencias jurisdiccionales a la Superintendencia de Industria y Comercio en asuntos de competencia desleal. Adicionalmente esta ley buscó regular el control de calidad de bienes y servicios ofrecidos y prestados a la comunidad, así lo relacionado con el deber de suministrar información al público durante la comercialización. También esta ley señaló un tipo de responsabilidad civil objetiva o riesgo creado; de acuerdo con Díez (1999), la responsabilidad objetiva se basa en la objetiva inobservancia de normas de cautela, antes que en una valoración del actuar de la persona y de sus perfiles subjetivos; es decir que esta responsabilidad se funda en un deber de comportamiento que espera de un agente en virtud de la actividad que desempeña o de la posición que asume, en lugar de basarse en criterios subjetivos como la culpa. Hierro (2001) afirma que esta responsabilidad prescinde del requisito de la infracción como punto de partida y, como consecuencia de lo anterior, no recurre a la culpabilidad como criterio de imputación objetiva.

De acuerdo con esta teoría, se admite que quien crea un riesgo incurre en la culpa de manera automática. Alessandri (1981) es bastante específico sobre este tipo de responsabilidad cuando afirma que:

La responsabilidad objetiva prescinde en absoluto de la conducta del sujeto, de su culpabilidad; en ella se atiende única y exclusivamente al daño producido. Basta este para que su autor sea responsable, cualquiera que haya sido su conducta, haya habido o no culpa o dolo de su parte. Es el hecho perjudicial, el hecho liso y llano y no el hecho culpable o doloso el que genera la responsabilidad. (p. 10)

Anaya (2012) expone que con este razonamiento no se prescinde de manera absoluta de la culpa para imputar una responsabilidad al causante del daño; de hecho, la culpa siempre está presente, indiferentemente de que se trate de responsabilidad objetiva o subjetiva. Sin embargo, cuando se hable de responsabilidad objetiva la víctima no estará ante la obligación de demostrar que la 
actuación implicó culpa, sino que se trató de una conducta cuyo agente tiene obligación de reparar, por haber causado un daño en el ejercicio de un actividad que le genera beneficio, por lo que se constituye en un riesgo creado.

La responsabilidad objetiva en actividades peligrosas, como es el caso de la prestación de servicios financieros, crea entonces un riesgo, y como tal, es parte del riesgo empresarial en que incurre quien decide ofrecer dichos servicios. Esto implica que las entidades financieras deben ser aptas para tomar las medidas necesarias para controlar o prevenir la producción de un daño, si se tiene en cuenta que, de acuerdo con la Corte Suprema de Justicia: "responde del daño aquel que se encuentra en la posición más adecuada para conducir el análisis costos-beneficios, esto es, a asegurar la conveniencia de evitar el daño comparando los costos relativos y el costo en el cual consiste el daño mismo”.(Sentencia del 24 de agosto, 2009).

Aunque se presentaron varios proyectos de Ley desde 1982, los que no fueron aprobados por el Congreso de la República, fue en 2010 cuando se presentó el proyecto número 089 que se convertiría posteriormente en la Ley 1480 de 2011 en busca de regular las relaciones entre productores, distribuidores y consumidores.

\section{Las Contextualizaciones constitucionales del Decreto 3466 de 1982 y el Estatuto del Consumidor}

Las dimensiones constitucionales y los paradigmas de interpretación de los dos Estatutos del consumidor, objetos de examen de la presente investigación, son totalmente diferentes. El contenido de cada uno de los cuerpos normativos en cuanto sus fundamentos de aplicación son excluyentes, esto se debe a la implementación funcionalista de la constitución de 1991 que fundamenta toda disposición por medio de principios fundacionales.

Por consiguiente, es necesario el examen contextual de los dos cuerpos normativos con el fin de demostrar sus diferencias sustanciales y el avance jurídico respecto a la protección del consumidor. 


\section{I Contexto Constitucional del Decreto 3466 de 1982}

El constitucionalismo contemporáneo tiene como base fundamental la protección de los derechos fundamentales, aquellos que se desprenden de unos principios constitucionales preestablecidos, imperativos categóricos orientados a preservar la máxima de la dignidad humana. La Constitución de Colombia de 1886 tenía carencia de principios constitucionales, por lo que las disposiciones legales eran resultado de organización sistemática sobre un tema regular sin estar inspiradas por normas orientadoras e imperantes para cada caso en concreto.

El Estado Derecho estático que promulgaba la antigua ordenación constitucional afectaba directamente en resolución de escenarios jurídicos en conflicto, porque no se tenía presente los principios establecidos como criterio de interpretación; sino establecía un mero marco conceptual, que a la luz no permitía el garantismo de cada uno de los derechos al limitar el poder decisorio de los jueces. El criterio hermenéutico silogista era propio de la aplicación del anterior estatuto al consumidor, por lo que no existía en caso de litigio una inspiración constitucional, produciendo así una exclusión con el derecho de los jueces.

Por el contrario, la Constitución de 1991 cambia el paradigma constitucional; las Leyes posteriores a su pronunciamiento se inspiran en unos principios rectores que ayudan a despejar cualquier duda en cualquier caso en concreto, lo que promueve que su interpretación funcionalista siempre esté a la mano del juzgador, permitiendo mayor protección a los consumidores.

\subsection{La Constitucionalización del Derecho del Consumidor, Ley I 480 de 20 I I}

La Constitución Política como norma de normas, según lo expresa su artículo $4^{\circ}$, es la base de la construcción normativa en el país; en concordancia 
es claro que bajo esa jerarquía se erigen los fundamentos de las demás normas; en cuanto al Derecho de consumo en la sucesión de las normas que reglamentaban esa materia se encuentra el actual Estatuto del Consumidor Ley 1480 de 2011 el cual se erige como una ampliación de lo estipulado en el artículo 78 siguiendo un lineamiento de protección de los derechos de consumo.

Aunque antes de la Constitución de 1991, la protección y regulación de los derechos de consumo era existente, siempre había falencias en dichas normas, lo que supone que el ámbito de aplicación, protección y alcance de las mismas no era completo; el Derecho como disciplina no puede quedarse estancado en el tiempo, es por esto que la producción normativa siempre se evidencia como forma de responder a los desafíos que surgen en la sociedad y que contradicen los principios establecidos por el Estado para su funcionamiento.

La norma vigente que regula las relaciones de consumo es el "Estatuto del Consumidor” Ley 1480 de 2011, basada en los preceptos constitucionales y desarrollada como mecanismo de protección de los derechos de consumo; al ser posterior al decreto 3466 de 1982 y remplazándolo se entiende que en su contenido es más completo y dispuso cambios significativos por cuanto tiene un amplio alcance en respuesta al crecimiento de las formas comerciales del consumo; para determinar esto primero se debe realizar un análisis comparativo entre normas, es decir entre la Ley 1480 de 2011 y la norma anterior el Decreto 3466 de 1982.

\subsection{Diferencias Conceptuales: Decreto 3466 de I 982 y Ley I 480 de 20 I I}

Para empezar es claro que la Ley 1480 de 2011 en relación a la materia en que se basa en su artículo primero, hace mención de los principios por los que se instituye como norma de carácter protector; dichos principios enfocados en 
el respeto por la dignidad del consumidor se han dividido en cinco numerales; caso contrario al decreto 3466 de 1982 el cual solo se centraba en la regulación de la materia olvidando el espíritu que una norma como mecanismo de protección debe tener.

En relación a los artículos que versan sobre materias similares se encuentra la disposición en ambas normas, en referencia a las características básicas que deben tener los productos para un aprovechamiento adecuado de los mismos; en el decreto 3466 de 1982 se hace mención a la "Calidad" e "Idoneidad” de los productos, el primero en relación a las características inherentes al producto que lo determina como tal, mientras tanto el segundo en la capacidad que posee dicho producto para satisfacer la necesidad para la cua ha sido producido (art $1^{\circ}$, literales E,F). La Ley 1480 de 2011 incluyo otro aspecto: la seguridad" que implica que el producto en su uso no presente riesgos para la salud de la persona que lo utilice; aquí se observa un avance en relación con la protección del consumidor no solo en caso de daño patrimonial sino en salvaguarda de su integridad física, con base en los principios establecidos en la ley.

Las definiciones conceptuales que se hacen en relación a la Ley 1480 de 2011 son una ampliación de las que contemplaba el anterior Decreto 3466 de 1982. En concordancia se observa una inclusión de criterios importantes trayendo consigo un aumento de las formas de comercio y otras implícitas en dicha actividad.

En relación a la garantía se encuentran dos criterios interesantes: el primero desarrollado por el Decreto 3466 como la garantía mínima presunta, entendida para todas las formas contractuales de compraventa; dicha garantía a cargo del proveedor era la forma por la cual aseguraba las condiciones de calidad e idoneidad; el termino de vigencia de dicha garantía se entendía estipulado en el registro de calidad e idoneidad de los productos o en las normas adyacentes o por parte del proveedor. Por el contrario, la Ley 1480, hizo mención a la garantía legal y garantías suplementarias, para determinar de forma 
más justa la forma de reparación cuando el producto no cumple con las condiciones estipuladas; al igual, establece los términos por los cuales se entiende la vigencia de la garantía, así como la libertad de estipulación del término, por parte del proveedor o vendedor, considerando la naturaleza del producto o servicio al momento de perfeccionar el negocio.

En el capítulo II de la Ley 1480 de 2011 se habla dela "Prestación de servicios que suponen la entrega de un bien”. Este aparte en relación al decreto 3466 de 1982 es prácticamente similar al estipular que a dicha actividad también atañe una responsabilidad en la adecuada custodia y manejo del producto y las acciones complementarias para la entrega de dicho producto.

En las formas contractuales está presente la responsabilidad como fundamento para dar cumplimiento a las obligaciones contraídas; ambas normas lo mencionan de forma distinta pero siguiendo el mismo lineamento de imponer sanciones en caso de un incumplimiento de la responsabilidad contraída por los productos comerciados; en la Ley 1480 de 2011 en su Título IV se habla sobre "responsabilidad por producto defectuoso" definiéndolo como un evento en que el producto no es adecuado y causa un daño o riesgo a la salud, la vida o la seguridad de las personas. Aunque este aparte parece novedoso, la otra norma, el Decreto 3466 de 1982 también hacía una distinción similar en sus artículos 23 al 28 respecto de la "Responsabilidad por la calidad e idoneidad de los productos”. En cierto modo ambos contemplan lo mismo pero de forma distinta ya que si el producto no es de calidad y no es idóneo para satisfacer la necesidad, se entiende que no es apto, por consiguiente es un producto defectuoso; a pesar de esto solo se mantenía la visión del daño patrimonial obviando los riesgos a la salud e integridad del consumidor. También en materia de exoneración de responsabilidad se mantienen algunos elementos, como el caso fortuito y la fuerza mayor, los cuales la doctrina ha reconocido en todas las áreas del Derecho.

En el tema de la información es claro que el Decreto 3466 de 1982 solo enfatiza en la publicidad hecha a los productos como en el caso de las 
marcas y las leyendas que contiene las propagandas; aunque está bien definido solo hacía mención a que dicha información fuera adecuada para no inducir en error al consumidor y no había distinción alguna en la responsabilidad de los vendedores y productores de suministrar la información sobre el uso de los productos para un adecuado uso y desempeño; en contraste la Ley 1480 de 2011 amplió este punto y lo dividió en dos títulos el V y VI, respectivamente, como “De La Información” y "La Publicidad” . Sobre el título quinto se puede asegurar que fue un avance significativo por cuanto es una forma en la que se brinda protección al consumidor sobre los bienes o servicios que este adquiere, como en el caso de los productos perecederos y las condiciones especiales contenidas en reglamentos técnicos para el corecto uso o consumo, conservación e instalación del producto o utilización del servicio.

El Título VI, artículo 30 establece la responsabilidad solidaria del anunciante en cuanto a publicidad engañosa cuando obre con dolo o culpa grave al momento de publicar información que no corresponde a la realidad, usando un medio de comunicación.

En cuanto a publicidad de productos nocivos para la salud se debe advertir al público acerca de su perjuicio, uso adecuado y contraindicaciones del caso. Pero en el Decreto 3466 de 1982 esto no se encuentra estipulado, poniendo en riesgo el bienestar de los consumidores. Tanto en el Decreto 3466, como en la Ley 1480, se establecen las mismas pautas para las causales de exoneración de responsabilidad: Cuando el productor demuestre fuerza mayor o caso fortuito, o que la publicidad haya sido adulterada sin culpa alguna del anunciante. En ambas reglas lo referido a promociones y ofertas versa de la misma manera en cuanto a la forma de comunicarle al consumidor sobre términos y condiciones.

En cuanto a protección contractual la Ley 1480 prohíbe la contratación o adquisición de bienes diferentes a los pretendidos por el consumidor para adquirir, el que en realidad quiere, y prohíbe atar contractualmente a los consumidores 
para adquirir o disfrutar los incentivos ofrecidos por el proveedor, es decir las ventas atadas, las cuales no estaban reguladas por el Decreto 3466 de 1982.

En la Ley 1480 se destaca la inclusión de un artículo que pretende proteger al consumidor de posibles cláusulas que a la vista de la ley son prohibidas, puesto que no es permitido modificar unilateralmente el contrato en beneficio de una de las partes, ni tampoco que el productor o el proveedor hagan caso omiso de sus obligaciones en un contrato de adhesión.

Únicamente en el nuevo estatuto del consumidor se encuentra consignada la regulación acerca de la cláusula de permanencia, la cual tiene una duración mínima de un año y máximo dos años solamente para la financiación de bienes y servicios suministrados al consumidor.

La Ley 1480 da un concepto claro acerca de cláusulas abusivas y su prohibición para proteger al consumidor, y advierte a los productores y proveedores que en caso de usarlas estas serán ineficaces de pleno derecho, lo cual es un aporte muy importante, pues el Decreto 3466 de 1982 no cobijaba este tema. El consumidor veía sus derechos contractuales en desventaja frente a los derechos de los productores y proveedores.

El estatuto también regula las operaciones mediante sistemas de financiación, gracias a unas estipulaciones especiales que exigen que se le debe informar al consumidor el monto a financiar y el interés moratorio según la tasa efectiva anual; también se le deberá informar sobre cobro de estudios de crédito, seguros, garantías o cualquier concepto adicional al precio, lo cual el anterior decreto no contemplaba.

En el capítulo quinto de la Ley 1488 de 2011 se encuentran reguladas las ventas que utilizan métodos no tradicionales o a distancia y reglamenta unos deberes especiales del productor y proveedor cuando estos realicen dichos negocios. También da la posibilidad de retractarse dentro de los 5 días siguientes a la iniciación de la relación de consumo o celebración del contrato, con el deber de devolver el bien por parte del consumidor, mientras que el 
proveedor reintegrará el dinero en máximo 30 días a partir del momento en el que se ejerció el derecho, sin hacer descuento o retención alguna.

También hay algunas excepciones al derecho de retracto como: En contrato de prestación de servicios, contratos de suministro de bienes, contrato de servicio de apuestas y loterías, contratos de adquisición de bienes perecederos y contratos de adquisición de bienes de consumo personal. Cuando se den contratos especiales celebrados telefónicamente o por medios electrónicos el productor o proveedor deberá dejar prueba de la aceptación del consumidor a las condiciones generales. Estos temas de ventas a distancia no aparecen regulados en el Decreto 3466 de 1982, se refleja aquí un avance en materia contractual y una actualización normativa conforme a las nuevas tecnologías.

La Ley 1480 reglamenta de manera detallada la protección al consumidor de comercio electrónico y da un concepto del término "comercio electrónico”, el cual es corregido posteriormente por el Decreto 2184 de 2012, así: "Se entenderá por comercio electrónico la realización de actos, negocios u operaciones mercantiles concertados a través del intercambio de mensajes de datos telemáticamente cursados entre proveedores y los consumidores para la comercialización de productos y servicios". (Ministerio de Comercio Industria y Turismo, 2012)

Además de esto se mencionan varios deberes que deberá cumplir el proveedor o fabricante de productos adquiridos por medio de comercio electrónico e indica la posibilidad de imponer sanciones hasta 50 salarios mínimos mensuales legales vigentes. Los proveedores deben tener un enlace dirigido al sitio web de la autoridad que protege a los consumidores en la página donde comercialicen sus productos; además contar con la posibilidad de que los compradores o consumidores puedan poner sus quejas o reclamos, verificar la edad del consumidor y autorización de los padres, en caso que el comprador sea menor de edad. Además debe tener como mínimo el nombre o razón social, documento de identificación o NIT, un método de contacto como la dirección física de notificaciones y los teléfonos. 


\subsection{Las Facultades de la Superintendencia de Industria y Comercio.}

La Superintendencia de industria y comercio podrá imponer medida cautelar de bloqueo de acceso a la página o sitio web hasta por 60 días mientras se hace la investigación administrativa. Estos avances son bastante útiles para controlar los negocios comerciales hechos por medio de las nuevas tecnologías para proteger los derechos del consumidor.

El nuevo estatuto aclara los siguientes conceptos, que no incluía el antiguo decreto:

- Especulación: es la venta de bienes o la prestación de servicios a precios superiores a los fijados por la autoridad competente.

- Acaparamiento: es la retención de bienes para desabastecer el mercado con el fin de lograr su alza en materia de precios.

- Usura: es recibir o cobrar a cambio de préstamo de dinero o venta de bien, intereses por encima del interés corriente bancario más elevado. (Colombia, Congreso de la República, 2011)

Es preciso indicar que tanto en el Decreto 3466 de 1982 como en la Ley 1480 de 2011, se establecen disposiciones concernientes a velar por la protección del consumidor, con parámetros establecidos, los cuales contribuyen al desarrollo eficaz de la relación comprador y vendedor y su forma de regulación.

La Ley 1480 de 2011, como norma protectora regula y establece pautas para la aplicación de las formas de protección, como en el caso de los productos defectuosos, al imponer una sanción apoyándose en los mecanismos creados por el derecho civil y comercial tendiente al cumplimiento de las garantías, según lo estipulado por la ley.

Respecto de la acción de protección al consumidor se establecen los parámetros del campo de aplicación de la Superintendencia Financiera y cómo 
esta vela por la protección del consumidor, y su posición, frente a cualquier caso, como juez para decidir, única y exclusivamente en lo que se enmarca dentro de sus facultades; el proceso que se maneja a partir de esta disposición se encarga de llevar a cabo los procedimientos sobre la violación a los derechos de los consumidores, indicando facultades para la Superintendencia de Industria y Comercio como ente superior que regula la relación, respecto de las garantías y la manera cómo actúan las demandas por efectividad en la garantía de los productos, las cuales deberán presentarse dentro del año siguiente a la expiración de la misma; así mismo las controversias que surjan del contrato dentro del año siguiente a su terminación contrato En cualquiera de los casos mencionados, el consumidor deberá aportar prueba de la reclamación que se efectuó durante la vigencia de la garantía.

De acuerdo con lo que se indica en la nueva Ley 1480, para llevar a cabo una acción judicial frente a la garantía, esta deberá venir acompañada con la identificación del producto que se adquirió, fecha en la que se adquirió o se prestó el respectivo servicio y las pruebas que indican los defectos del mismo. La reclamación por parte del consumidor podrá ser escrita o verbal En el primer caso, se puede hacer mediante medios electrónicos. Si se realiza por medio telefónico, en la llamada se deberá garantizar quién está encargado de recibir dichas reclamaciones; que la misma quede grabada de manera verbal; y se deberá expedir constancia de quién recibe la reclamación. Si se envía por correo se deberá aportar la constancia de envío a la dirección donde se adquirió el producto o se recibió el servicio. La respuesta por parte del productor o vendedor que prestó el servicio deberá entregarse dentro de los 15 días hábiles siguientes con todas las pruebas a que haya lugar. Si este se negó a expedir constancia o reclamación se deberá afirmar bajo juramento por parte del consumidor lo que se indicó.

Las partes en su accionar con el fin de obtener un resultado satisfactorio podrán practicar pruebas ante los peritos que se designen por parte de la Superintendencia de Industria y Comercio y en este caso la misma someterá a un estudio las pruebas obtenidas. Pretensiones, hechos y pruebas de- 
limitan el actuar de la Superintendencia. Las partes únicamente podrán pedir práctica de pruebas que no le haya sido posible practicar en la reclamación ante el proveedor, esto porque si no reciben una respuesta satisfactoria, el consumidor tiene el derecho de acudir ante el juez competente. Todo lo anteriormente descrito se encuentra dentro de la nueva normativa que regula el derecho del consumidor y enumera el paso a paso de la protección que se le da y las acciones legales que puede emprender para que sea resuelto su problema.

En la regulación que se da en el nuevo Estatuto del Consumidor se establecen las facultades que se le otorgan administrativamente a la Superintendencia de Industria y Comercio; es de gran relevancia el aparte en el cual se indica que debe ser esta quien instruya a los destinatarios de la norma para que la conozcan y la apliquen de la manera debida sin sobrepasar los derechos de los demás, y la práctica de inspección a los lugares donde se ejecutan actividades encaminadas al comercio. para verificar si se cumple o no con las disposiciones que se consagran en el Estatuto del Consumidor.

Así mismo se la faculta para fijar el término de la garantía legal para los bienes y servicios que se prestan cuando se considere necesario, así como los requisitos mínimos de idoneidad y calidad para determinados bienes, mientras se emite el respectivo ordenamiento que determine su debida distribución y control. Las sanciones administrativas se harán de conformidad a lo contencioso administrativo. En su interior el Estatuto faculta a la Superintendencia de Industria y Comercio para la imposición de sanciones sobre el control de precios, que pueden variar dependiendo del grado de la falta cometida: entre 300 y 2000 salarios mínimos,, cuando no se acatan las normas establecidas en el Estatuto. En el caso de graduación de la multa se pueden tomar los daños que se han causado, cuando se persiste en el error cometido, la reincidencia en el mismo, etc. De lo anterior se consigue un resultado satisfactorio debido a que lo obtenido por medio de las multas contribuye al sostenimiento o fortalecimiento de la red nacional de protección al consumidor. 
La Superintendencia, en los lugares donde no se encuentra ubicada, podrá ser suplida por alcaldías, intendencias delegadas departamentales, consultorios jurídicos, etc., que deben brindar atención e información al público sobre las funciones que se asignan y entregar el material indicado para la respectiva información a los consumidores. Así mismo el superintendente estará facultado para delegar facultades a aquellos integrantes del sistema de protección en la respectiva jurisdicción a la que pertenecen, tales funciones son las de recibir denuncias, solicitudes, respuestas, suministrar la respectiva información sobre el estado de trámites y solicitudes, y notificar actuaciones de la Superintendencia, para archivar expedientes; la entidad podrá hacerlo en los casos de cobro coactivo correspondientes a recaudaciones relacionadas por sanciones impuestas por violaciones al estatuto del consumidor, cuya cuantía no exceda los 50 salarios mínimos, siempre que tengan 5 años de vencidas.

\section{El Concepto de Calidad en el Estatuto del Consumidor- Ley I 480 de 20 I I}

Respecto de la calidad en el estatuto del consumidor se tienen unidades legales de medida que se enmarcan dentro del artículo 68 de la presente ley; así mismo se manejan unidades acostumbradas de medida que incluyen unidades específicas para que se apliquen particularmente, dependiendo de las necesidades del comercio internacional, para usos específicos tales como la navegación marítima, por razones de investigación científica o por razones de seguridad (Ley 1480 de 2011 art 69).

Las tasas en materia de metrología, que es aquella ciencia que estudia los sistemas de pesas y medidas, en este caso queda en cabeza de la Superintendencia de Industria y Comercio. La respectiva entidad debe fijar las tasas para servicios de metrología que se presten. Las tasas que se establezcan buscaran la recuperación total o parcial de costos enmarcados en la prestación del servicio. 
Por otra parte los reglamentos se deberán expedir de conformidad a lo contemplado por la OMC (Organización Mundial de Comercio, art. 72, Ley 1480 de 2011).. La red nacional de protección al consumidor se conformará por consejos de protección al consumidor de carácter local o nacional, como por ejemplo ligas y asociaciones de consumidores. quienes podrán celebrar convenios con entidades de orden nacional, departamental, etc., para todo aquello que tenga relación con la protección al consumidor en todos los lugares del territorio nacional. Esta red nacional tendrá como función primordial difundir y apoyar el cumplimiento de los derechos de los consumidores.

El ministerio responsable de cada sector administrativo (art 76 Ley 1428 de 2011) deberá garantizar y facilitar los espacios para la discutir y difundir todos los aspectos que se enmarquen dentro de la protección al consumidor. El Gobierno Nacional reglamentará la manera como los servicios de justicia que se establecieron para la protección al consumidor se ejecuten de manera efectiva.

Dentro del presente estatuto se enmarca un aparte del contrato de compraventa a plazos: el consumidor podrá pagar con anticipo parcial o totalmente el precio pendiente sin que en ningún caso le sean exigibles intereses ni sanciones económicas.

En relación al Decreto anterior, es decir el 3466 de 1982, en concordancia con lo anteriormente enunciado, es preciso indicar algunos apartes que se mantienen con e la promulgación de la nueva norma, en aspectos relativos a las garantías que se establecieron, como por ejemplo, el establecimiento de las sanciones administrativas que se enmarcan en la anterior normativa, por el incumplimiento de las condiciones de calidad e idoneidad registradas; ya se indicaba la manera como se amparaba a favor del tesoro público si ocurría un inconveniente frente a la subsanación del pago de las mismas, si se reitera o se reincide. 
De igual manera las sanciones que se contemplan de conformidad al incumplimiento de las condiciones de calidad e idoneidad que no se registran, también se incurre en la implementación de la respectiva multa; de igual manera, se establecen causales de exoneración para las mismas. Con el anterior decreto la imposición de sanciones por la fijación pública de precios, cuando se incumplía lo pactado en el decreto, también recaía en la Superintendencia de Industria y Comercio, tal y como se observa en el estatuto actual.

Se fijaron las funciones de la Superintendencia de Industria y Comercio en lo que atañe a la investigación, aquello que concierne a la garantía mínima presunta para determinados bienes y servicios, ya que el decreto anterior establecía algunas garantías para la protección del consumidor.

Es claro precisar que el anterior decreto estaba formulado de una manera más general y no abarcaba todos los temas de una manera más supeditada y especial; el nuevo estatuto establece las pautas que se deben mantener y llevar a cabo para la debida protección de los derechos del consumidor, en lo que respecta a la garantías establecidas por el anterior, en contraste con el nuevo.

El nuevo Estatuto de protección al consumidor, Ley 1480 de 2011 no aporta grandes cambios frente a las normas legales que se venían aplicando. Tampoco deroga ni remplaza las normas especiales de cada sector económico, ni hace obligaciones de resultado a todas aquellas en las que resulte involucrado un consumidor con un productor o proveedor de cualquier producto o servicio.

La nueva reglamentación de protección al consumidor implantó cambios como una ampliación del ámbito de aplicación de las normas, de manera que ya no se requiera que los productores o proveedores tengan un ánimo de lucro para que las normas les sean aplicables, así que el que se presuma proveedor o distribuidor de un producto, quien impone un signo distintivo sobre el mismo. 
Por lo anterior, la polémica surgida por la expedición del nuevo Estatuto del Consumidor en Colombia, en relación a su extenso campo de aplicación es, en cierta medida, desproporcionada. Siendo pocos los nuevos sectores que entran a estar regidos por estas normas, tampoco introducen grandes cambios en los regímenes de responsabilidad aplicables a los productores y proveedores de cualquier bien y servicio en Colombia. 


\section{Referencias}

Acero, Y., López, C., \& Prieto, M. (2012). Análisis y recomendaciones al estatuto del consumidor Ley 1480 de 2011 en el marco normativo del derecho español. Bogotá: Pontificia Universidad Javeriana. Especialización de Derecho Comercial.

Alessandri, A. (1981). De la responsabilidad extracontractual en el derecho civil. Santiago de Chile: Imprenta Universal.

Anaya, C. (2012). Riesgos en las transacciones electrónicas bancarias. Una carga que debe ser asumida por la Banca. Mercatoria. Mercatoria, volumen 11 (número 1), 287-331.

Congreso de la República. (2011). Ley 1480. Por medio de la cual se expide el Estatuto del Consumidor y se dictan otras disposiciones.. s.l.:Diario Oficial No. 48.220.

Corte Constitucional. (2000). Sentencia C-662. Magistrado Ponente Fabio Morón Díaz. Bogotá: Corte Constitucional.

Corte Constitucional. (2002). Sentencia C-973. Bogotá: s.n.

Decreto 1441 (1982). Por el cual se regula la organización, el reconocimiento $y$ el régimen de control $y$ vigilancia de las ligas y asociaciones de consumidores y se dictan otras disposiciones. Bogotá: Presidencia de la República.

Decreto 3466 (1982). Por el cual se dictan normas relativas a la idoneidad, la calidad, las garantías, las marcas, las leyendas, las propagandas y la fijación pública de precios de bienes y servicios, la responsabilidad de sus productores, expendedores y y se dictan otras disposiciones. Bogotá: Presidencia de la República.

Díez, L. (1999). Derecho de años. Madrid: Civitas.

Hierro, L. (2001). La responsabilidad en el Derecho. investigación sobre el concepto jurídico de responsabilidad. En: F. Pantaleón, ed. Anuario 
de la Facultad de Derecho de la Universidad Autónoma de Madrid. Madrid: Universidad Autónoma de Madrid.

Hinestrosa, F. (1986). Estudios de Derecho Privado: homenaje al Externado en su Centenario. Bogotá: Universidad Externado de Colombia.

Ley 115. (2000). Estatuto de Defensa del Consumidor. Bogotá: Cámara de Representantes.

Ley 82 (2008). Actualización del Decreto 3466 de 1982 y se dictan otras disposiciones. Bogotá: Senado de la República,

Ley 1480 (2011). Por la cual se dictan normas relativas a la idoneidad, la calidad, las garantias, las marcas, las leyendas, las propagandas, la fijación pública de precios de bienes y servicios, y la responsabilidad de sus productores, expendedores y proveedores. Bogotá: Congreso de la República.

Ley 446 (1998). Por la cual se adoptan como legislación permanente algunas normas del Decreto 2651 de 1991, se modifican algunas del Código de Procedimiento Civil, se derogan otras de la Ley 23 de 1991 y del Decreto 2279 de 1989, se modifican y expiden normas del Código. Bogotá: Congreso de la República.

Ministerio de Comercio Industria y Turismo (2012). Decreto 2184. s.l.:MIN. Fernando Carrillo, Bogotá, D.C.: Colombia.

Moreno, J. A. (2007). La responsabilidad civil y su problemática actual. Madrid: Dikinson.

Ospina, G. (1998). Régimen general de las obligaciones. Bogotá: Temis.

Sentencia del 24 de agosto, 2009. Sentencia del 24 de agosto de 2009. Bogotá:

Corte Suprema de Justicia..

Tamayo, A. (2009). La Responsabilidad Civil Extracontractual y la Contractual. Bogotá: Doctrina y Ley.

Velásquez, O. (2004). Responsabilidad civil extracontractual. Bogotá: Editorial Temis. 


\title{
III. \\ EL USUARIO DE \\ LOS SISTEMAS PIRAMIDALES: \\ ¿CONSUMIDOR A PROTEGER O [IR] RACIONAL APROVECHADOR DEL ESTADO?*
}

\author{
Javier Francisco Franco Mongua \\ Javier.franco@ugc.edu.co
}

\footnotetext{
*Este capítulo es producto de mis actividades investigativas dentro del proyecto titulado EL DERECHO COMPARADO DE LA PROTECCIÓN AL CONSUMIDOR: LOS CASOS COLOMBIANO Y ARGENTINO, que se adelanta en el Centro de Investigaciones de la Facultad de Derecho de la Universidad La Gran Colombia. (Bogotá). Sobre el mismo tema se presentó una ponencia en el encuentro de la Asociación Latinoamericana e Ibérica de Derecho y Economía (ALACDE) en la ciudad de Santo Domingo, República Dominicana en el año 2015. Sobre el inversionista en empresas multinivel se presentó ponencia en el encuentro de ALACDE 2016 en Santiago de Chile.
} 

Resumen. Este estudio parte de la certeza de que existe un grado de racionalidad en los individuos que participaron en los esquemas piramidales, que generaron la crisis socioeconómica de 2008 en Colombia. Consideramos que la racionalidad intrínseca de los ciudadanos debe ser evaluada al momento de determinar la responsabilidad de los mismos en el desarrollo de las pirámides; y en particular, en las pérdidas sufridas por ellos mismos. Como hipótesis fuerte, sostenemos que es irracional para los ciudadanos creer en los altos rendimientos ofrecidos por estas sociedades, y con base en esto, proponemos que es improcedente la reclamación de Responsabilidad del Estado. Por el contrario un análisis juicioso de la dinámica de las pirámides devela configurada la causal de exoneración tipificada como culpa exclusiva de la víctima.

Palabras clave. Racionalidad, racionalidad limitada, esqumas Ponzi, análisis económico del derecho.

\section{Introducción}

Durante el 2008, en Colombia salieron a la luz pública una serie de escándalos por los hasta entonces desconocidos esquemas Ponzi (pero ya famosos esquemas piramidales), que (Salazar y Franco 2009, 89) explican así:

Una pirámide no es más que un conjunto creciente, pero acotado, de inversionistas conectados por una red que brinda los caminos para que un núcleo inicial de adherentes se expanda a través de la vinculación de amigos, conocidos y familiares quienes, a su vez, vinculan a los suyos en un proceso que se repite hasta alcanzar ciudades enteras, y en ocasiones países completos, como fue el caso de Albania en 1997. Pero la pirámide no es la red social. Al estar incrustada en ella se expande a través de sus caminos, aprovechando las secuelas de vínculos que unen a un individuo con otro en su red social. Su motor económico son los altos intereses ofrecidos 
sobre el capital: más altos que los de cualquier con otra alternativa financiera disponible en el mercado. Su motor social está en la estructura de la red en la que engancha a sus primeros inversionistas y crece hasta ${ }^{1}$ que las expectativas de sus clientes lo permitan. Una pirámide, entonces, en una estructura social temporal incrustada en una red social más amplia, a la que "explota”, en términos de contactos y de información, para crecer. (Salazar y Franco 2009, 89)

En virtud de la intervención estatal a varias sociedades en las que se prometía una irrazonable rentabilidad de los dineros entregados por los ciudadanos1. Más allá, se generaron acusaciones de lavado de activos y captación masiva ilegal de dinero, y como consecuencia de su estrepitosa caída, los sistemas Ponzi dejaron atrás una crisis socioeconómica de dimensión nacional, particularmente fuerte en departamentos como Putumayo, Nariño, Cauca, Valle y el Eje Cafetero. Para noviembre, cuando el fenómeno de las pirámides había permeado a todas las clases sociales, la sociedad DRFE se declaró insolvente, y las denuncias contra la sociedad denominada DMG, hicieron necesario que para el 17 de noviembre el Gobierno Nacional declarara un estado de emergencia social debido a las protestas, pérdidas económicas y surgimiento masivo de estas sociedades.

En este orden -y dado el conocido adagio- para no repetir la historia. es de interés analizar el surgimiento, acogida, desarrollo y caída de los Esquemas Ponzi en nuestro país, para extraer, a suficientes años de distancia, las enseñanzas que dejó la crisis. Este estudio se hace de capital importancia cuando, aún después de la crisis del 2008 y de las advertencias (Superintendencia de

\footnotetext{
1. Siendo las sociedades DRFE y DMG, las más grandes en términos de estructura y afectación, por sus gran acogida en su auge en la red social nacional e internacional. Sin embargo, otras que surgieron fueron: GroupWinner, DMG, Proyecciones DRFE, PeopleWinner, SP Progresar, Inversiones Alina, Universal de Inversiones, Inversiones Bonilla, Trébol Inversiones, EuroAcciones, Mar del Plata, Fundación FPC, Superservi, Inversiones Anglo, Inversiones H y R, Inversiones MGA, FAP, DIO, Superservice, Convenio Motor Ltda, Taxis cab. Ltda., Sintra Ltda, Admicar, El mundo de los regalos y/o inversiones en red, Word Bussines Panamá EU, Travel Tour Inversiones, Fundación Crea y Sueña-Funseca, J\&J Cleans Ltda, Empresa Unipersonal de Desarrollo, Speed Cash Ltda, El Mundo Global del Dinero Ltda., Comercializadora IIP S.A., Inversiones Flor del Llano, Fundación Solidaridad Merco, Inversiones Internacionales Golden Gate S.A., Inversiones Grupo Safengo EU., EvolutionMarket Group, DMB World Bussiness, New Working Ltda, Rapi Red, Century franchise.
} 
Sociedades, 2015) de las Superintendencias de Colombia ${ }^{2}$, aun para este año 2015, se sigue presentando este fenómeno ${ }^{3}$. Es imprescindible evitar que a pesar de las advertencias; de lo visto en el pasado (2008); y de manera irracional, pretendan los afectados alegar la responsabilidad del Estado por su obligación de vigilancia y control de dichas sociedades.

\section{I.I La racionalidad del inversor}

El individuo toma decisiones racionales. Cuando piensa en invertir, estas decisiones buscan maximizar su utilidad y reducir sus costos mediante la elección racional. Así, a quien se le presenta una forma de invertir dinero para obtener de él rendimientos, ordinariamente, decide invertir. Sin embargo, dicha decisión, en cuanto a maximizar la utilidad y reducir costos al invertir, debe ser racional (Kahneman, 1982). Este es el caso inesperado de las denominadas pirámides, que han surgido, en cierto grado, por falta de atención al mencionado postulado, toda vez que no siempre el individuo toma las decisiones más óptimas. Por tanto, se evidencia una limitación en la racionalidad del individuo al tomar decisiones económicas y, además, la toma de algunas decisiones irracionales respecto a la inversión en los Esquemas Ponzi o piramidales.

Cuando observamos el comportamiento de los usuarios frente a las pirámides, nos encontramos frente a un error de juicio que Kahneman describe como “insensibilidad a la predictibilidad” (Kahneman, 1982). Desglosado, este concepto nos da una idea muy clara sobre un aspecto del comportamiento humano que nos ayudará en nuestro análisis. Este autor realiza el siguiente experimento: describe en varios párrafos el desempeño de algunos monitores (estudiante-docente) durante una clase de práctica, y posteriormente pide a un grupo de estudio que califique el desempeño de los monitores según

2. Estas son las encargadas en Colombia de vigilar y controlar las sociedades y entes financieros: la Superintendencia de Sociedades y la Superintendencia Financiera.

3. Referencia: http://www.dinero.com/inversionistas/articulo/piramides-captan-dinero-bajo-otras-modalidades-colombia/187050 
la descripción dada; y a otro grupo, que prediga el éxito de los mismos en los próximos cinco años. El resultado del experimento entrega una bella analogía frente al caso de los usuarios de las pirámides, que en la práctica tuvieron que evaluar el rédito de sus inversiones y al mismo tiempo, basados en la misma información, predecir el comportamiento de las mismas a futuro.

Podemos imaginar la respuesta. Los monitores evaluados positivamente recibieron también predicciones favorables a futuro. Así mismo, los usuarios que recibieron ganancias por sus inversiones, predijeron que las mismas seguirían presentándose.

La insensibilidad a la predictibilidad es la tendencia general de las decisiones intuitivas a ignorar el valor de la información en su capacidad para predecir una probabilidad. El ejemplo de Kahneman es, curiosamente, menos evidente que el nuestro. Cuestiona el autor la posibilidad de predecir el desempeño de un monitor durante cinco años futuros basado en la información de una sola clase. Estamos de acuerdo, y agregamos que el ejemplo de los usuarios de las pirámides se presenta mucho más claro. A saber, es imposible predecir el desempeño de la 'inversión' basado en un primer resultado exitoso.

Otros errores de los juicios que de ordinario se presentan en la vida cotidiana son narrados por el autor. Por ejemplo, señala Kahneman cómo los resultados redundantes de una pequeña muestra son considerados más confiables que resultados diversos de una muestra más grande. Ejemplificándolo con nuestra situación, los usuarios de las pirámides pudieron considerar más confiable el resultado positivo que sus conocidos tuvieron al invertir en estos sistemas por sobre la regla generalizada (pero abstracta) de que los mismos sistemas colapsan inevitablemente (el autor llama a esta tendencia 'insensibilidad al tamaño de la muestra ${ }^{34}$. Íntimamente relacionada a las anteriores es-

\footnotetext{
4. De manera más precisa, considérese el siguiente ejemplo: De una bolsa llena de bolas rojas y blancas se saca una muestra de 5 y otra de 20 . La primera resulta en una proporción de 4:1 en favor del color rojo, y la segunda de 12:8 en favor del mismo color. Ambas relaciones favorecen la idea de que la mayoría de bolas en la bolsa son rojas; pero el lector no tendrá dificultad en reconocer que, aunque la segunda relación sea menor (3:2), el tamaño de la muestra la hace más confiable que la primera.
} 
tá, también, la 'ilusión de validez', también conocida como 'falacia inductiva' que implica que una serie de resultados consistentes generan la ilusión de que es posible realizar predicciones basados en estos resultados. Esta consideración es particularmente relevante, pues observa el autor que 'un resultado elemental en la estadística correlacional muestra que, dados ciertas entradas (datos) de validez establecida, una predicción basada en dichas entradas alcanza mayor precisión cuando las mismas son independientes de cada una, más que cuando las mismas resultan redundantes. Así pues, la redundancia entre estas bases reduce la precisión de nuestras predicciones, aun cuando [paradójicamente] incrementa nuestra confianza en las mismas ${ }^{5}$. Dicho en otras palabras, los usuarios encontraron confiables (de manera irracional) los resultados obtenidos por sus inversiones en las pirámides porque, por un tiempo, estos fueron consistentes. Pero esta posición es absurda, pues para elaborar una predicción a partir de estos resultados (nuestros datos o entradas) convenía buscar variedad (independencia) entre los mismos, y no una constante de aparente éxito. Una última precisión aclara esta idea con un ejemplo: Doce meses de ingresos variables de un trabajador independiente son, a todas luces, una mejor base para predecir sus ingresos en el próximo año, que un salario constante devengado por un empleado por el mismo período de tiempo si no tenemos certeza de que seguirá en el mismo empleo.

Las consideraciones anteriores parecen apoyar la idea de que la elección irracional es la regla y no la excepción, y por consiguiente contradeciría nuestra base, según la cual los 'usuarios' deben considerarse racionales. Podemos decir más en contra de nuestra posición. Desde hace un siglo, consideraba Freud (2000) que la racionalidad se predica de los individuos y no de las masas. Cuando forma parte de un grupo-decía el autor-el individuo pierde su capacidad de decidir racionalmente, y se deja guiar por su necesidad de pertenecer al grupo o, lo que es lo mismo, por 'seguir la corriente'. Bien podríamos pensar que la decisión de invertir en las pirámides fue una conducta ma-

5. Traducción libre: “[...] an elementary result in the statistics of correlation asserts that, given input variables of stated validity, a prediction based on several such inputs can achieve higher accuracy when they are independent of each other than when they are redundant or correlated. Thus, redundancy among inputs decreases accuracy even as it increases confidence $[\ldots]$ ” 
siva, no individual. Los primeros inversores, unos conscientes de que sus resultados serían positivos dado el funcionamiento del sistema piramidal, y otros ingenuos pero afortunados, arrastraron a la comunidad cuando los primeros resultados fueron positivos, y guiados ya por una lógica de masa (valga el oxímoron) los individuos no podían actuar racionalmente.

La psicología de las masas nos entrega algunos datos interesantes frente al comportamiento del individuo dentro de un grupo (Myers, 2010). Robert Zajonc (1965) nos dice que, en el grupo, las respuestas dominantes se ven fortalecidas sin importar su validez. Por su parte, Latané, (1981) sostiene que la influencia del grupo aumenta con el crecimiento del mismo. James Stoner (1968) argumenta que, en un grupo, las personas tienden a tomar decisiones más arriesgadas, e Irvin Janis (1982) demostró que dentro de los grupos las decisiones disidentes, aunque acertadas, son reprimidas. Así, puede considerarse que los usuarios del sistema piramidal, una vez dentro del mismo, ven favorecida la tendencia a invertir a pesar de la irracionalidad y el riesgo de su decisión, mientras que las voces que advierten sobre esta irracionalidad son acalladas.

Consideramos acertadas las posiciones anteriores. Sin embargo, somos incisivos en que, aún halladas excusas para el comportamiento de los 'usuarios' que en cierta manera haga comprensible la irracionalidad de sus acciones, estas derivan en su contra. Pues si hemos de admitir que los usuarios de las pirámides actuaron de manera irracional, surge de inmediato la pregunta de si el Estado debe pagar las consecuencias de estos actos. Es precisamente esta la pregunta que nos formulamos al final de esta ponencia. Podemos, sin embargo, afirmar que de nuestra exposición anterior resulta de entrada una diferenciación entre los clientes de las pirámides. Por una parte, quienes de "buena fe", mal informados o con bajos niveles de educación - en especial de sectores sociales de bajos y medios ingresos- creyeron en las altísimas tasas de retorno a sus inversiones; y de otro lado, los que sabiendo - o sospechando- de las características piramidales de tales inversiones, “calculaban” poder obtener recursos y recuperar su inversión antes que el esquema hiciera crisis. 
El individuo, al buscar maximizar su utilidad y disminuir sus costos, debe tomar decisiones de carácter racional. Cuando este supuesto es ignorado (cuando decide invertir en una pirámide que establece unos altos rendimientos (Salazar Trujillo \& Franco Escobar, 2009) $)^{6}$ ), no puede ser premisa sobre la cual pretenda una declaración e indemnización surgida de la responsabilidad extracontractual del Estado ${ }^{7}$ por la denominada falla del servicio, toda vez que la elección del individuo se encuentra limitada por el marco de la racionalidad. Sin embargo, no se puede ignorar en este punto que, si bien la racionalidad se predica de todos los individuos, no es menos cierto que esta racionalidad se ve afectada no solo por lo expuesto anteriormente, sino por circunstancias particulares, como la falta de educación y la necesidad apremiante por obtener recursos económicos, factores que encontramos regularmente en las clases bajas y medias de la población. Para analizar este punto exponemos un caso que muestra la racionalidad y sus límites en el ámbito económico-jurídico, siendo así su interdisciplinariedad con la normativa jurídica financiera y responsabilidad del Estado frente a las pérdidas económicas de las personas en las pirámides o Esquemas Ponzi, ya que comporta un tema de actualidad ${ }^{8} \mathrm{e}$ importancia por los efectos económicos, jurídicos y sociales -en cuanto a la racionalidad del ciudadano de cualquier clase social ${ }^{9}$ -

\footnotetext{
6. Los altos rendimientos prometidos y las redes sociales configuran la estructura que sustentan el nacimiento y el desarrollo de las denominadas pirámides, pero dentro de estas opera una serie de procesos racionales que pueden restringir, mantener o promover crecimiento, permanencia o decrecimiento.

7. Dentro de las demandas más costosas, en términos monetarios por indemnizaciones, contra el Estado colombiano son aquellas justificadas en la garantía de vigilancia y control que debió tener el Estado y la Superintendencia financiera respecto a las actividades adelantadas por las empresas captadoras masivas de dinero, pirámides. Tomado de: Referencia: http://www.elheraldo.co/local/las-25-demandas-mas-costosas-contra-el-estado-176694, [tomado el 19/03/15, a las 2:49 pm]
}

8. Estos esquemas Ponzi o piramidales se presentaron hacia los años veinte en los E. E. U. U., se presentaron en el año 2008 en Colombia de forma clara y, sin embargo, se siguen presentando.

9. Véase,http://www.elespectador.com/noticias/nacional/piramides-financieras-el-estrato-6-mira-de-autoridades-video-552740 


\section{I.2. El caso Interbolsa}

Existe un paralelo importante entre la situación generada por las pirámides y el caso Interbolsa, ocurrido en Colombia a finales del 2012. En este acápite nos centraremos en dos hechos importantes del caso, el segundo consecuencia del primero. En primer lugar, la sociedad Interbolsa era una entidad vigilada por la superintendencia financiera; y esto (entre otros factores) en segundo lugar, generó una confianza legítima en sus inversores.

El objeto social de Interbolsa, contenido en el artículo 3 de los Estatutos Sociales de Interbolsa SAI era recibir en dinero suscripciones del público con el fin de constituir o administrar carteras colectivas y fondos de capital privado en los términos que regulan la materia ${ }^{10}$. Así, en concordancia con el artículo 75 de la Ley 694 de 2005 y el artículo 11.2.1.6.1 del Decreto 2555 de 2010, se encontraba sometida a la vigilancia de la Superintendencia Financiera.

Si la sociedad ha sido llamada 'pirámide de estrato 6' se debe a un hecho sobre sus actividades y a un equívoco en sus actuares. El hecho es que la sociedad se dedicaba a celebrar contratos de comisión para la compra y venta de acciones, negocio que en Colombia es propio de las personas adineradas. El equívoco es que las maniobras de los responsables de Interbolsa fueron mucho más allá de la captación masiva de dineros, e involucraron especulación y manipulación de precios sobre el mercado de valores. Los hechos detallados del caso no son sencillos, pero en resumen, Interbolsa llegó a invertir más de 300.000 millones de pesos en acciones de la empresa Fabricato, y con base en estas acciones, consiguió fondos del sistema bancario a través de operaciones repo. La razón de esta inversión fueron las excelentes expectativas que se tenían de Fabricato, en particular por las oportunidades que le supondría la entrada en vigencia del TLC con los Estados Unidos y el interés manifestado por parte de una sociedad brasilera en la compra de dicha empresa. Los repos, por su parte, consisten en operaciones de venta de acciones con pacto de re-

10. Superintendencia Financiera de Colombia. Resolución Número 1125 de 2014. 
compra a un precio pactado (Sanchez, 2003). La diferencia entre el precio de venta y de recompra era el interés que perseguían los bancos de los cuales Interbolsa conseguía principalmente sus fondos. En el caso, la comisionista compró las acciones de Fabricato con la confianza de que su desempeño futuro produciría enormes ganancias. Sin embargo, factores externos e internos debilitaron las expectativas sobre el desempeño de Fabricato, pero de alguna forma (aparentemente, mediante maniobras fraudulentas ejecutadas por los accionistas mayoritarios de Interbolsa a través de operaciones ficticias) sus acciones ascendieron de 26 a 90 pesos en un año, y los contratos de repo se seguían celebrando con base en estos precios, lo que a la larga llevó a la empresa a una situación de iliquidez que precipitó su intervención e inmediata liquidación en noviembre de $2012^{11}$

Como se ve por su objeto social, los hechos y las acciones de la Superintendencia Financiera, Interbolsa era una sociedad vigilada formal y efectivamente por dicha entidad; lo que de entrada la diferencia de las empresas que durante el 2008 escondieron esquemas piramidales. Pero esta vigilancia importa a otra consecuencia. Y es que en segundo lugar, dadas las actividades, el contexto y la presentación de Interbolsa, las expectativas de sus clientes-inversionistas se presentaban como racionales.

Las operaciones aparentemente fraudulentas de Interbolsa son de una complejidad cuyo análisis detallado escapa al propósito de este artículo. Nos limitamos, por economía, a evidenciar que su fachada se mostraba legítima a los ojos de un cliente diligente y racional. Baste para ello evidenciar que la caída de Interbolsa se generó, al parecer de algunos, por la desconfianza que se generó en el mercado de valores, a mediados del 2012, acerca de la mencionada Fabricato, lo que hizo imposible que Interbolsa siguiera realizando operaciones de repos con base a estas acciones. Esto quiere decir que pasaron años antes de que aún los sectores especializados (particularmente el bancario) descubrieran el engaño de Interbolsa. Y si este sector no podía ver lo que su-

11. Véanse las resoluciones 1795 y 1812 del 2012 de la Superintendencia Financiera de Colombia. 
cedía con claridad, mucho menos se puede esperar que lo hicieran los clientesinversionistas de Interbolsa, una sociedad vigilada con actividades claras y, particularmente, con promesas de ganancias que aún en el caso más extremo, no se acercaban al absurdo $4096 \%$ anual que implicaba el sistema de interés compuesto del esquema piramidal, que además no ofrecía a sus clientes (ni ellos la pedían) ninguna claridad sobre las actividades que realizaba para ofrecer tales dividendos.

\section{I.3 El problema}

Bien, teniendo presente el anterior contexto, se puede concretar que el problema científico a tratar, de manera general, es así: ¿Existe una decisión irracional del individuo al invertir en las pirámides o esquemas Ponzi, que contribuya a justificar la exoneración de responsabilidad del Estado? O por un mejor decir, ¿ existe una decisión irracional del individuo al invertir en las pirámides o esquemas Ponzi? Que de ser afirmativa la respuesta, ¿contribuya a justificar la exoneración de responsabilidad al Estado? En consecuencia, se deben tener como preguntas auxiliares: (i) ¿Qué es la racionalidad del individuo en el marco jurídico-económico?; (ii) ¿Qué son y cómo funcionan los esquemas Ponzi o piramidales?; (iii) ¿La decisión de inversión del individuo en los esquemas Ponzi o piramidales son un factor que contribuye a la exoneración de responsabilidad al Estado, conforme a sus consecuencias ${ }^{12}$, cuando aquellas colapsan económica y jurídicamente?

Así las cosas, la guía de desarrollo de la presente ponencia, al seguir las preguntas auxiliares, consistirá en: (i) Las normas jurídicas (formales) e instituciones informales como limitadoras y formadoras del juicio ${ }^{13}$, de los individuos en la toma de sus decisiones económicas: (ii) los esquemas Ponzi o

12. La declaración de responsabilidad estatal que otorgue el incentivo de indemnización a los afectados negativamente por las pirámides o esquemas Ponzi, puede dar lugar a un cambio en el juego de toma de decisiones racionales y contribuir a que el fenómeno se mantenga o reaparezca.

13. El juicio o la razón, es aquello que se encuentra mejor repartido entre los hombres y que permite diferenciar lo bueno de lo malo, conforme a los derroteros por el que se guie, racionalismo cartesiano. (Descartes, 1637). 
pirámides y la inversión del individuo; (iii) la crisis y la responsabilidad del Estado frente a los afectados y; (iv) conclusión.

\section{De la racionalidad económico-jurídica de los individuos}

La racionalidad se entiende como el proceso en un contexto de interacción, en el que conforme a un conjunto de decisiones posibles, sus consecuencias, el interés y beneficio de cada una de estas, el individuo adopta una en relación con su intencionalidad. En otras palabras, "[e]l principio de racionalidad interpreta las acciones individuales como acciones intencionales de los individuos. Invita a mirar la lógica del problema desde el punto de vista de los involucrados en esa decisión, en lugar de mirarlo desde afuera. Implica ponerse en el lugar del otro. Esto ha ayudado a entender muchos fenómenos en economía y ciencias sociales”(Streb, 1998, p. 11).

Ahora, en el contexto de interacción, los intereses, los beneficios y las consecuencias, debe considerarse que las normas jurídicas e instituciones informales son interiorizadas por las personas, las cuales asumen comportamientos conforme a la racionalidad de estas. En este sentido, se afirma que son las normas las que limitan la racionalidad de las personas siendo que puedan tomar una u otra decisión conforme a tal marco de derecho racional (Burgos Silva, 2002) ${ }^{14}$. Así, las normas jurídicas incorporadas a la racionalidad (Elster, Las limitaciones del paradigma de la elección racional, 2001) de la persona lo limitan en cuanto a entender que la maximización de su utilidad (intereses individuales) y reducción de sus costos se encuentra enmarcada por ciertos supuestos jurídicos (formales) e instituciones informales, en materia de inversiones.

\footnotetext{
14. El autor considera que una crítica a la NEI, es en cuanto no contempla que son las normas las que se incorporan al individuo, y este las obedece o no, porque las incorpora y acepta, siendo así que no persiga sus intereses individuales o sociales. Pues bien, consideramos que más que una crítica, esta debería ser una complementación, la cual debe entenderse así: Si las normas o instituciones son diseñadas para promover la eficiencia económica y estas son incorporadas y aceptadas por el individuos para conducir sus comportamientos, entonces, indefectiblemente estos actuaran dentro y en correspondencia con dichas normas en la toma de sus decisiones, pues se han limitado racionalmente mediante estas, para promover la eficiencia económica individual o social, según el enfoque dado por la política económica. Lo anterior, dentro de un marco de actuaciones racionales regulares.
} 
Es decir, que si un individuo ha incorporado las normas jurídicas e instituciones informales relativas a la rentabilidad de un capital invertido (máximos y mínimos de rentabilidad), se ha limitado racionalmente para entender que una alta rentabilidad en la inversión de un bajo capital, por lo menos le es sospechosa. Esto es, que al incorporar formal o informalmente lo relacionado con la rentabilidad y topes de la misma conforme al derecho y al contexto que lo rodea, se verá limitado en su racionalidad para comprender que la promesa de una rentabilidad, más allá de los topes, genera dudas.

Sin embargo, existe un afán de lucro en la sociedad moderna. La racionalidad se encuentra limitada, pero en ella intervienen aspectos no monetarios (incentivos en contextos de intereses individuales ${ }^{15}$ ) que se ponen en juego para tomar decisiones. Las ideas con las que interpretamos la realidad intervienen en la racionalidad limitada para la toma de decisiones. Así, una persona de bajos recursos puede buscar lucrarse de manera apresurada y desbordada, sin atender a la moralidad, e incluso, a la legalidad de los comportamientos desplegados para alcanzarla. Por el contrario, una persona acomodada, tenderá a realizar un mejor juicio de los comportamientos que pretenda realizar en el logro de aumentar sus recursos económicos, pues podría decirse que no está en situación de apremio. En suma, la racionalidad económica está constituida por el supuesto de la inteligencia analítica y la madurez emocional (Streb, 1998).

Esta circunstancia es uno de los aspectos más relevantes en la toma de decisiones. El apremio, la urgencia o la necesidad monetaria interviene de forma persuasiva al interior de la psiquis humana para contribuir a desconocer la racionalidad inicialmente limitada por el conocimiento del derecho racional. Así, la influencia que esta circunstancia produce en el pensamiento humano genera que se avizore la toma de mucho más riesgo y de decisiones que pro-

15. Conforme a las circunstancias y la cultura cada individuo puede definir y tomar intereses diversos, esto es, no solo económicos o monetarios, sino de tipo moral, por ejemplo. En este entendido, la racionalidad aplicada a maximizar la utilidad, no se reduce a solo económica, sino posiblemente moral, de tal forma que el individuo sea quien pondere cuál de ellas ha de prevalecer en determinado contexto y conforme a sus intereses. Los intereses individuales determinan la acción en búsqueda de recudir costos y maximizar la utilidad prevalente. 
duzcan consecuencias rápidas. Pues en definitiva se ha fijado el interés de satisfacer o conjurar inmediatamente la necesidad presente o a presentarse.

Otra circunstancia o factor es la confianza, la buena fe, la inocencia e incluso la convicción o auto-convicción (Salazar Trujillo \& Franco Escobar, $2009)^{16}$. En nuestra cultura, es ordinario observar aún cómo las personas confían, en materia de negocios, conducta que se perfila con base en el principio de buena fe. Aún más, en las clases sociales marginadas, baja y media baja se puede evidenciar, por parte de las personas, cierto grado de reverencia hacia quienes tiene una posición dominante en cuanto les son de utilidad. Es decir, en la mayoría de dichas clases sociales, las personas tienden a ser reverenciales frente a aquellos que ofrecen algún tipo de beneficio ${ }^{17}$. Confían en que alguien los beneficiara dándoles altas rentabilidades sobre la inversión del capital económico que poseen, en razón de que informalmente se han formado instituciones temporales que establecen la credibilidad de altas tasas de retorno y de oportunidad en los pagos de las mismas.

Entonces, la confianza, que se origina del cumplimiento de pagos oportunos de la alta rentabilidad prometida a los afiliados de los esquemas Ponzi o piramidales, información que se transporta mediante la red social. Es decir, información que llega al conocimiento, mediante la red social, y al convencimiento de aquellos que aún puedan estar considerando o pensando en inver-

\footnotetext{
16. “C ¿Cómo crece la pirámide? A través de los caminos que unen a los individuos de la red social en la que nace [pertenece y permanece]. La información que anuncia rentabilidades muy altas pasa a través de los vínculos familiares, amistosos y jerárquicos que unen a los individuos en su red social. Como se trata de una inversión que involucra riesgo, los vínculos no pueden se casuales o débiles: el que pasa la información elige al que la recibe y el que la recibe debe confiar en quien la entrega. El primero no pasa la información a cualquiera y el segundo no confía en su veracidad a menos que se trate de alguien cercano o con quien lo unen lazos de confianza. (...) Por esos caminos que unen a los individuos que forman la pirámide no solo circula información sobre a la existencia de ganancias por encima de lo normal. También circulan conjeturas respecto al estado de la inversión realizada”. (Salazar Trujillo \& Franco Escobar, 2009, pág. 90)

17. Un ejemplo claro, es la reverencia que siente y manifiesta una persona de estas clases sociales frente a aquel que ha ofrecido y dado trabajo. Esto es, que dicha persona siente (siquis) que la otra se encuentra en una posición dominante en cuanto le ha ofrecido y dado trabajo. Marcado comportamiento que se entiende por la marginación económica, social y cultural, pues de otra manera no se puede entender como en una relación como esta, que al ser recíproca, uno sienta y crea ser inferior al otro.
} 
tir. Así, un factor importante en la toma de decisiones es la información ${ }^{18}$ que se conoce para determinar el macizo de decisiones, del cual ha de tomarse o elegirse una.

Dichas circunstancias de apremio, confianza y desinformación se suman al incentivo de alta rentabilidad. De tal forma, el apremio, la confianza generada, la desinformación y el incentivo de altos rendimientos ${ }^{19}$, franquean de manera contundente la racionalidad limitada. Particularmente, la desinformación puede ser resultado también de un exceso de información cuya veracidad no puede ser evaluada por el receptor (Simon, 1971). Los usuarios de las pirámides se vieron enfrentados tanto a la falta (Elster, 1988) como al exceso de información cuando por una parte no encontraban certeza sobre las actividades de estas sociedades, y por otra parte eran inundados con testimonios de éxito de los primeros inversores de estos sistemas.

\section{Esquema Ponzi o piramidal}

La red social configura la estructura que sustenta el nacimiento y el desarrollo de las denominadas pirámides, pero dentro de estas opera una serie de procesos y relaciones racionales que pueden restringir, mantener o promover su crecimiento, permanencia o decrecimiento (Salazar Trujillo \& Franco Escobar, 2009, pp. 87-106). Por ejemplo, la falta de información formal, incluso de conocimiento ${ }^{20}$, genera que sea la red social la que forme y otorgue un criterio "racional”, al individuo, para la toma de decisiones de inversión en los esquemas Ponzi, los cuales, a su vez, se encargan de captar el buen ac-

\footnotetext{
18. Aun cuando la decisión perfecta mediante la racionalidad perfecta sea nugatoria debido a la complejidad que reviste la elección racional.

19. En el hombre moderno, predomina la acción hacia la maximización de utilidad económica.

20. La formación en análisis y matemáticas hace que se pueda tener presente la forma en que se determinara y tomara una decisión. La oleada o ronda de estafas mediante los Ponzi (Madoff), ha se ha logrado mediante la falta de conocimiento efectivo en la toma de decisiones. Veáse, Rapoport, Nancy, B. (2012), UNLV William S. Boyd, School of Golden Gate University Law Review , 42 pp. 627-640.
} 
tuar y el dinero de estos ${ }^{21}$. En este orden, no debe olvidarse que el ser humano tiende a querer creer que puede vencer las probabilidades adversas ${ }^{22}$.

Así, las pirámides están estructuradas en la participación, mediante la red social, de una cantidad considerable de individuos que realizan altas inversiones bajo las probabilidades de obtener altas tasa de retorno. Es decir, que aquel que invierte determinado dinero, tiene la expectativa de recibir un rendimiento proporcional o mayor. Así, el principal fundamento de las pirámides son aquellos dispuestos a contribuir con inversiones, pues la inversión de nuevos individuos permitirá el pago de los rendimientos prometidos, a aquellos participantes anteriores. En este sentido, se puede ver una redistribución de los capitales en función de aquellos que están en la punta de la pirámide y en desfavorabilidad de los que se encuentran en la base.

Ahora, un individuo que quiere invertir, encuentra que en las pirámides le es ofrecida una alta rentabilidad, sin embargo, corre el riesgo de perder su capital. Si decide invertir podrá perder lo invertido y ganar una alta rentabilidad, si decide no invertir conservara su capital, pero perderá la posible alta rentabilidad. Así las cosas, para que decida invertir debe existir un mínimo de confianza en relación con la obtención de una alta rentabilidad y la convicción de que conservará su capital invertido. De esta forma, se puede afirmar que la red social es aquella que permite que este tome la decisión de invertir, al igual que las posibles circunstancias de apremio. Ya que es la red social la que dota de la mínima confianza al potencial inversor en los esquemas Ponzi.

21. Las conjeturas colectivas formadas a través de la red social que trasporta la información sobre el pago y no pago de los intereses prometidos otorga un criterio de juicio al individuo sobre la viabilidad del esquema piramidal. (Salazar Trujillo \& Franco Escobar, 2009).

22. "Madoff sure seems to have known what he was doing. He cultivated the right people resource (letting him invest their money), and played into the natural human tendency to want to believe that they can beat the odds (with fake, double-digit, positive returns on phantom money)" (Rapoport, 2012, pág. 632). En este sentido, “[1]os primeros agentes en unirse a las pirámides tenían una alta probabilidad de recuperar su dinero con una ganancia, mientras que los situados en la base de la pirámide, dado el carácter especulativo del negocio, tenían una probabilidad más alta de perder su inversión al desmoronarse el sistema(Salazar Trujillo \& Franco Escobar, 2009, p. 88). 
Ahora bien, bajo los anteriores supuesto observar algunas posibles decisiones puede ayudarnos a entender este tipo de racionalidad en los esquemas Ponzi. Aquí Imaginemos que un individuo “ $x$ ” tiene un capital que desearía invertir, otro individuo “ $y$ ” invirtió su capital en una pirámide “ $p$ ”. Entonces, " $x$ " conforme a lo que ha evidenciado y escuchado ${ }^{23}$, si decidiera invertir en “p” recibiría 150\% de rentabilidad. Por otra parte, “y” está recibiendo el 150\% de rentabilidad por su inversión en “p”, y conoce el funcionamiento del esquema Ponzi. Así las cosas, nos encontramos frente a dos individuos que deben tomar decisiones conforme a su racionalidad.

Se representa, al interior y exterior de “p” así: (i) “ $x$ ” para invertir tiene como incentivo el $150 \%$ en rentabilidad; (ii) pueden no invertir y conservar su capital con $0 \%$ de rentabilidad; (iii) " $y$ " para retirarse tiene como incentivo el retorno de su capital más aquellos que alcanzo a recibir como rendimiento, durante determinado periodo de tiempo en el que estuvo vinculado a "p", que sea por ejemplo, $450 \%$ al ser mensual del 150\%; (iii) de no retirarse puede seguir percibiendo el $150 \%$ mensual, pero asumiendo un alto riesgo en el evento de una crisis el esquema Ponzi. Ambos sujetos tiene una situación de decisión, pero los diferencia la rentabilidad no recibida y ya recibida, el no estar vinculado con “p” y el estarlo, y el conocer o no que se trata de un esquema Ponzi o piramidal.

En este estado de cosas, puede definirse que existe un crecimiento exponencial definido dependiente, pues al ser la pirámide o esquema Ponzi un modelo que crece mediante la red social, en cuanto al número de participantes o inversionistas y, con ello, el crecimiento económico ${ }^{24}$, se define exponencialmente. Es decir, que el número de participantes definido por “ $\mathrm{X}$ ” establece el número de nuevos inversionistas, que es una variable al igual que el ex-

23. Recuérdese aquí que es incentivo informal para tomar su decisión conforme a la red social, circunstancias de apremio, rebasando los límites de su racionalidad formados por las instituciones formales (derecho).

24. Mediante la red social, se pueden presentar en los esquemas Ponzi o piramidales: (i) que un cada uno de los inversionistas logre atraer y vincular uno nuevo; (ii) que algunos inversionistas decidan reinvertir sus altos rendimientos, lo cual aumenta económicamente al esquema, pero no aumenta el número de participantes, sin embargo, aumentara su rentabilidad (otro incentivo). 
ponencial “n”. Entonces, se tiene Xn. Identificándose el probable crecimiento exponencial de participantes de la pirámide, mediante la red social, pero que no está sujeta a un crecimiento de inversionistas fijo, excepto que así se fijara. Sin embargo, si puede afirmarse que este crecimiento es finito, pues “ $x$ ” corresponde al número de participantes y " $n$ " al número de nuevos inversionistas, los cuales a la vez que se van aumentando, se van agotando en razón de la limitada red social, pues esta es la máxima población mundial, a menos que haga crisis a nivel local.

La crisis se presenta cuando se han agotado los participantes y con ellos las inversiones de capital, de tal forma que las altas rentabilidades prometidas y entregadas, empiecen a superar los ingresos netos por nuevas inversiones. En otros términos, el porcentaje de la tasa de entrada (\% Te) -nuevas inversiones- debe ser superior a " $k$ ", capital a pagar, constituido por el porcentaje de intereses promedio (\% Ip), más aquellos gastos de administración, comisiones u otros conceptos $(\mathrm{G})$. En términos generales, se define así: \% Te >k. Por una mejor expresión: \% Te $>\% \mathrm{Ip}+\mathrm{G}$.

En consecuencia, si \% Te $>\% \mathrm{Ip}+\mathrm{G}$, puede afirmarse que los esquemas Ponzi, no son imposibles, pero sí muy difíciles de mantener. Entre otros factores que inciden en que hagan crisis, son: los excesivos o altos rendimientos o tasas de retorno prometidos, pues la curva de crecimiento de los altos intereses a pagar se duplican exponencialmente, teniendo que buscar mayor cantidad -de la duplicación exponencial de intereses- de nuevos inversionistas y capitales a invertir y/o en razón del tiempo del pago de tales altos intereses. Así, teniendo la propiedad del número "e”, se formula que: “ $\mathrm{t}$ ", tiempo de duplicación $=\ln 2 / \mathrm{k}$, luego e $* 0,7 \neq 2(2,01375)$.

Por tanto, $\mathrm{t}=[70 /(\% \mathrm{Ip}+\% \mathrm{G})]$. En este entendido, quien lleva la dirección económica de la pirámide debe captar nuevos inversionistas que aporten un buen capital económico que permita ir remplazando el capital que se está pagando por concepto de intereses a los inversionistas, lo cual debe hacerlo tan rápido como resulte de la anterior formulación, pues de lo contrario 
iniciará el declive o crisis de la pirámide. Esto es, que no solamente económicamente hará crisis (aun cuando desde el inicio esté dada su fracaso), sino que a nivel del red social, que trasmite la información sobre el pago oportuno y efectivo de las altas tasas de retorno, comenzará la desconfianza para nuevos participantes y el retiro de los inversionistas ya vinculados.

Para ejemplificar lo anterior, tenemos $\mathrm{t}=[70 /(\% \mathrm{Ip}+\% \mathrm{G})$, entonces, consideremos que en un esquema Ponzi o piramidal se realizara la promesa de un $20 \%$ mensual a los inversionistas más $5 \%$ de gastos. Se tendrá: $\mathrm{t}=[70 /$ $(20 \%+\% 5 \%)=[70 /(25 \%)$, siendo que el director económico tenga que duplicar el capital de la pirámide cada 2,8 meses, para poder realizar los pagos a los inversionistas y realizar los gastos. Pero esto no es lo peor, pues cuando se precipite nuevamente a cero, deberá nuevamente en 2, 5 meses duplicar el capital de la pirámide en función exponencial, pues aumentaran las variables de inversionistas, las altas rentabilidades y los gastos ${ }^{25}$, consecuencia lógica de la función exponencial.

Un caso concreto y real en Colombia de esta situación, es evidente, como se mencionó, en el caso presentado para el año 2008, de la pirámide o esquema Ponzi denominada DRFE, que establecía una tabla de porcentajes de tasas de retorno y los días hábiles a ser pagados conforme al valor o cuantía del capital invertido ${ }^{26}$, notándose un incremento exponencial en el conjunto del esquema Ponzi y con base en la red social que le proveía la los nuevos incautos inversionistas, veamos:

\footnotetext{
25. Variables que son controlables por los fundadores, iniciadores, director o quien esté a cargo de la dirección económica de la pirámide o esquema Ponzi.

26. Véase, anexo sobre las promesas de alta rentabilidad o tasas de retorno y su función exponencial en DRFE, en Resolución No. 1778 de 2008, de la Superintendencia Financiera de Colombia.
} 


\begin{tabular}{|c|c|c|c|c|c|c|}
\hline 2008 & \multicolumn{2}{|c|}{ Pasto } & \multicolumn{2}{|c|}{ CALI } & \multicolumn{2}{|c|}{ POPAYÁN } \\
\hline MES & $\begin{array}{c}\text { No. } \\
\text { Recaudos }\end{array}$ & VALOR & $\begin{array}{c}\text { No. } \\
\text { Recaudos }\end{array}$ & VALOR & $\begin{array}{c}\text { No. } \\
\text { Recaudos }\end{array}$ & VALOR \\
\hline ABRIL & ○ & $\circ$ & ० & o & ० & $\mathrm{o}$ \\
\hline MAYO & 0 & $\circ$ & 0 & $\circ$ & o & $\circ$ \\
\hline JUNIO & ० & $\circ$ & 3 & $7,230,000.00$ & I & $200,000.00$ \\
\hline JULIO & $2 \mathrm{I}, 277$ & $74,470,556,547.00$ & $\mathrm{I}, 927$ & $7,201,993,380.00$ & 883 & $2,836,297,949.00$ \\
\hline AGOSTO & 29,0 I 4 & I $34,029,863,697.00$ & 7,067 & $29,196,909,875.00$ & 6,997 & $33, \mathrm{I} 53,494,582.00$ \\
\hline SEPTIEMBRE & ० & $\circ$ & 4,454 & $20,276,88 \mathrm{I}, 4 \mathrm{I} 4.00$ & 6,444 & 49,73 I $, 256,421.00$ \\
\hline TOTAL & $50,29 \mathrm{I}$ & $208,500,420,244.00$ & I 3,45 I & $56,683,014,669.00$ & 14,325 & $85,721,248,952.00$ \\
\hline
\end{tabular}

Tabla 1. Operaciones de recepción de dinero realizadas en sedes ubicadas en ciudades capital de departamento. Fuente: Tomado de SUPERINTENDENCIA FINANCIERA DE COLOMBIA, Resolución No. 1778 del 11 de noviembre de 2008 
Frente a esta evidencia se determina el crecimiento exponencial que tiene el esquema Ponzi en cuanto a los inversionistas que se van vinculando y en cuanto al aporte significativo que cada uno va realizando, generando un crecimiento exponencial en el capital de la pirámide. De tal manera, que funcione fundamentado en la información que circula en la red social de buenos pagos y pagos oportunos de las excesivas tasas de retorno. Así mismo, ha de predecirse la caída o crisis económica exponencial en la que entrará el esquema Ponzi o piramidal, en cuanto circule por la red social información de no pago, no pago oportuno o disminución en los pagos de las taladrantes tasas de retorno. Pues, como se ha formulado, el crecimiento y el equilibrio corresponde a duplicar exponencialmente dentro determinado tiempo los recursos económicos o capital de la pirámide.

Por consiguiente, la imposibilidad de mantener un equilibrio económico de la pirámide y el llegar a su crisis, genera que conforme a las decisiones de los sujetos, se ha evidenciado que dentro de las demandas más costosas, en términos monetarios por indemnizaciones, contra el Estado colombiano, se tienen aquellas justificadas en la garantía de vigilancia y control que debió tener el Estado, Superintendencia financiera y Superintendencia de Sociedades, en relación con las actividades adelantadas por las empresas captadoras masivas de dinero, o pirámides ${ }^{27}$. Así, hay quienes conocían el riesgo que presentaba invertir en un esquema Ponzi y había otros que, ignorantemente, desconocían que se encontraban realizando una inversión en un esquema Ponzi o piramidal. Sin embargo, ambos sujetos actuaron franqueando o desatendiendo la racionalidad limitada -por el derecho colombiano-, aunque en la actualidad manifiesten que se debe declarar la responsabilidad del Estado.

\section{I. Contribución a la exoneración de responsabilidad del Estado}

El derecho y el desarrollo, desde su paso por la teoría de la modernización hasta la Nueva Economía Institucional, ha mostrado como las instituciones

27. Tomado de: Referencia: http://www.elheraldo.co/local/las-25-demandas-mas-costosas-contra-el-estado-176694, [tomado el 19/03/15, a las 2:49 pm] 
jurídicas son un factor e incentivo para el desarrollo económico (Burgos Silva, $2002)^{28}$. Pues, para el caso anunciado, al ver que las instituciones jurídicas permiten, al estilo de un seguro de riesgo de inversiones, e incentivan a poder recuperar el dinero perdido mediante la declaración de responsabilidad del Estado, los individuos deciden buscar aumentar su utilidad económica, en circunstancias de pérdida, o restablecer la situación anterior ${ }^{29}$. Lo cual se evidencia en el surgimiento actual de nuevas pirámides y el reiterado acogimiento de los individuos ya no irracionales al momento de invertir.

Lo anterior debido a una institución formal, que consagra la obligación de vigilancia y control de las superintendencias, pero también influyen las instituciones informales que se generan mediante la cultura (Burgos Silva, 2002) -presumiblemente racional- que buscan la eficiencia económica de aquellos que intervienen en el mercado. Esta institución informal que va surgiendo lleva a los individuos a tomar una decisión de invertir. Las instituciones formales y las circunstancias concretas del individuo lo llevan a decidir en la inversión, aun cuando racionalmente conoce que está limitado por las normas jurídicas sobre rentabilidad de capital. Así, al decidir irracionalmente, busca justificar su actuar en que es el Estado quien debe garantizar la protección de su patrimonio, aun si lo ha gastado de manera irracional o fuera de la racionalidad limitada.

Pero surge aquí la pregunta de cuál debe ser esa protección que brinde el Estado al usuario de las Pirámides. En principio, los implicados alegan el deber de vigilancia del Estado, por parte de la Superintendencia Financiera, lo que implicaría que su protección debe ser la de los usuarios del sistema financiero. Realizaremos algunas consideraciones sobre este aspecto, para evidenciar que los distintos estándares de protección de los que pueda ser titular

28. El autor describe cómo desde una lectura parcial de Weber, en cuanto al derecho racional que dio surgimiento al capitalismo industrial en Europa, se formula, especialmente en EE.UU., un marco escaso en el que el sistema jurídico es el instrumento para obtener un desarrollo económico. El cual viene a ser retomado y superado por la Nueva Economía Institucional que nace en su decaimiento, sin dejar de observarse ciertas debilidades aún, en cuanto a este nuevo enfoque del derecho.

29. Este incentivo ha generado que el fenómeno de los esquemas Ponzi o piramidales en Colombia se esté presentando en la actualidad, como lo han advertido diferentes autoridades (Superintendencia financiera, de sociedades, medios masivos de comunicación, economistas, juristas, entre otros). 
el usuario de las pirámides, implica determinadas conductas de parte de este. Detallaremos estas conductas.

\section{El usuario como inversionista}

El diccionario de Oxford define al inversionista o inversor como la persona $\mathrm{u}$ organización que 'pone' dinero en un esquema financiero, propiedades, etc. con la expectativa de obtener un beneficio. En Colombia, es el Decreto 2080 de 2000, en su artículo $3^{\circ}$ el que desglosa una lista de actividades consideradas como inversiones. Aunque considera la categoría de inversión extranjera, este decreto concuerda con las definiciones internacionales de inversión, contenidas mayormente y con exceso de detalles en los llamados BIT (Bilateral Investment Treaties). La necesidad de definir lo que es una 'inversión' o quién se puede considerar un 'inversor' escapa a la normativa local por ser un concepto cuya aplicación jurídica coincide con la coloquial. Podemos tomar, como guía, las disposiciones de nuestro Código de Comercio cuando define el contrato de sociedad, como, aquel mediante el cual, dos o más personas se obligan a hacer un aporte en dinero, en trabajo o en otros bienes apreciables en dinero, con el fin de repartirse entre sí las utilidades obtenidas en la empresa o actividad social.

Esta definición es relevante porque, en palabras llanas, diferencia la actividad de los comerciantes-socios que, en determinada actividad, ponen trabajo, frente a aquellos que ponen dinero (o bienes). Los segundos, pues, son considerados inversionistas, lo que coincide con las disposiciones de los artículos 32, 88, 291, 446, y 474 del mismo Código. Es evidente que los usuarios de las pirámides deben ser considerados, entonces, inversores, pues su aportación a las actividades (presuntas) de estas empresas fue exclusivamente de capital.

Además, es diciente la siguiente consideración.

Que los “inversionistas” (como muchos de quienes depositaban sus ahorros de toda la vida se hacían llamar) ignoraban el negocio que estaba detrás de las pirámides no es sostenible, tanto 
por la conocida procedencia de sus fundadores, como por la región en donde surgieron. (Arteaga Moreno, 2009, p 5.)

Ahora bien, ya desde 1996 se viene haciendo una diferenciación entre inversionistas calificados y no calificados, resaltando la necesidad de proteger a los segundos. Evitando el desglose de la historia normativa, la nota vigente se encuentra en el decreto 2555 de 2010, que en su artículo 7.2.1.1.1. define al inversionista profesional como todo cliente que cuente con la experiencia y conocimientos necesarios para comprender, evaluar y gestionar adecuadamente los riesgos inherentes a cualquier decisión de inversión y, por exclusión, dispone en el artículo 7.2.1.1.4. que: Tendrán la categoría de "cliente inversionista" aquellos clientes que no tengan la calidad de "inversionista profesional”. Estas definiciones cobran relevancia al momento de comprobar en la norma mencionada múltiples grados de protección al cliente inversionista por considerarlo carente de la experiencia necesaria, estableciendo a su favor deberes de asesoría y garantía de condiciones de mercado, entre otros.

Sin embargo, al cotejar estas consideraciones con la normativa vigente sobre consumidores financieros y el Estatuto del Consumidor, encontramos que esta protección viene de la mano con un deber por parte del inversor. A saber, el deber de informarse, contenido en el artículo 2.2. del Estatuto del Consumidor y en el artículo 6.b. del Estatuto del Consumidor financiero, en el que se establece que debe ser práctica del usuario:

Informarse sobre los productos o servicios que piensa adquirir o emplear, indagando sobre las condiciones generales de la operación; es decir, los derechos, obligaciones, costos, exclusiones y restricciones aplicables al producto o servicio, exigiendo las explicaciones verbales y escritas necesarias, precisas y suficientes que le posibiliten la toma de decisiones informadas.

Esto porque toda inversión implica, por definición, un riesgo, como lo reconoce el mencionado Decreto 2555. Se pueden citar fuentes del Derecho 
Internacional que han dado mayores precisiones sobre este aspecto. El referente más claro proviene del Arbitraje Internacional en materia de Inversiones, campo de reconocida fecundidad en elaboración de jurisprudencia y doctrina en materia de Derecho de Inversiones. En este campo, es de particular importancia la definición que de inversión se dio en el caso Salini vs. Marruecos ${ }^{30}$ que ha llegado a considerarse como un test para definir la calidad de inversión de una actividad. Consideró el Tribunal en este caso que una inversión involucra aportaciones de capital; una cierta duración en la ejecución del contrato que da lugar o contiene la inversión; ingresos y beneficios regulares y la participación en los riesgos de la transacción.

Vemos, pues, que la actividad de los usuarios de las pirámides encaja a la perfección en la definición doctrinal de inversionista, a excepción, según lo quieren hacer parecer estos usuarios, del riesgo asumido.

\section{El usuario como consumidor}

Ahora bien, hemos establecido como hipótesis que los ciudadanos que invirtieron su dinero en las pirámides se deben considerar como tales, y hemos extraído las correspondientes conclusiones que acabamos de tratar. Queda solamente demostrar que aún por fuera de nuestra hipótesis fuerte, los ciudadanos, bajo cualquier título considerados, son los únicos responsables por sus pérdidas. Nuestra primera fuente es el Código de Comercio, que en su artículo 11 dispone que "Las personas que ejecuten ocasionalmente operaciones mercantiles no se considerarán comerciantes, pero estarán sujetas a las normas comerciales en cuanto a dichas operaciones”.

Sin necesidad de definir a los 'usuarios' como inversionistas ni comerciantes, hemos de aceptar que la operación de invertir su dinero en los esquemas Ponzi fue, a todas luces, comercial (a sa-

30. Salini CostruttoriS.p.A. and ItalstradeS.p.A. v. Kingdom of Morocco (ICSID Case No.ARB/00/4) Decisión sobre jurisdicción. 
ber, motivada por el deseo de obtener una ganancia, y no por la mera liberalidad) y queda enmarcada en los numerales 4, 6 y 7 del artículo 20 del mismo código, así como en lo dispuesto en el Título III de su LIBRO TERCERO y en las disposiciones generales del LIBRO CUARTO. Si se requiere mayor precisión, establece el artículo 22 que "Si el acto fuere mercantil para una de las partes se regirá por las disposiciones de la ley comercial".

Es imposible negar, en última instancia, que al menos una de las partes consideraba su actividad como comercial. Pues bien, dentro de este considerando, es bien sabido que se exige del comerciante o de aquel que comercie, que se comporte — valga la redundancia—como comerciante. Es decir, que habrá de actuar en protección de sus propios intereses con la responsabilidad debida de quien se pone en riesgo al momento de realizar una actividad comercial.

Puede extenderse la exposición. Las breves líneas anteriores no dejan claridad sobre el régimen de responsabilidad que habría de tenerse en cuenta bajo la hipótesis de que los 'usuarios' de las pirámides se consideren comerciantes. Consideramos, sin embargo, que no resulta extraña para el lector la idea de que un comerciante está obligado a actuar racionalmente, y remitimos al artículo 12 del Código de Comercio como testimonio de lo expuesto.

En realidad, nos interesa en este aparte analizar un caso extremo. Analizaremos la hipótesis de considerar al 'usuario' de las pirámides como un consumidor a.) Financiero, o b.) Amparado por el Estatuto del Consumidor. Conocemos, por supuesto, que los regímenes de protección al consumidor y al consumidor financiero no se encontraban vigentes para el momento de la crisis del 2008. Sin embargo es nuestro propósito demostrar que aún bajo hipótesis tan débiles, los 'usuarios' de las pirámides son los únicos responsables por sus pérdidas. Sobra, sin duda, aclarar el por qué consideramos esta como una hipótesis débil. El régimen de los consumidores es garante y proteccionista frente a los 'usuarios' si consideramos que se pueden amparar en ellos. 
Ambos regímenes parten de supuestos comunes como son:

1. El consumidor no es un experto en ninguna rama del comercio, mientras que su contraparte (según el régimen) conoce y puede aprovecharse de sus conocimientos sobre un determinado ramo comercial (por ejemplo, el responsable de la pirámide podrá engañar al consumidor). Esto implica que;

2. El consumidor se encuentra en desventaja al momento de contratar, le resulta imposible conocer, en detalle, las implicaciones que tiene la manifestación de su voluntad al momento de obligarse (por ejemplo, desconocería los avatares del mercado al momento de 'entregar' su dinero en las pirámides) y por lo tanto;

3. El Estado debe brindar especial protección a los consumidores, y como corolario de esto;

4. El Estado es responsable por los daños causados al consumidor, cuando incumple su deber de protegerle (por ejemplo, cuando falla en la vigilancia de las sociedades que encubren sistemas piramidales)

Ahora bien, si analizamos las definiciones de ambas normativas podemos encuadrar la calidad de los usuarios de las pirámides en dichas disposiciones. Así, el artículo 5.3. de la Ley 1480 nos dice que el consumidor es

Toda persona natural o jurídica que, como destinatario final, adquiera, disfrute o utilice un determinado producto, cualquiera que sea su naturaleza para la satisfacción de una necesidad propia, privada, familiar o doméstica y empresarial cuando no esté ligada intrínsecamente a su actividad económica. Se entenderá incluido en el concepto de consumidor el de usuario.

Por su parte, el artículo 2.d. de la Ley 1328 nos dice que es consumidor financiero "todo cliente, usuario o cliente potencial de las entidades vigiladas".

Ya que se ha cuestionado el papel de los organismos de vigilancia frente a estas entidades, podemos considerar, en pos de un 
mejor análisis, la hipótesis de que el usuario, cliente o cliente potencial de una entidad que 'debería ser vigilada' también encaja en esta definición, y en consecuencia merece protección.

Sin embargo, como hemos mencionado antes, esta protección, último punto mencionado, viene de la mano de un deber de informarse por parte de los consumidores y usuarios del sistema financiero. Recuérdese, por ejemplo, que según las disposiciones del artículo 6 del Estatuto de la Ley 1328 de 2009, son prácticas del consumidor financiero

a. Cerciorarse si la entidad con la cual desean contratar o utilizar los productos o servicios se encuentre autorizada y vigilada por la $\mathrm{Su}-$ perintendencia Financiera de Colombia.

b. Informarse sobre los productos o servicios que piensa adquirir o emplear, indagando sobre las condiciones generales de la operación; es decir, los derechos, obligaciones, costos, exclusiones y restricciones aplicables al producto o servicio, exigiendo las explicaciones verbales y escritas necesarias, precisas y suficientes que le posibiliten la toma de decisiones informadas.

$[\ldots]$

d. Revisar los términos y condiciones del respectivo contrato y sus anexos, así como conservar las copias que se le suministren de dichos documentos.

e. Informarse sobre los órganos y medios de que dispone la entidad para presentar peticiones, solicitudes, quejas o reclamos. $[\ldots]$

Concluimos en este acápite que si el usuario es racional, como lo hemos considerado y sin importar el régimen al que quede supeditado, tiene deberes claros que le impiden actuar de manera imprudente al momento de invertir en las pirámides. Al margen del cumplimiento de estas obligaciones, es ilógico que espere del Estado la restitución de su inversión. Además, si observamos la distinción entre inversores profesionales y clientes inversores del Decreto 
2555 , observamos que el ordenamiento reconoce la posibilidad de que el inversor actúe sin los conocimientos suficientes sobre la materia, como lo habíamos preguntado a los usuarios 'de buena fe' de las pirámides. Pero la falta de información, educación, o la necesidad, no equivalen a la irracionalidad, y mal haría el Estado en aceptar estas condiciones como suficientes para resarcir a los clientes de las pirámides, pues hacerlo no hace más que incentivar el surgimiento de los esquemas Ponzi, como pasamos a exponer en nuestro último contenido.

\section{Las consecuencias de la responsabilidad del Estado}

Decidir en la condena del Estado por considerarse responsable, genera un incentivo institucional formal que demostrará porqué el fenómeno se vuelve a presentar. Este incentivo cambia las reglas de juego iniciales a las que el individuo temía, porque no tenía sino un mínimo de confianza y un alto riesgo de pérdida del capital invertido en las pirámides. Además, esta información, tanto de cómo funcionan los esquemas Ponzi, por ya haber sucedido, como de saber que conforme a una institución formal podrá recuperar su capital invertido, genera un cambio en las reglas de juego que incentivan a la inversión sin apreciación del riesgo, en confianza de no perder lo invertido.

Es decir que el incentivo formal se contrapone al incentivo negativo del suceso ocurrido. En primer lugar la pérdida de capital desincentiva al inversor y lo empuja a limitar su racionalidad en cuanto a la rentabilidad jurídicamente posible de su dinero. Sin embargo, al condenarse al Estado por estos hechos, se superpone un incentivo que anula el anterior y genera un estado peor que el precedente, pues si al inicio asumía un riesgo en el grado de confianza mínimo de invertir en estos esquemas, actualmente toma la decisión de invertir en los Ponzi, totalmente confiado y sin asumir riesgo alguno. En este sentido, una acción irracional del individuo al invertir en los esquemas Ponzi, es validada, reafirmada e incentivada posteriormente por otra decisión irracional del Estado; quebrantándose con esta declaratoria de responsabilidad Estatal y la 
correspondiente indemnización o devolución de dineros, el principio de la racionalidad que está dado en los pagos que se hacen para crear una eficiencia individual y colectiva.

En este orden, al ser el derecho (Constitución, Leyes, decisiones jurisprudenciales $^{31}$, actos administrativos, reglamentos, estatutos, entre otras) irracional, se obtienen efectos colectivos deficientes. En otras palabras "para que exista un resultado que sea ineficiente a nivel colectivo, parece ser relevante una perspectiva de racionalidad limitada" (Streb, 1998, p. 8).

Los pagos que se realizan por el seguimiento o la infracción de las leyes afectan las opciones que tiene el individuo para jugar. Dichas leyes formales e informales son aquellas que están incorporadas en la racionalidad del individuo en su convivencia habitual y constante en determinado contexto. Estas presuponen un marco institucional formal e informal en el que se determina el juego en el que participa el individuo. Por tanto, un cambio en las instituciones implica un cambio en el juego. En otros términos:

La manera en que las leyes actúan no es tanto afectando las opciones abiertas a los individuos, sino afectando los pagos de cada opción, al imponer ciertas consecuencias a las acciones de los individuos. Si bien el marco legal prohíbe ciertas acciones, lo que en principio hace el sistema legal en sí es aplicar un castigo cuando se transgrede una prohibición. En el dilema del prisionero, las decisiones individuales presuponen leyes formales e informales, que están implícitas en un segundo plano. Este conjunto legal y para-legal determina un marco institucional, que se puede pensar como las reglas que definen qué se va a jugar. Un cambio de reglas lleva a un cambio de juego. En consecuencia, se puede pensar en los marcos institucionales desde el punto de vista de a qué equilibrios llevan. Un resultado socialmente ineficiente puede tratar de subsanarse con un cambio institucional. (Streb, 1998, p. 8).

31. Es de anotar que el sistema jurídico colombiano es continental, sin embargo, con el paso del tiempo y el activismo judicial, las decisiones de los jueces han tomado tal fuerza vinculante que en la actualidad existe precedente vertical y horizontal en el cual se establece el marco de una sobra decisional, que el apartarse de ella requiere de una sólida carga argumentativa. (Lopez Medina, 2006) 
Bajo este presupuesto, el surgimiento de un cambio institucional formal en el que se incentiva la inversión en las pirámides genera un nuevo juego para el individuo. Este puede ilustrarse al tener la unidad que representa el valor a invertir en los esquemas Ponzi por el individuo, relacionada recíproca y proporcionalmente a la unidad a indemnizar por parte del Estado al individuo. Se tiene un juego como este:

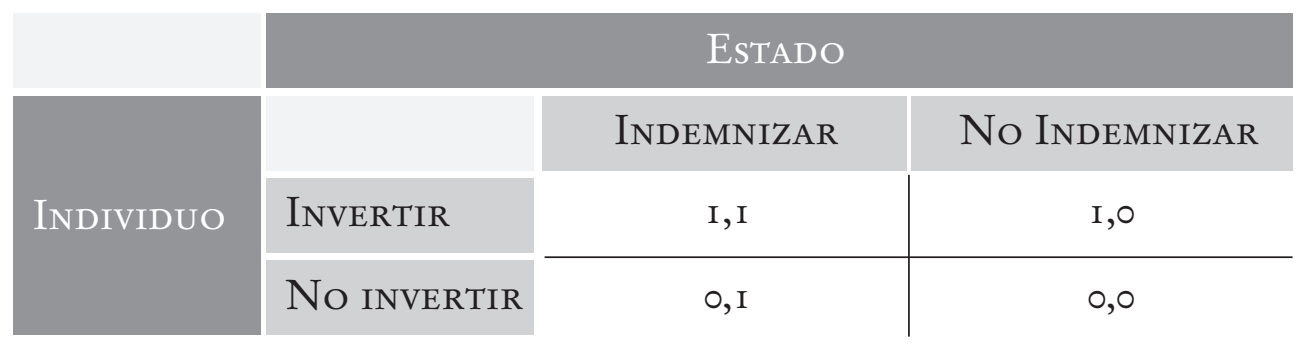

Tabla 2. Juego 1. Fuente: Elaboración propia

La estrategia conforme al juego determina que la decisión más irracional es el tercer cuadrante ${ }^{32}$, el equilibrio se evidencia en 0,0 . El incentivo negativo en 1,0 y el incentivo positivo en el 1,1.

Es decir, una vez se presenta el fenómeno de surgimiento, inversión, desarrollo y crisis de las pirámides teniendo presente las decisiones individuales y luego, por interacción, múltiples ${ }^{33}$, el juego se puede presentar entre Estado e individuos, así: (i) el Estado procede a reparar a aquellos individuovictimas que han invertido $(1,1$,$) . Aquí se estimula el surgimiento de nuevas$ pirámides pues se recibirá indemnización por dicha decisión irracional, pero para este nuevo escenario, racional $^{34}$; (ii) si no se falla la declaración de responsabilidad del Estado para reparar a los inversionistas-víctimas de las pi-

\footnotetext{
32. Desde la parte superior, de izquierda a derecha, pasando a la inferior; de izquierda a derecha.

33. (Hammond, 1998) In the rational decision theory are important the measurable objectives, for example, in the companies' people should approach to measurable targets, or objectives and behavior according to they.

34. Para cuando el fenómeno se presenta de nuevo, las reglas de juego han cambiado y la decisión de invertir nuevamente en los esquemas Ponzi se vuelve racional para el individuo, pues ya se ha conjurado el riesgo.
} 
rámides $(1,0)$ se disuade al individuo para que no se presente nuevamente el fenómeno. El incentivo es negativo en cuanto ejemplifica que no se recuperará por vía de reparación estatal el capital invertido irracionalmente por parte del individuo; (iii) seguidamente, conforme al incentivo negativo, se presentara un equilibrio en el que ninguno, individuo y Estado, decidan invertir e indemnizar, respectivamente $(0,0)$. Este es el equilibrio por el que se debió abogar desde la academia y jurisprudencia, desde el conocimiento público de las pirámides o esquemas Ponzi en Colombia hacia el año 2008, lo cual no se consideró. Pues actualmente, se han mantenido o presentado nuevos fenómenos de esquemas Ponzi o piramidales en Colombia ${ }^{35}$.

Una analogía interesante puede encontrarse en el título del libro de Jon Elster (1997): "Ulises y las Sirenas, Estudios sobre racionalidad e irracionalidad”. En él, como lo hemos hecho nosotros, el autor reconoce la diferencia entre la racionalidad perfecta y la racionalidad específicamente humana. Ulises, muestra el autor, sabe de la flaqueza de su voluntad (que limita su racionalidad) y en consecuencia prefiere atarse al mástil de su barco y cubrir sus oídos con cera antes de enfrentarse al canto de las sirenas. Ulises sabe que dejarse llevar por su canto es irracional, y lo conducirá a la muerte, pero sabe también que no podría evitarlo por cuenta propia. Para nuestro caso, los usuarios de las pirámides reconocen que el riesgo de invertir en estos sistemas puede acarrearles grandes pérdidas, pero en vez de atarse al mástil, invertirán en ellas si existe una promesa de retribución por parte del Estado.

Esta idea redunda, para Elster, en una serie de mecanismos llamados 'compromisos previos' que se establecen por el intento del individuo que desea ser racional a sabiendas de que su irracionalidad le acarrea perjuicios. Ejemplo en el derecho de estos compromisos previos, son las constituciones nacionales ${ }^{36}$, que contienen tanto normas escritas como convenciones constitucionales, normas no escritas pero aplicables por la existencia de una cono-

35. Así lo confirma, el boletín de la Superintendencia de Sociedades el pasado mes de febrero de 2015.

36. El impacto de las constituciones en el desempeño económico 
cida consecuencia por su incumplimiento. El paralelismo con nuestro caso es evidente. Sea a través de normas escritas o la práctica jurisprudencial, es necesario que se genere en los ciudadanos un 'compromiso previo', un mecanismo que los empuje a tomar decisiones racionales frente a la aparición de sistemas piramidales. Evidentemente, este objetivo no se cumple si el usuario de las pirámides encuentra que su inversión está protegida por el Estado. El mástil de Ulises incluye, sin duda, la vigilancia del Estado de este tipo de sociedades, pero es el usuario el que debe atar las sogas que le impidan invertir en ellas. Si los ciudadanos no cumplen con este deber de diligencia, no habrá vigilancia de parte del Estado que impida el resurgimiento (una y otra vez) de los esquemas Ponzi. 


\section{Conclusiones}

La racionalidad limita el acelerado escalonar económico. Las pirámides o esquemas Ponzi en Colombia y su surgimiento y exterminio, pudo haberse dado después del año 2008. La política errónea del Estado las ha revivido para la actualidad. Una pirámide es una estructura social que se sumerge en una red social, de la cual aprovecha la información, relaciones, expectativas económicas de los individuos -su motor económico- y las circunstancias que franquean la racionalidad limitada del individuo, aun colectiva ${ }^{37}$. Por tanto, la decisión de invertir en una pirámide o esquema Ponzi se torna irracional en cuanto franquea por diversas circunstancias la racionalidad limitada-derecho-. Dicha decisión irracional no puede ser usada como premisa para la declaración de responsabilidad del Estado y, por ende, lograr una indemnización que lleve a la recuperación del capital invertido. Tomar una decisión o fallo de esta manera, configura una institución formal que modifica las condiciones y reglas de juego del individuo, que optará en este nuevo escenario por invertir nuevamente en el esquema piramidal o Ponzi. Dando como resultado que se incentive y se fortalezca el marco jurídico, económico y racional para que sigan apareciendo estos esquemas fraudulentos e ilegales.

Ahora, como habíamos diferenciado en la síntesis de este escrito, se puede clasificar en dos el tipo de inversionistas: los racionales que retiran su capital antes de que colase la pirámide, pues tiene conocimiento, siquiera, intuitivo de ello, y los inversionistas irracionales, aquellos que por falta de educación e información toman, lo que se considera una decisión irracional y no piensan en retirar el capital invertido. Estos últimos, conforme a la irracionalidad del derecho colombiano -declaración de la responsabilidad del Estadoresultaron mejor favorecidos que los primeros.

Lo anterior, se explica en el sentido de que la decisión judicial de la declaración o no de responsabilidad del Estado por el fraude de los esquemas

37. "Una pirámide, entonces, es una estructura social temporal incrustada en una red social más amplia, a la que "explota”, en términos de contactos e información, para crecer" (Salazar Trujillo \& Franco Escobar, 2009, p. 90). 
Ponzi en Colombia, hace que se cambien los incentivos o consecuencias de las decisiones posibles que el individuo puede tomar para buscar un equilibrio. Por ejemplo, si a una víctima de las pirámides se le otorga una indemnización, esto altera el juego en el sentido de que dará al individuo, en la toma de sus decisiones, un incentivo para adoptar una decisión de inversión con consecuencias benéficas y no negativas, como no debe ser. Así se incentiva para que el fenómeno se vuelva a presentar. Una vez que se presenta por primera vez o por segunda, o sucesivamente, se puede determinar la mala fe de aquellos -inversionistas reincidentes- que conforme a las nuevas reglas del juego y frente a la información, están tomando, como altas tasas de retorno, el capital de otro. De tal manera, que sea capaz de retirarse en el momento oportuno o que espere la reparación estatal (Gabel, 2012). Aun cuando son decisiones racionales y legales conforme al marco jurídico dado, son actuaciones de mala fe promovidas por el Estado.

Entonces, la promesa de altas rentabilidades, esto es, por encima de la inflación y sin fluctuaciones, que franquean por diferentes circunstancias la racionalidad limitada, pasa a ser responsabilidad del individuo que decide invertir en los esquemas Ponzi o piramidales, pues es quien asume el riesgo limitado por la racionalidad del derecho. Sin embargo, al otorgársele, de forma irracional, a este un incentivo de indemnización, por la declaración de responsabilidad del Estado, cambia las reglas de juego y su nueva decisión de invertir en las pirámides dejara de franquear la racionalidad limitada inicial. Así, dicho incentivo pasará a ser parte de su racionalidad limitada y su nueva decisión será racional, pues es el Estado, mediante una decisión irracional, el que ha incorporado una nueva regla de juego posibilitando un nuevo proceso de elección racional.

Basta, para terminar, hacer hincapié en que nuestra posición se ha venido tomando desde tiempo atrás cuando, haciendo un análisis de la normativa expedida en respuesta al fenómeno de las pirámides, se dijo que:

Tampoco puede perderse de vista que si bien el objeto de la disposición es resguardar el orden económico social, resulta protegiendo a ciudadanos 
que están al margen de la ley, toda vez que llevan sus dineros a personas no autorizadas, en procura de mayores intereses de los concedidos por el sector financiero y, especialmente, para no cancelar las obligaciones tributarias que resultan de obtener esas ganancias, manteniendo - de hecho- esos recursos ocultos al gobierno. Empero, una vez sufren el desmedro de su patrimonio, corren apresuradamente a la justicia para que les ayude a recuperar el dinero que habían sustraído a la actividad económica del país (Hernández Quintero, 2009, p.10). 


\section{Referencias}

Acero, Y., López, C., \& Prieto, M. (2012). Análisis y recomendaciones al estatuto del consumidor Ley 1480 de 2011 en el marco normativo del derecho español. Bogotá: Pontificia Universidad Javeriana. Especialización de Derecho Comercial.

Alessandri, A. (1981). De la responsabilidad extracontractual en el derecho civil. Santiago de Chile: Imprenta Universal.

Álfaro, Á.-R. (2002). Función Económica y naturaleza jurídica de las condiciones generales. En M. M. Díez-Picazo, Comentarios a la Ley sobre condiciones generales de la contratación (pág. 81 ss). Madrid: Civitas.

Almanza, C. P. (2012). La libertad de competencia en los procesos de selección objetiva. 2012: Universidad Externado de Colombia.

Alonso Pérez, M. (2004). Aproximaciones a la idea de contrato (Apoteosis $y$ declive de la autonomía privada). Responsa Iurisperitorum Digesta. Alterini, A. (2007). Estudios en Derecho Civil: Conceptos, contraos, consumidor, derecho. Buenos Aires: La Ley.

Anaya, C. (2012). Riesgos en las transacciones electrónicas bancarias. Una carga que debe ser asumida por la banca. Mercatoria. Mercatoria, 287-331.

Arteaga Moreno, L. H. (2009). El cartel de la estafa. Pasto: Universidad San Martin.

Bohórquez Orduz, A. (2009). De los negocios jurídicos en el derecho privado colombiano. Bogotá: Ediciones Doctrina y Ley.

Buchaman, J. M. (2009). Los limites de la libertad, entre la anarquía y el leviatán. Madrid: Katz Editores.

Burgos Silva, G. (2002). Derecho y desarrollo económico: de la Teoría de la modernización a la Nueva Economía Institucional. Revista de Economía Instituciona vol. 04- No 07, segundo semestre. 
Camacho, E. M. (2015). MANUAL DE CONTRATACIÓN DE LA ADMINISTRACIÓN PÚBLICA:REFORMA DE LA LEY 80 DE 1993. Bogotá: Universidad Externado de Colombia.

Cárdenas Mejía, J. P. (1999). Justicia Contractual. En M. e. Plazas Vega, Derecho Civil y Comercial (pág. 301 ss). Bogotá: Ediciones Rosaristas, Dike.

Colombia, Congreso de la Republica. (12 de Octubre de 2011). Ley 1480 "Por medio de la cual se expide el Estatuto del Consumidor y se dictan otras disposiciones.". Diario Oficial No. 48.220.

Colombia, Ministerio de Comercio Industria y Turismo. (26 de Octubre de 2012). Decreto 2184. MIN. Fernando CArillo., Bogotá D.C.

Comercio, S. d. (2010). Guía Práctica para Combatir la Colusión en las Licitaciones. Bogotá: Superintendencia de Industria y Comercio.

ConsejodeEstado. (2013). Ciarquelet Ltda. Vs. Distrito Capital Departamento Administrativo de Acción Comunal Distrital y Consorcio Comunidad y Construcción. Sentencia Sección Tercera, Subsección A, Sala de lo Contencioso Administrativo., 34.

Corte Constitucional. (2000). Sentencia C-662. Magistrado Ponente Fabio Morón Diaz. Bogotá: Corte Constitucional.

Corte Constitucional. (2002). Sentencia C-973. Bogotá.

Decreto 1441. (1982). Por el cual se regula la organización, el reconocimiento y el régimen de control y vigilancia de las ligas y asociaciones de consumidores y se dictan otras disposiciones. Bogotá: Presidencia de la República.

Decreto 3466. (1982). Por el cual se dictan normas relativas a la idoneidad, la calidad, las garantias, las marcas, las leyendas, las propagandas y la fijación pública de precios de bienes y servicios, la responsabilidad de sus productores, expendedores y y se dictan otras dis. Bogotá: Presidencia de la República.

Development, O. f.-o. (2010). ROUNDTABLE ON COLLUSION AND CORRUPTION IN PUBLIC PROCUREMENT. París: OCDE. Díez- Picazo, L., Roca Trias, E., \& Morales, A. (2002). Los principios del Derecho Europeo de Contratos. Madrid: Civitas. 
Diez, L. (1999). Derecho de años. Madrid: Civitas.

Díez-Picazo, L. (1979). Derecho y Masificación social, Tecnología y Derecho Privado. Madrid : Civitas.

Elster, J. (1988). Uvas Amargas. Sobre la subversión de la racionalidad. Barcelon: Peninsula.

Elster, J. (1997). Ulises y las Sirenas, Estudios sobre racionalidad e irracionalidad. Mexico: Fondo de Cultura Económica.

Elster, J. (2001). Las limitaciones del paradigma de la elección racional. Valencia: Institución Alfonso el Magnànim.

Embid Irujo, J. M. (2002). Comentarios a la Ley de Contratos de Seguro. Valencia: Tirant lo Blanch.

Freud, S. (2000). Psicología de Masas; más allá del Placer; El porvenir de una ilusión. Barcelona: Alianza.

Gabel, J. D. (2012). Midnight in the Garden of Good Faith: Using Clawback Actions to Harvest Equitable Roots of Bankrupt Ponzi Schemes. Georfia State university College of Law.

Galvis-Quintero, D. (2016). LA COLUSIÓN COMO UNA PRÁCTICA RESTRICTIVA DE LA COMPETENCIA QUE AFECTA GRAVEMENTE LOS PROCESOS DE SELECCIÓN DE CONTRATISTAS. Vniversitas, 133-196.

García Amigo, M. (1969). Condiciones Generales de los Contratos. Revista de Derecho Privado, 160 ss.

Gómez-Lee, I. D. (2010). Contratación visible, Manual para un buen control de recursos en la contratación pública. Bogotá: Auditoría General de la República en coedición con el Instituto de Estudios.

Gozálvez, C. (1992). En B. Rodríguez-Cano, Comentarios a la Ley General para la defensa de los consumidores y usuarios. Madrid: Civitas.

Hammond, P. J. (1998). Rationality in economics. Stanford University.

Hernandez Quintero, H. A. (2009). De las pirámides al delito del Ejercicio Ilegal de la Actividad Financiera. Bogotá.

Hierro, L. (2001). La responsabilidad en el Derecho. investigación sobre el concepto jurídico de responsabilidad. En F. Pantaleón (Ed.), Anuario de la facultad de derecho de la Universidad Autónoma de Madrid. Madrid: Universidad Autónoma de Madrid. 
Hinestrosa, F. (1986). Estudios de derecho privado: homenaje al Externado en su centenario. Bogotá: Universidad Externado de Colombia.

Janis, I. L. (1982). Groupthink: psychological studies of policy decisions and fiascoes. Boston: Houghton Mifflin .

Jaramillo J, C. I. (2015). La Compraventa en el Derecho de Consumo. Bogotá: Ibañez.

Kahneman, D. (1982). Judgment under uncertainty :heuristics and biases. Cambridge: Cambridge University Press 1982.

Lacayo, M. A. (2015). Condiciones Generales de la Contratación, una perspectiva de la buena fe en el control de incorporación. Bogotá: Ibañez.

Larenz, K. (2002). Base del negocio jurídico y cumplimiento de los contratos. Granada: Comares.

Latané, B. (1981). The psychology of social impact. American Psychologist, 36, 343-356.

Ley 1480. (2011). Por la cual se dictan normas relativas a la idoneidad, la calidad, las garantias, las marcas, las leyendas, las propagandas, la fijación pública de precios de bienes y servicios, y la responsabilidad de sus productores, expendedores y proveedores. Bogotá: Congreso de la República.

Ley 446. (1998). Por la cual se adoptan como legislación permanente algunas normas del Decreto 2651 de 1991, se modifican algunas del Código de Procedimiento Civil, se derogan otras de la Ley 23 de 1991 y del Decreto 2279 de 1989, se modifican y expiden normas del Código. Bogotá: Congreso de la República.

Llodrá Grimalt, F. (2002). El contrato celebrado bajo condiciones generales. Valencia: Tirant lo Blanch.

Lopez Medina, D. (2006). El Derecho de los Jueces. Bogotá: Universidad de los Andes.

Martínez Martín, M. (1996). Comentarios a la Sentencia de 13 de noviembre de 1995. ADC No. 41, 596.

Monroy Cabra, M. G. (2002). Derecho internacional público. Bogotá: Temis. 
Moore, J. (2012). Cartels Facing Competition in Public Procurement: An Empirical Analysis. Institut d'Administration des Entreprises.

Moreno, J. A. (2007). La responsabilidad civil y su problemática actual. Madrid: Editorial Dikinson.

Myers, D. G. (2010). Social Psychology. New York: McGraw-Hill.

OCDE. (2013). Combate a la Colusión en los Procesos de Contratación Pública en México. París: OCDE.

OECD, T. O.-o. (2010). Collusion and Corruption in Public Procurement. París: OECD.

Ospina Fernández, G. (2014). Teoría General del Contrato y del Negocio Jurídico. Bogotá: Temis.

Ospina, G. (1998). Régimen general de las obligaciones. Bogotá: Temis.

Ossa, C. E. (2014). Tratamiento de la colusión en la contratación pública: una visión del caso colombiano. REVISTA DE DERECHO universidad del norte.

Pagador López, J. (1999). Las condiciones generales de la contratación: introducción y régimen jurídico de los contratos celebrados mediante ellas. En G. Botana, \& M. Ruiz, Curso sobre protección jurídica de los consumidores. Madrid: McGraw Hill.

Peñalosa, E. J. (2010). Novedades de la Ley 1340 de 2009 para el régimen de protección de la competencia. Revista Contexto.

Peñalosa, E. J., \& Pabón Almanza, C. (2012). Colusión en licitaciones El caso paradigmático para las entidades públicas. Revista de derecho y economía, 9-32.

Quijano, J. P. (1999). Manual de derecho probatorio. Bogotá: Ediciones Librería del Profesional.

Rapoport, N. (2012). Black Swans, Ortriches, and Ponzi Schemes. Golden Gate University Law Review, 627-640.

Rodríguez Yong, C. A. (2013). Una aproximación a las cláusulas abusivas. Bogotá: Legis.

Salazar Trujillo, B., \& Franco Escobar, A. M. (2009). El juego de las pirámides. (U. d. Valle, Ed.) Revista de Sociedad y Economía, 16, 87106. 
Sanchez, J. A. (28 de abril de 2003). Análisis del mercado de operaciones repos y simultáneas sobre deuda pública española. 2767.

Santofimio, J. O., \& Benavides, J. L. (2009). Contratación estatal. Estudios sobre la reforma del Estatuto Contractual. Ley 1150 de 2007. Bogotá: Universidad Externado de Colombia.

Sentencia del 24 de agosto. (2009). Sentencia del 24 de agosto de 2009. Bogotá: Corte Suprema de Justicia.

Simon, H. A. (1971). Designing Organizations for an Information-Rich World. En M. Greenberg, Computers, Communication, and the Public Interest. Baltimore: The Johns Hopkins Press.

Stoner, J. (1968). Risky and Cautious Shifts in Group Decisions: The Influence of Widely Held Values. Journal of Experimental Social Psychology, 442-459. Obtenido de http://www.sciencedirect.com/ science/article/pii/0022103168900693

Streb, J. M. (1998). El significado de la racionalidad en economía. Buenos Aires: Universidad del CEMA.

Superintendencia de Sociedades. (febrero de 2015). Boletín Jurídico.

Tamayo, A. (2009). La Responsabilidad Civil Extracontractual y la Contractual. Bogotá: Doctrina y Ley.

Valencia Zea, A. (1983). Derecho Civil, Tomo III, Obligaciones. Bogotá: Temis.

Velandia, M. (2011). Derecho de la competencia y del consumo . Bogotá: Universidad Externado de Colombia.

Velásquez, O. (2004). Responsabilidad civil extracontractual. Bogotá: Editorial Temis.

Zajonc, R. (16 de Julio de 1965). Social Facilitation. Science, 149(3681), 269-274. Obtenido de http://www2.psych.ubc.ca/ schaller/Psyc591Readings/Zajonc1965.pdf 



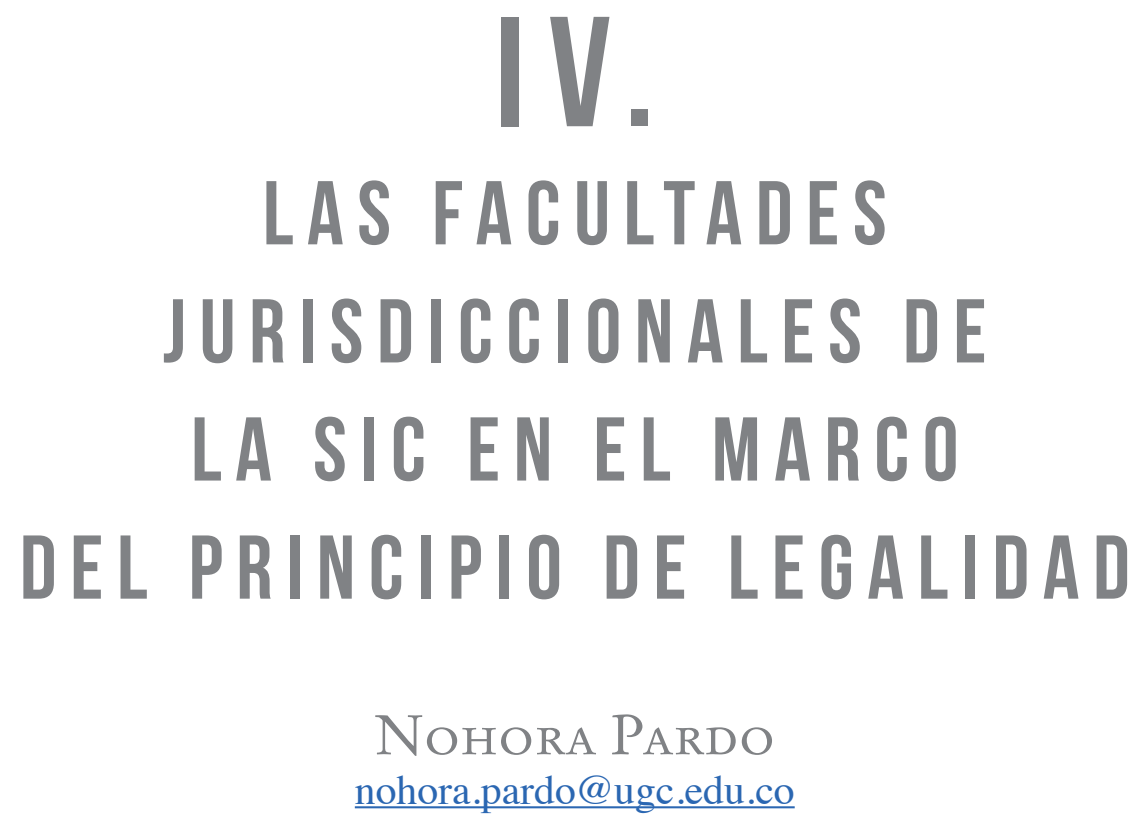



Resumen. Bajo el esquema tradicional, la administración de justicia se encuentra a cargo de la rama judicial en sus diferentes órdenes; no obstante, en la actualidad y con fundamento constitucional, la situación ha variado otorgando facultades jurisdiccionales a las autoridades administrativas, atribución de competencia del legislador de conformidad con los parámetros del artículo 116 constitucional. Las facultades jurisdiccionales que ostentan algunas entidades administrativas son de orden excepcional y se encuentran sujetas al irrestricto respeto del debido proceso y las garantías procesales. En materia de derecho del consumidor, la superintendencia de industria y comercio, entidad que tiene a su cargo el trámite eminentemente administrativo, cuenta en la actualidad con funciones de carácter jurisdiccional conferidas por la ley y reiteradas en el código general del proceso. Por consiguiente, el tema central de este capítulo se formula a partir del siguiente interrogante: ¿Cuáles fueron los aspectos de orden jurídico considerados para otorgar funciones jurisdiccionales a la superintendencia de Industria y comercio?

El capítulo se desarrolló bajo una estrategia metodológica explorativaexplicativa a partir del método cualitativo, con predominio de fuentes primarias: decisiones jurisprudenciales que abordan el tema, estableciendo las subreglas a cumplirse para una correcta atribución de funciones jurisdiccionales a autoridades administrativas.

Palabras clave. Autoridad, facultad, jurisdiccional, garantías, derechos. Superintendencia.

\section{Introducción}

En el ordenamiento jurídico colombiano se establece como norma general que las funciones jurisdiccionales son ejercidas por la rama judicial del poder público, norma que tiene su excepción, por cuanto es posible que autoridades administrativas por disposición del legislador asuman competencias jurisdic- 
cionales; es el caso de la Superintendencia de Industria y comercio, que cuenta con facultades jurisdiccionales para la defensa del consumidor.

Precisando: toda actuación judicial y/o administrativa se encuentra regida por mandato de la Carta Política de 1991 en las reglas del debido proceso; derecho que ostenta la categoría de fundamental y de aplicación inmediata (C.Const. C-827 de 2001). Por lo tanto, la protección del consumidor se somete a los procedimientos y requisitos legales y reglamentariamente establecidos. Con esto se pretende el debido reconocimiento de sus derechos como también de las garantías de protección a los mismos, bajo los medios idóneos y oportunidades de defensa necesarios, de manera que garanticen la legalidad y certeza jurídica en las resoluciones que allí se adopten.

El presente capítulo presenta avances de la investigación en materia de protección al consumidor y su régimen procesal, en relación con la función jurisdiccional de la Superintendencia de Industria y Comercio, en adelante SIC.

Si bien existe una norma legal que determina la competencia de la SIC, las actuaciones que se surtan en la instancia jurisdiccional deben enmarcarse en los postulados constitucionales que garantizan la expedición de actos administrativos respetando los derechos de los administrados.

\section{I.I. Protección de los consumidores: entre el mandato cons- titucional y la potestad de configuración del Legislador}

Al efectuar el análisis de la protección normativa del consumidor en el ámbito interno, es forzosa la revisión de la norma superior y su correspondiente desarrollo legislativo.

Las facultades otorgadas al legislador, parten del artículo 78 constitucional que le confiere la facultad de dictar las normas dirigidas a controlar la calidad de los bienes y servicios ofrecidos y prestados a la comunidad y la 
información que debe suministrarse al público en su comercialización. Adicionalmente, se consagra la responsabilidad para productores y comercializadores de bienes y servicios, cuando en desarrollo de tal actividad atentan contra la salud y la seguridad. Por último impone al Estado garantizar la participación de los consumidores en el estudio y discusión de las normas que les conciernen, previa organización representativa y democrática.

Por ser derechos que ostentan la categoría de colectivos, la protección y garantías constitucionales se enuncian en el artículo que establece las acciones populares y de grupo, dentro de los que se cuentan los derechos de los consumidores y usuarios.

Como lo afirma Villalba (2009, p. 89), del artículo 78 se derivan dos deberes de información y seguridad que tienen los productores frente a los consumidores. Principios que considera como la columna vertebral de la protección a los consumidores.

El máximo tribunal constitucional, ha proferido sentencias de acción pública de constitucionalidad, que han revisado las facultades del legislador por vicios de procedimiento o sustanciales en su actividad; ante el examen de constitucionalidad de algunos artículos del mismo Decreto Ley 3466 de 1982, anterior Estatuto del Consumidor, frente a las garantías de calidad que deben ofrecer quienes distribuyen los bienes o servicios y el procedimiento para hacer efectivas estas garantías, manifestó que las facultades de configuración procesal y sustancial para la protección del consumidor corresponden al legislador por orden expresa del constituyente. En en particular cabe resaltar:

La Constitución delimita un campo de protección, pero el contenido preciso del programa de defensa del interés tutelado, es el que se desarrolla y adiciona por la ley y por otras normas y fuentes de reglas jurídicamente válidas... En otras palabras, la deferencia de la Corte con el principio de libertad configurativa respecto de los regímenes de protección especial, se subordina al 
cumplimiento razonable del programa de defensa instituido por la propia Constitución y cuyo desarrollo se confía al órgano democrático (...).

Por consiguiente, el legislador no goza de libertad absoluta para configurar el régimen de los derechos de los consumidores. En su accionar debe sujetarse al mandato superior para una integra protección, lo que implica la revisión del proceso productivo y con ello lograr normas que blinden de la desigualdad a los consumidores en las relaciones de mercado.

En verdad, es deber del órgano legislativo tener en cuenta las relaciones desiguales que emergen de las relaciones comerciales que conllevan a observar con atención la indefensión a la que se ve sometido el consumidor y obrar conforme a su deber constitucional de regulación. (C. Cosnt. C-649 de 2001) y como lo expone (Quintero, 2014, p.98), no ha sido fácil la regulación normativa para la protección del consumidor, por cuanto desde la década pasada se habían presentados iniciativas en la materia que de manera concreta agrupa; dada su importancia se presenta de manera textual:

No ha sido fácil reglamentar los derechos de los consumidores. En 1993 fracasó la iniciativa de crear un estatuto; en 2000 otro proyecto no pasó de la Cámara, y en 2008 un tercero sucumbió en el Senado. Una vez revisados los antecedentes de la Ley 1480 se pudo verificar que en el Congreso de la República en el año 2000 ya se había presentado un proyecto de Ley destinado a actualizar el Estatuto del Consumidor con las siguientes características: 1 . Proyecto de Ley Senado n. ${ }^{\circ}$ 262, 2. Proyecto Ley Cámara n. ${ }^{\circ} 115$, 3.Título Original del Proyecto: "Por el cual se expide el Estatuto del Consumidor y del Usuario”, 4. Autor: Ministro de Desarrollo Económico: Augusto Ramírez Ocampo, 5. Ponentes Cámara: Bernabé Celis y Eduardo Benítez, y, 6. Finalmente no fue aprobado. Después, en el año 2010, se inició el proceso para llegar a la Ley 1480 de 2011 con las siguientes características: 1. 
Proyecto de Ley Senado n. ${ }^{\circ}$ 252, 2. Proyecto de Ley Cámara n. ${ }^{\circ}$ 89, 3. Título Original del Proyecto "Por medio de la cual se expide el Estatuto del Consumidor, se crea una contribución para la defensa del mismo y se dictan otras disposiciones”, 4. Autores: Representante Simón Gaviria Muñoz, Nicolás Jiménez Paternina, Senador Manuel Guillermo Mora Jaramillo, Karime Motta y Juan Manuel Galán Pachón, Bernardo Elías Vidal, Juan Manuel Corzo Román y otros, 5. Ponente Senado: Senadores Antonio Guerra de la Espriella, Juan Mario Laserna Jaramillo, 6. Ponente Cámara: Representante Simón Gaviria Muñoz (coordinador), Gerardo Tamayo Tamayo, Buenaventura León, Eduardo Enrique P, Jaime Rodríguez C. y, 6. Finalmente es aprobado el proyecto de ley a través de la Ley 1480. (p. 98)

En consecuencia, las normas que el legislador profiera, en virtud de la competencia que le ha sido otorgada para regular el régimen de protección de los derechos del consumidor, está a tono con los mandatos establecidos en la carta constitucional y son desarrollo efectivo de la misma.

\section{La asignación de funciones jurisdiccionales a la SIC}

Es la Constitución política, la encargada de establecer el régimen del Estado colombiano y determinar su organización como República unitaria descentralizada regulación contenida en el artículo primero. A su turno el artículo 116 de la Constitución consagra la posibilidad de atribuir funciones jurisdiccionales a autoridades administrativas, de ahí se deriva la legalidad de la temática que se presenta a continuación.

La asignación de funciones judiciales a la administración, requirió de una regulación especial que se llevó a cabo mediante la Ley Estatutaria 270 de 1996, en cuyo artículo 13 se trascribe casi de manera literal el mandato constitucional arriba señalado. Posteriormente La Ley 1285 de 2009 que modificó 
la Ley 270 atribuyó funciones jurisdiccionales a ciertas y determinadas autoridades administrativas, para que conozcan de asuntos que por su naturaleza o cuantía puedan ser resueltos por aquellas de manera adecuada y eficaz. Dispuso el trámite procedimental a partir del respeto por la garantía al debido proceso y así mismo, reguló que las sentencias o decisiones definitivas que en asuntos judiciales profirieran las autoridades administrativas eran susceptibles de control jurisdiccional. (C. Const. 896 de 2012)

Teniendo en cuenta que, las superintendencias pertenecen al nivel central y se encuentran reguladas en el artículo 66 de la Ley 489 de 1998 para cumplir funciones de inspección o vigilancia conforme a la ley o por delegación que efectúa el presidente, es posible otorgar funciones jurisdiccionales en los asuntos que controlan o vigilan pero esto de manera excepcional en cumplimiento de los principios rectores de la actividad administrativa en particular: celeridad y eficacia, y en estricto cumplimiento del artículo 113 de la Carta Política conforme al cual, aunque los diferentes órganos del Estado tienen funciones separadas, colaboran armónicamente para la realización de sus fines.

Por su parte, la jurisprudencia constitucional enlistó las condiciones para la atribución de funciones jurisdiccionales a las autoridades administrativas (C. Const. C-117 de 2008) en los siguientes términos:

(i) las materias específicas deben estar precisadas en la ley, (ii) no pueden tener por objeto la instrucción de sumarios o el juzgamiento de delitos y, (iii) al interior de la Superintendencia debe estar estructuralmente diferenciado el ámbito de la función judicial del correspondiente a las funciones administrativas de inspección, vigilancia y control. Por lo tanto, no pueden ser ejercidas ambas funciones por los mismos funcionarios.

El caso de atribución de funciones jurisdiccionales fue tratado en la sentencia C-212 de 1994 y reiterado en la sentencia C-1641 que afirmó: 
Así, pues, el artículo 116, como otras disposiciones constitucionales, establece por regla general que la función de administrar justicia corresponde a la Corte Constitucional, a la Corte Suprema de Justicia, al Consejo de Estado, al Consejo Superior de la Judicatura, a la Fiscalía General de la Nación, a los tribunales y a los jueces, pero establece la posibilidad de que órganos ajenos a la Rama Judicial también lo hagan: así, el Congreso ejercerá determinadas funciones judiciales -tal es el caso de las atribuidas en los artículos 174 y 178 de la Constitución- y excepcionalmente la ley podrá atribuir función jurisdiccional en materias precisas a determinadas autoridades administrativas. Aún los particulares pueden ser investidos transitoriamente de dicha función cuando actúen como conciliadores o árbitros habilitados por las partes para proferir fallos en derecho o en equidad, en los términos que determine la ley.

Como se ha dicho, las facultades jurisdiccionales en cabeza de órganos de la administración son excepcionales, carácter que es reiterado en las sentencias C-415 de 2002, T-302 de 2011 en las que además se hace expresa consideración de que la asignación "debe ser precisa, de modo que la materia sobre la cual recaiga sea puntual, exacta, que no pueda extenderse ni confundirse”.

Por otro lado, las funciones jurisdiccionales de las autoridades administrativas requieren de independencia e imparcialidad, así se señaló en la sentencia C-1641 de 2000 que analiza el artículo 116 a la luz de las normas internacionales de derechos humanos, la Convención Interamericana y el Pacto de Derechos Civiles y Políticos, concluyendo que en respeto de las normas antes mencionadas el funcionario deberá actuar con imparcialidad e independencia propias del actuar en la jurisdicción.

La imparcialidad en el ejercicio de funciones jurisdiccionales por parte de autoridades administrativas, fue revisada para la SIC frente a sus funciones de vigilancia y control de la competencia desleal; en esa oportunidad se seña- 
ló, mediante fallo modulado y en procura de esta garantía, que no es posible que un funcionario o despacho de la Superintendencia de Industria y Comercio, ejerza funciones jurisdiccionales en el tema de competencia desleal, cuando ha conocido con anterioridad dicho caso en uso de sus funciones administrativas de inspección, vigilancia y control ( C.Const. C-649 de 2001).

Para el caso de las funciones jurisdiccionales en materia de protección al consumidor el tribunal constitucional partió de tres hipótesis con trato diferencial: la primera, cuando la función jurisdiccional se ejerce bajo imparcialidad e independencia, caso de la sentencia C-1143 de 2000 que declaró la constitucionalidad de la posibilidad de que la Superintendencia de Sociedades pudiera incoar la acción revocatoria concursal. La segunda, que no es posible distinguir la función de control y vigilancia de la jurisdiccional expuesto en la sentencia C-1641 de 2000, en relación con ciertas funciones judiciales de la Superintendencia Bancaria. Por último, cuando se presentan interferencias entre las funciones judiciales y las labores de vigilancia y control, lo que implica que la entidad ajuste su estructura y funcionamiento para proteger la imparcialidad de la función judicial. Para este caso ver sentencia C-649 de 2001 en relación con las atribuciones judiciales de la Superintendencia de Industria y Comercio en materia de competencia desleal. Esta última posición fue reiterada para las funciones de la SIC en protección al consumidor.

\section{I. Reglas constitucionales relativas a la atribución de fun- ciones judiciales a las autoridades administrativas}

Ante la carencia de un texto normativo que establezca de forma clara las reglas para atribuir funciones jurisdiccionales a autoridades administrativas, se han señalado por parte de la jurisprudencia de la Corte Constitucional, los parámetros a seguir en estos eventos (C-896/12, C-156/13).

La primera regla que se denominará habilitación legislativa, en el acceso a la administración de justicia, fundada en el artículo 116 constitucional 
y en la colaboración armónica en el marco del debido proceso. (Sentencia C-156 de 2013.). Se desprende de esta primera regla la obligación de consagrar en el texto legal tales competencias para con ello salvaguardar imparcialidad e independencia y el principio de eficiencia en materia de administración de justicia.

La segunda regla: reserva legal de los contenidos mínimos de la legislación. Muy afín con la primera por cuanto impone al legislador precisar el órgano encargado de ejercer la función jurisdiccional y la materia sobre la que se ejercerá tal función para proteger la garantía del juez natural.

En tercer lugar, se presenta atribución excepcional de funciones jurisdiccionales a las autoridades administrativas, que encuentra su sustento a nivel constitucional sin que esto deba confundirse con transitorio y nuevamente, como fue expuesto en la regla anterior, será necesaria una asignación específica porque la asignación genérica, incierta e indeterminada se interpreta contraria al artículo 116. (C. Const.- 156 de 2013). También se contraría esta regla cuando la autoridad no cumple su actividad administrativa por hacerse cargo de las funciones jurisdiccionales.

Por tanto, hay subreglas en derecho que deben tenerse en cuenta al momento de atribuir facultades jurisdiccionales a autoridades administrativas, lo que limita el poder del legislador y a su vez de la autoridad, preservando el debido proceso y las demás garantías procesales.

\subsection{Doctrina probable de la SIC. Razones para adoptar el precedente}

Señala (Zagrebelsky, 2011, P 102), que el concepto de Estado Social de Derecho tiene dos caracterizaciones: la primera desde el punto de vista económico, que consiste en la constitucionalización de derechos de propiedad y libre iniciativa, y en segundo lugar, la valoración en el Estado de exigencias, de justi- 
cia para dos órdenes: el individual y el general. Es decir, bajo esas atribuciones el Estado protege y garantiza a los asociados mediante la toma de decisiones fundadas en la constitución y la ley. Para el derecho del consumidor las atribuciones del Estado se plasman en regulaciones generales, verbigracia la doctrina probable de la SIC.

Los múltiples conflictos que se presentan en la sociedad y las decisiones sobre los mismos, imponen a las autoridades la obligación de garantizar la efectividad de los derechos y deberes (C.P. artículo $2^{\circ}$ ), a través del derecho, como sistema estable de ordenación social, que implica la adopción de decisiones iguales en casos similares, lo que se denomina precedente y es la base fundante de la doctrina probable en el orden jurídico colombiano.

Por consiguiente, la certeza comporta la debida sujeción a la seguridad jurídica relacionada con la buena fe, consagrada en el artículo 83 de la Constitución, a partir del principio de la confianza legítima. Este principio constitucional garantiza a las personas que ni el Estado, ni los particulares, van a actuar sin consideración del marco jurídico y por tanto las decisiones de uno y otros se pueden prever a partir de circunstancias similares, hecho que genera seguridad y coherencia para los asociados.

Al respecto ha considerado la Corte Constitucional que:

(...) el análisis de la actividad del Estado como administrador de justicia no se agota en el juicio sobre la legalidad de cada decisión tomada como un acto jurídico individual, pues no se trata de hacer un estudio sobre la validez de la sentencia, sino de la razonabilidad de una conducta estatal, entendida esta en términos más amplios, a partir de los principios de continuidad y de unidad de la jurisdicción. (C. Cosnt. 836 de 2001)

Si bien es cierto, la adopción del precedente se funda en la propia constitución, esto va más allá del texto constitucional y otorga la garantía de cer- 
teza, seguridad y buena fe a los administrados sin consideración de su individualidad. La doctrina probable en el régimen colombiano no es reciente, su uso por el máximo tribunal de la jurisdicción ordinaria ha obedecido al cumplimiento de la normatividad y se define como la técnica de vinculación al precedente después de presentarse tres decisiones constantes sobre el mismo punto.

Sus antecedentes fueron expuestos en la Sentencia C-836 de 2001. que establece su origen en la doctrina legal más probable, consagrada en el artículo 10 de la Ley 153 de 1887. Posteriormente en la Ley 105 de 1890 la obligatoriedad para los jueces de seguir la interpretación hecha por la Corte Suprema cambió el nombre de doctrina legal más probable a doctrina legal. Finalmente en el artículo $4^{\circ}$ de la Ley 169 de 1896 estableció el artículo vigente de la doctrina probable para la Corte Suprema de Justicia.

Ahora bien, la relación de la doctrina probable y los actos administrativos que contienen las decisiones de la SIC, parten de la Ley 1340 de 2009, que expuso el legislador como motivos lo preceptuado en el artículo 333 que trata de la actividad económica y la iniciativa privada e impone el deber al Estado de evitar su restricción; con fundamento en ello y en la seguridad jurídica que debe acompañar a los ciudadanos, se motivó la doctrina probable de la SIC (Senado de la República, Proyecto de Ley número 195 de 2007, Gaceta del Congreso, Año XVI, No 583, Bogotá, 16 de noviembre de 2007).

El proyecto de ley que dio lugar a la aprobación de la Ley 1340 de 2009, tenía como propósito otorgar competencias a la Superintendencia de Industria y Comercio para que conozca de forma privativa de las prácticas comerciales restrictivas, y establecer en Colombia una entidad única y especializada que conozca de los asuntos sobre la libre competencia.

Por consiguiente, en la Ley 1340 el 24 de julio de 2009 se concreta esta aspiración y en el artículo $6^{\circ}$ titulado "Autoridad Nacional de protección de la competencia” se consagra que: 
La Superintendencia de Industria y Comercio conocerá en forma privativa de las investigaciones administrativas, impondrá las multas y adoptará las demás decisiones administrativas por infracción a las disposiciones sobre protección de la competencia, así como en relación con la vigilancia administrativa del cumplimiento de las disposiciones sobre competencia desleal.

Abordando el tema de doctrina probable, la jurisprudencia parte de la similitud entre la Superintendencia Financiera y la SIC. El proyecto de ley consideró: "como actualmente se hace en la Superintendencia Financiera con mucho éxito y se consagra como una causal eximente [sic] de responsabilidad, haber actuado de conformidad con la doctrina publicada por la autoridad de supervisión” (p. 21). Proyecto de Ley Número 195 de 2007, Ponencia para Primer Debate al proyecto de Ley Número 195 de 2007, Senado, Gaceta del Congreso, No 169, Bogotá, 23 de abril de 2008.

En cumplimiento de las funciones administrativas la SIC ordena la apertura de investigaciones, impone sanciones mediante multas ${ }^{1}$, aprueba u objeta integraciones empresariales, otorga beneficios por colaboración con la autoridad ${ }^{2}$, situaciones que se materializan en actos administrativos.

\footnotetext{
1. El artículo 25 de la Ley amplió las multas por violación al régimen de libre competencia de dos mil (2.000) salarios mínimos legales vigentes (SMLV) a cien mil (100.000) SMLV. Este artículo reformó el numeral 15 del artículo 4 del Decreto 2153 de 1992. La Sentencia C-228 de 2010 (M.P. Luis Ernesto Vargas Silva), estableció que estas multas las puede establecer la SIC en ejercicio del derecho administrativo sancionador.

2. El artículo 14 de la Ley 1340 establece, "BENEFICIOS POR COLABORACIÓN CON LA AUTORIDAD. La Superintendencia de Industria y Comercio podrá conceder beneficios a las personas naturales o jurídicas que hubieren participado en una conducta que viole las normas de protección a la competencia, en caso de que informen a la autoridad de competencia acerca de la existencia de dicha conducta y/o colaboren con la entrega de información y pruebas, incluida la identificación de los demás participantes, aun cuando la autoridad de competencia ya se encuentre adelantando la correspondiente actuación. Lo anterior, de conformidad con las siguientes reglas: 1. Los beneficios podrán incluir la exoneración total o parcial de la multa que le sería impuesta. No podrán acceder a los beneficios el instigador o promotor de la conducta. 2. La Superintendencia de Industria y Comercio establecerá si hay lugar a la obtención de beneficios y los determinará en función de la calidad y utilidad de la información que se suministre, teniendo en cuenta los siguientes factores: a) La eficacia de la colaboración en el esclarecimiento de los hechos y en la represión de las conductas, entendiéndose por colaboración con las autoridades el suministro de información y de pruebas que permitan establecer la existencia, modalidad, duración y efectos de la conducta, así como la identidad de los responsables, su grado de participación y el beneficio obtenido con la conducta ilegal, b) La oportunidad en que las autoridades reciban la colaboración”.
} 
En definitiva, la doctrina probable que establece la Ley 1340 de 2009 en su artículo 24, aplica únicamente para la competencia administrativa de la SIC en materia de protección de la libre competencia ${ }^{3}$ Consideró la Corte que no existe prohibición constitucional para que a través de la ley se pueda establecer la figura de la doctrina probable de carácter administrativo. No obstante esta doctrina no tiene carácter de inmutable, podrá variar siempre y cuando motive el acto administrativo con razones suficientes para evitar la vulneración de los principios de igualdad, seguridad jurídica, buena fe y confianza legítima, propios del Estado Social de Derecho.

\subsection{Competencias jurisdiccionales que cumple la SIC. En materia de protección al consumidor.}

En la protección al consumidor, la SIC tiene facultades administrativas y jurisdiccionales. Este hecho puede dar lugar a que se presenten problemas de interpretación y se confundan los aspectos sustanciales y procesales de cada una de las áreas. Con relación al marco normativo que tiene la SIC, en materia de protección al consumidor, se destaca la Ley 1480 Estatuto de Protección al Consumidor, y el artículo 145 de la Ley 446 de 1998, específicamente en materia de atribuciones jurisdiccionales.

El artículo 145 de la Ley 446 de 1998 establece que La Superintendencia de Industria y Comercio ejercerá, a prevención, para la protección al consumidor las siguientes funciones: por información engañosa podrá ordenar el cese y difusión correctiva, la efectividad de las garantías de bienes y servicios, la suspensión inmediata y de manera preventiva de la producción, la comercialización de bienes y/o el servicio por un término de treinta (30) días, y por último, llevar a cabo las investigaciones a los proveedores u organizaciones de consumidores por violación de cualquiera de las disposiciones legales sobre

\footnotetext{
3. A excepción de la autorización previa de acuerdos y convenios en el sector agrícola en donde dará concepto previo el Ministerio de Agricultura y Desarrollo Rural, según el art. 5 de la Ley 1340. Igualmente la Superintendencia Financiera conocerá de las integraciones empresariales en donde participen exclusivamente empresas vigiladas por esta entidad (numeral $2^{\circ}$ del artículo $9^{\circ}$ de la Ley 1340 ).
} 
protección del consumidor, e imponer las sanciones que corresponda. El estudio constitucional efectuado en la Sentencia C-1071 de 2002 fue claro al afirmar que dichas funciones son jurisdiccionales porque en el encabezado del artículo se establece que la Superintendencia de Industria y Comercio “ejercerá a prevención” dichas atribuciones. Por lo tanto, el consumidor podrá acudir a la jurisdicción ordinaria o ante la SIC en el ejercicio de funciones jurisdiccionales.

Las funciones jurisdiccionales se realizan conforme al numeral $2^{\circ} \mathrm{del}$ artículo 14 del Decreto 3523 de 2009 que establece que al Superintendente delegado para asuntos jurisdiccionales le corresponde, "Adelantar de acuerdo con el procedimiento legalmente aplicable, en única o primera instancia según corresponda de acuerdo con la cuantía, el trámite de los procesos que deban iniciarse en ejercicio de las funciones jurisdiccionales de protección al consumidor”.

A su vez el artículo 24 de la Ley 1562 de 2012, código general del proceso lista los eventos de jurisdicción en seis numerales; para el caso en estudio solo es pertinente el numeral 1 que señala las funciones de la SIC por violación a los derechos de los consumidores establecidos en el Estatuto del Consumidor y de las normas relativas a la competencia desleal.

En observancia del principio de legalidad, se establece el procedimiento para acudir a la SIC en uso de sus facultades jurisdiccionales en procura de la protección de los derechos del consumidor: 


\section{Capítulo IV}

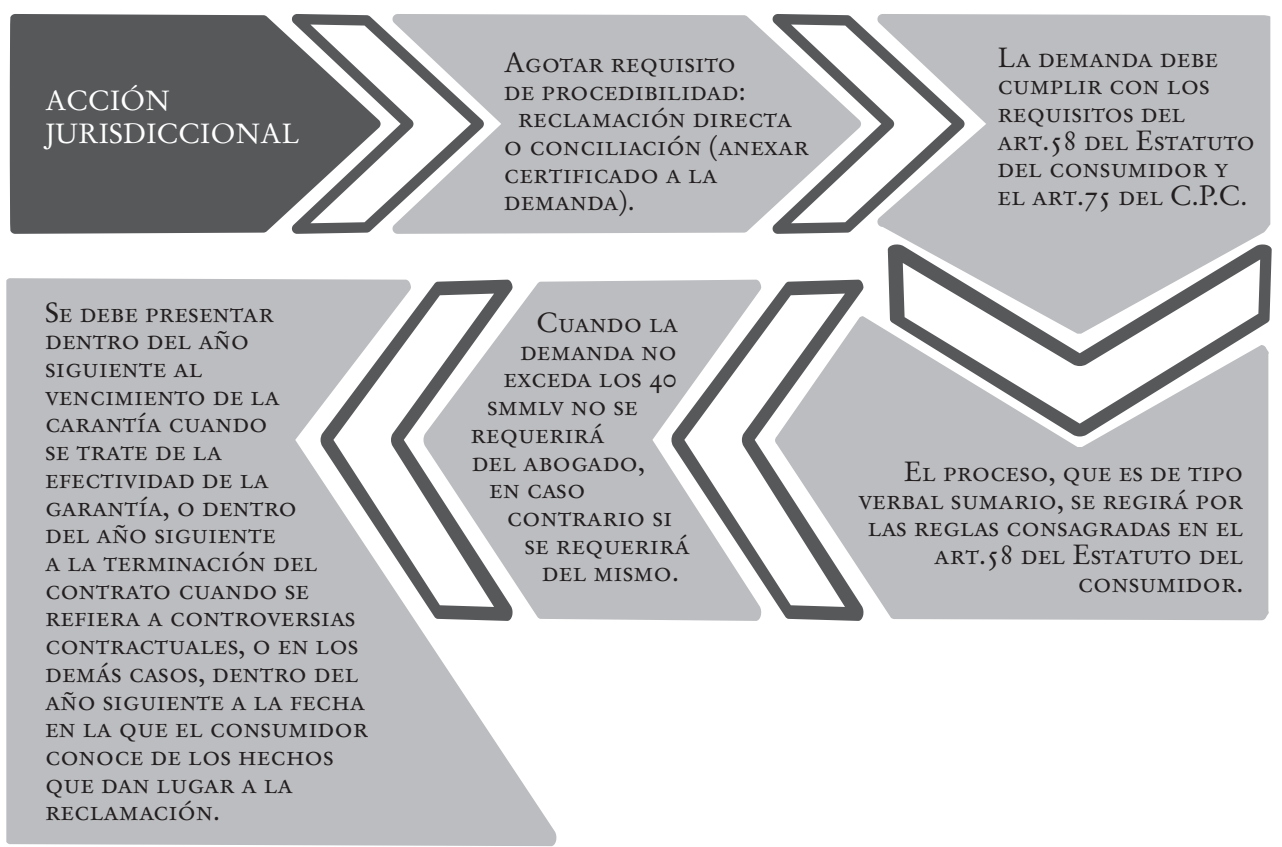

Cuadro 1. Procedimiento para acudir a la Sic Elaboración Auxiliares de Investigación

De conformidad con el artículo 148 de la Ley 446 de 1998 en el cumplimiento de las funciones jurisdiccionales en este campo, le corresponderá a la Superintendencia aplicar el procedimiento verbal sumario previsto en el artículo 390 del CGP que en su parágrafo 3 señala: "Los procesos que versen sobre violación a los derechos de los consumidores establecidos en normas generales o especiales, con excepción de las acciones populares y de grupo, se tramitarán por el proceso verbal o por el verbal sumario, según la cuantía,” sin consideración de la autoridad competente. De acuerdo a la organización de la SIC, estas funciones son asumidas por la Delegatura para asuntos jurisdiccionales y tiene como objeto la reparación de los daños causados a los bienes en la prestación de servicios o por información o publicidad engañosa, independientemente del sector de la economía en que se hayan vulnerado los derechos. 
Por otra parte, el uso temerario de la acción jurisdiccional, implica la configuración de la mala fe prevista en el artículo 58 de la Ley 1480/11, con la consecuencia de la imposición de la sanción económica que puede ser hasta de 150 salarios mínimos mensuales legales vigentes, la cual se impone en sentencia que desestima las pretensiones proferidas dentro del proceso de protección al consumidor (SIC Concepto 16084133, 13/05/2016).

Los actos administrativos proferidos por la SIC en sede jurisdiccional, son susceptibles de control ante el juez de lo contencioso administrativo quien ha encontrado ajustado a derecho actos sancionatorios previo el control de legalidad, verbigracia, la pretensión de nulidad incoada por varias de las estaciones de servicio de combustible ubicadas en el municipio de Duitama (Boyacá) con ocasión de los acuerdos para la fijación de precios iguales o idénticos para un mismo producto en un mismo tiempo y valor, con incrementos o variaciones en los mismos periodos de tiempo y en igual proporción, situación que llevo al Consejo de Estado a considerar que hubo un acuerdo que tuvo por efecto la fijación indirecta de precios del producto, constitutivo de prácticas y procedimientos tendientes a limitar la libre competencia. (Consejo de Estado Sección Primera, Sentencia 15001233300020130025401, 13/11/2014).

En similar sentido, el Consejo de Estado confirmó la sanción impuesta a un operador de telefonía móvil que omitió atender 49 requerimientos hechos por esa entidad frente a las quejas y reclamos de los usuarios. Expuso el juzgador que se omitió rendir explicaciones sobre su injusta demora en la resolución de las peticiones, fundamento que también fue expuesto por la SIC en la parte motiva del acto de sanción. (Consejo de Estado Sección Primera, Sentencia 250002324000200600321, 06/11/2014).

Para Gases de Occidente S.A. ESP, la situación no varió en la jurisdicción contenciosa administrativa. Se exponen como motivos en el acto particular que se establecieron requisitos restrictivos de la competencia, para otorgar el registro de instaladores de redes internas de gas natural, en el período 
de abril a agosto de 2011, lo que llevó a que instaladores independientes no pudieran acceder al registro, ni estuvieran autorizados para ofrecer sus servicios a los usuarios del mercado de distribución de gas. Con estas conductas se constató el comportamiento abusivo de una posición de dominio, conforme lo establece el numeral 6 del artículo 50 del Decreto 2153 de 1992 y, por consiguiente, violatoria del artículo 34 de la Ley 142 de 1994. Concluye el Consejo de Estado que no se desconoció el debido proceso ni se incurrió en falsa motivación al imponer sanción a Gases de Occidente S.A. ESP. (Consejo de Estado, 2076400 25000-23-41-000-2013-02773-01. 30/07/2015).

\subsection{Garantías constitucionales en la acción jurisdiccional}

El debido proceso, establecido en el artículo 29 de la Constitución Política presenta una doble connotación: garantías y derecho fundamental, que a su vez gira en tres presupuestos (i) el derecho de defensa y contradicción, (ii) el impulso y trámite de los procesos conforme con las formas establecidas para cada juicio o procedimiento y (iii) que el asunto sea resuelto por el juez o funcionario competente. Este artículo contiene las bases de todo procedimiento u actuación administrativa, constituyéndose en la herramienta para la debida protección de los derechos de los administrados. (C. Const. C-980 de 2010.).

Se garantizan el derecho de defensa y de contradicción mediante los medios de prueba y las oportunidades para controvertir las afirmaciones expuestas en los hechos, unido al material probatorio, el impulso y trámite de los procesos se ciñe a las formas establecidas para cada juicio o procedimiento administrativo, situación que es vulnerada por las autoridades públicas, en ejercicio de función administrativa por crear o aplicar procedimientos no establecidos en la normatividad lo que implica el desconocimiento de las garantías reconocidas a los administrados. Y el tercer presupuesto tiene que ver con la competencia de la autoridad o funcionario para tramitar la actuación. 
Ahora bien, el debido proceso no es una condición sine qua non de los procedimientos judiciales, se extiende en su aplicación a todas las actuaciones administrativas, con ello se garantizan actos administrativos que respeten el principio de legalidad. La Corte Constitucional, en la Sentencia C-341 de 2014 consideró:

(...) en el marco de las actuaciones que se adelantan ante la administración, el debido proceso se relaciona directamente con el comportamiento que deben observar todas las autoridades públicas en el ejercicio de sus funciones, en cuanto se encuentran obligadas a actuar conforme a los procedimientos previamente definidos por la ley para la creación, modificación o extinción de determinadas situaciones jurídicas de los administrados, como una manera de garantizar los derechos que puedan resultar involucrados por sus decisiones.

En concordancia con lo anterior, se han presentado por el tribunal constitucional una lista de garantías del debido proceso administrativo, a saber: (a) el derecho a conocer el inicio de la actuación, (b) a ser oído durante todo el trámite, (c) a ser notificado en debida forma, (d) a que se adelante por autoridad competente y con pleno respeto de las formas propias de cada juicio, (e) a que no se presenten dilaciones injustificadas, (f) a gozar de la presunción de inocencia, (g) a ejercer los derechos de defensa y contradicción, (h) a presentar pruebas y a controvertir aquellas que aporte la parte contraria, (i) a que se resuelva en forma motivada la situación planteada, (j) a impugnar la decisión que se adopte y a promover la nulidad de los actos que se expidan con vulneración del debido proceso ( C.Cons T-957 de 2011).

La noción de debido proceso ha sido ampliamente debatida por la Corte Constitucional y sobre ello ha considerado:

En esencia, el derecho al debido proceso tiene la función de defender y preservar el valor de la justicia reconocida en el preám- 
bulo de la Carta Fundamental, como una garantía de la convivencia social de los integrantes de la comunidad nacional.

La autoridad que conoce y resuelve sobre la situación jurídica sometida a su decisión. En tal virtud, y como garantía de respeto a dichos principios, el proceso se institucionaliza y normatiza, mediante estatutos escritos que contienen mandatos reguladores de la conducta de las autoridades administrativas o judiciales, encaminados a asegurar el ejercicio regular de sus competencias. (C. Const. Sentencia C-214/94)

No obstante, por el amplio poder de configuración legislativa que implica la caracterización de cada procedimiento y proceso, el legislador deberá tener en cuenta las garantías básicas previstas por el Constituyente, por cuanto ellas se constituyen en el punto de referencia indispensable para saber si en la práctica, en cada asunto particular, ha sido acatada la garantía fundamental del artículo 29 (C. Const. C- 095/01).

A su vez, el derecho al debido proceso, no es un derecho absoluto y en consecuencia puede ser objeto de limitaciones siempre que estas se funden en la necesidad de alcanzar otros principios superiores o para garantizar otros derechos fundamentales cuando pueda presentarse colisión o conflicto (C. Cosnt. C-648/01 M.P. Marco Gerardo Monroy Cabra).

Sobre el particular se afirma:

En síntesis, como la concepción «absolutista» de los derechos en conflicto puede conducir a resultados lógica y conceptualmente inaceptables, la Carta opta por preferir que los derechos sean garantizados en la mayor medida posible, para lo cual deben sujetarse a restricciones adecuadas, necesarias y proporcionales que aseguren su coexistencia armónica (C .Cosnt. C- 475/97). 
La mención al debido proceso parte de su carácter de derecho fundamental y a su vez de ser necesario a la hora de concreción de principios y garantías de igual rango constitucional, verbigracia el principio de legalidad, el derecho de igualdad y el derecho al acceso a la administración de justicia propia de estados constitucionales y democráticos (C.Const. T-416/98).

A su turno, la salvaguarda del debido proceso para el investigado se lleva a cabo cuando este órgano administrativo establece claramente y sin lugar a equívocos la naturaleza de la función que se está ejerciendo, administrativa o jurisdiccional, para que de esa manera se pueda ejercer de manera eficaz el ejercicio del derecho de defensa (C. Const. C-649/01).

De lo expuesto, se colige que en el Estado Social de Derecho es deber de todas las autoridades, el respeto irrestricto por el debido proceso para la eficaz protección de los derechos y de los procedimientos adelantados por la administración.

El debido proceso hace parte fundamental del principio de legalidad, su acatamiento garantiza que en los órganos administrativos se ejecute conforme a lo establecido en el texto constitucional, como bien lo afirma Parejo (1990) que al dividir las competencias se materializa la división de poderes (p.51), y esto se ve representado en las actuaciones jurisdiccionales de la SIC que conforme a la jurisprudencia arriba citada, ha respetado el debido proceso y por ende la legalidad del Estado Social de Derecho Colombiano. 


\section{Conclusiones}

La atribución de funciones jurisdiccionales a la Superintendencia de Industria y Comercio, efectuada con fundamento en el artículo 116 constitucional evidencia la colaboración armónica que se pregona en la carta fundamental.

Si bien es cierto, la actividad de la SIC es el ejercicio de facultades administrativas, el legislador decidió investirla excepcionalmente de funciones jurisdiccionales para efectos de dar una mayor agilidad a ese tipo de procesos, en concordancia con los principios de la actuación administrativa artículo 209 superior y del procedimiento administrativo señalados en la Ley 1437 de 2011. Por tanto, la función jurisdiccional se enmarca en el respeto al debido proceso y las garantáis procesales.

Es relevante la extensión del concepto de doctrina probable propio de la jurisdicción ordinaria, cuya génesis data de la Ley 169 de 1896 y propugna por una unificación jurisprudencial a partir de principios de igualdad y seguridad jurídica, que en temas de protección al consumidor se consagra en el artículo 24 de la Ley 1340 de 2009.

La revisión cualitativa arrojó como resultado la correspondencia entre los motivos expuestos en los actos administrativos sancionatorios y las consideraciones del Consejo de Estado, lo que lleva a afirmar que la SIC está actuando en el marco de legalidad y respetando los derechos y garantías establecidas en el texto constitucional.

Por último, cabe recordar que las garantías consagradas en la constitución son perentorias en el actuar de la SIC, tanto en su función jurisdiccional como administrativa, porque en su condición de ente rector para la protección del consumidor está sujeta al respeto irrestricto de normas de orden constitucional y legal que otorgan a los administrados, en cualquiera de los extremos de la relación procedimental o procesal donde se encuentren, la seguridad de una decisión fundada en el respeto de las garantías y derechos. 


\section{Referencias}

C-214 de 1994

C-212 de 1994

C-475 de 1997

C-095 de 2001

C-827 de 2001

C-836 de 2001

C-649 de 2001

C-648 de 2001

C-980 de 2010

C-896 de 2012

C-156 de 2013

C-341 de 2014

Constitución Política de Colombia (1991)

Consejo de Estado www.consejodeestado.gov.co

Corte Constitucional www.corteconstitucional.gov.co

García, O. Q. (2014). Defensas administrativas y judiciales del consumidor. del decreto 3466 de 1982 a la Ley 1480 de 2011.Revista e-Mercatoria,13

(1) Recuperado de

http://search.proquest.com/docview/1744635991 ?accountid=49777

Ley 169 (1896). Sobre reformas judiciales. Diario Oficial 10235 de enero 14 de 1897

Ley 1285 (2009). Por medio de la cual se reforma la Ley 270 de 1996 Estatutaria de la Administración de Justicia. Diario Oficial 47240 de enero 22 de 2009

Ley 1340 (2009). Por medio de la cual se dictan normas en materia de protección de la competencia. Diario Oficial 47420 de julio 24 de 2009 
Ley 1437 (2011). Por la cual se expide el Código de Procedimiento Administrativo y de lo Contencioso Administrativo. Diario Oficial 47.956 de enero 18 de 2011

Ley 1480 (2011). Por medio de la cual se expide el Estatuto del Consumidor y se dictan otras disposiciones. Diario Oficial 48220 de octubre 12 de 2011.

Ley 1564 (2012). Por medio de la cual se expide el Código General del Proceso y se dictan otras disposiciones. Diario Oficial 48489 de julio 12 de 2012

Parejo, L. (1990). Manual de Derecho Administrativo. Ariel: Barcelona. Quintero García. O (2014) Defensas administrativas y judiciales del consumidor. Decreto 3466 de 1982 a la ley 1480 de 2010, p 91-125 http://revistas.uexternado.edu.co/index.php/emerca/article/ viewFile/4045/4715

S. $250002324000200600321,06 / 11 / 2014$.

S. $15001233300020130025401,13 / 11 / 2014$.

S. 25000234100020130277301, 30/07/2015.

Superintendencia de Industria y Comercio Concepto 16084133, 13/05/2016. T-416 de 1998

T-583 de 2003

T-957 de 2011

Villalba, J. C. (2009). Aspectos introductorios al derecho del consumo. Prolegómenos Derechos y Valores, XII (24),xx-xx.- ISSN 0121-182X, p 35-103

Zagrebelsky, G. (2011). El derecho dúctil. Madrid: Trotta. 



\section{V. \\ LOS CARTELES \\ DE EXPORTACIÓN Y SUS EFECTOS \\ Paola Andrea Zuluaga Ortiz pazuluag@poligran.edu.co}



Resumen. Este artículo tiene por objeto presentar los efectos de los carteles en un mercado de libre competencia, centrándose en el caso de los carteles de exportación. Así mismo, su finalidad es establecer, las problemáticas referentes a la legislación aplicable en el marco de los Tratados de Libre Comercio a estas prácticas restrictivas del comercio. El método de investigación desarrollado fue el descriptivo jurídico consistente en analizar y caracterizar un fenómeno o situación concreta indicando sus rasgos peculiares o diferenciadores y descomponerla, así como propositivo, es decir, presentar los inconvenientes presentes en las normas y aportar soluciones. Los resultados de la investigación permiten conocer los perjuicios que causan los carteles de exportación dentro del mercado internacional, así mismo, la dificultad en su persecución debido a la falta de regulación de los mismos dentro de los Acuerdos Comerciales, y a la aplicación territorial de la normativa interna de los países.

\section{Introducción}

Abordar el tema de la globalización ${ }^{1}$ de la economía, implica considerarlo como un fenómeno que entraña múltiples procesos, características e interpretaciones, los cuales desbordan los escenarios exclusivamente económicos. Para el autor Levy Dabbah (2003), la globalización -vista desde esta perspectivaconsiste en "el proceso por el cual dos o más estados deciden estrechar sus relaciones económicas, creando mecanismos para la integración gradual de sus economías, proceso que no puede ser entendido sin la uniformidad que debieran alcanzar sus sistemas jurídicos respectivos” (p. 27).

Esta definición entregada por Levy resulta de mucha utilidad, en tanto destaca dos aspectos, el primero de ellos central para el desarrollo del presen-

\footnotetext{
1. La globalización puede ser entendida como la reducción espacial del mundo o la creación de un único espacio global; de otra parte, la globalización supone interrelación de economías, mercados, finanzas, culturas, bienes y personas; además, se constata que el concepto se ha convertido en un clave explicativa de nuestro tiempo; por otro lado, se trata de una categoría poliédrica y multidimensional que describe distintos procesos; y por último, presupone el surgimiento de un nuevo orden de carácter irreversible e impredecible. Ramírez, G. (2007). Transformaciones del constitucionalismo en el contexto de la globalización. El derecho en el contexto de la globalización. Universidad Externado de Colombia. pp. 189-218.
} 
te artículo: la apertura e integración económica como supuestos de la globalización; y el otro, el papel del derecho y de los diferentes ordenamientos jurídicos en este proceso.

En el marco de esta apertura económica, cuando el intercambio de bienes, servicios y factores (Bouzas, 2008, p. 2) da lugar al comercio internacional y al replanteamiento de las relaciones comerciales, surgen los Tratados de Libre Comercio. Estos son una alternativa normativa mediante la cual dos o más países realizan acuerdos para reducir y eliminar barreras arancelarias y no arancelarias, y propiciar el crecimiento económico, político y social. Así las cosas, constituye una herramienta fundamental en el proceso de propiciar la libre competencia entre estados y participantes del mercado.

Frente a esta libre competencia, la Organización Mundial del Comercio (OMC) ha sostenido que "la competencia es un incentivo potencial para que las empresas participen con mayor ímpetu del mercado internacional, y al mismo tiempo proporcionen mayores beneficios a los consumidores y otros competidores" (Conferencia de la Organización de las Naciones Unidas, 1996, p. 2). De manera que, en un mercado ideal deben concurrir libremente los competidores, para que sean directamente los consumidores quienes decidan su permanencia o preferencia sin injerencias ni barreras innecesarias impuestas por terceros (Congreso de Derecho Comercial, 2013, p. 17).

De acuerdo con la Organización de las Naciones Unidas (ONU), este objetivo se puede alcanzar "en la medida que se ofrezcan bienes y servicios innovadores, en mayores variedades y sobre todo manejando buenos estándares de calidad a bajos precios" (1996, p. 2).

Sin embargo, es necesario considerar que algunos de los efectos más negativos de la apertura y el intercambio comercial suceden precisamente en relación con la libertad de competencia, pues a pesar de los esfuerzos por parte de las diferentes autoridades en la materia, para velar por la libre competencia entre los sujetos que concurren en el mercado, continúan presentándo- 
se prácticas que distorsionan la competencia, desplazan a los competidores y producen impactos negativos en las actividades comerciales.

Resulta importante subrayar dentro de esas prácticas a los acuerdos restrictivos de la competencia, por cuyo intermedio las empresas acuerdan la no competencia entre ellas (Congreso de Derecho Comercial, 2013, p.17), para obtener un provecho particular afectando de esta manera el interés público, es decir, el orden económico. Claramente, estas circunstancias plantean para los diferentes gobiernos y organizaciones internacionales, no solo una dificultad, sino además un enorme desafío.

Con fundamento en los planteamientos expuestos hasta el momento, el presente artículo tiene como finalidad explicar los efectos de los carteles dentro de un mercado caracterizado por la libre competencia, haciendo referencia directa a las estrategias de contención aplicables a las prácticas comerciales restrictivas, específicamente a los carteles de exportación, enmarcándolas dentro de los Acuerdos de Promoción Comerciales, más conocidos como Tratados de Libre Comercio.

\section{Efectos de los carteles dentro de un mercado de libre competencia}

\section{I. Los carteles como práctica restrictiva de la competencia}

A propósito de la definición de las prácticas restrictivas de la competencia, Rubio Escobar (2007) señala que son "todos aquellos comportamientos que tengan la capacidad o el efecto de inhibir o disminuir artificialmente las fuentes de competencia en un mercado y de eliminar sus beneficios” (p. 31). 
Es necesario indicar que las prácticas horizontales ${ }^{2}$ son aquellas que buscan restringir el comercio y que se presentan como acuerdos o pactos que tienen por objeto fijar precios, repartir un mercado, asignar cuotas de producción o distribución, y se las conoce como carteles. Estos acuerdos son celebrados entre empresas que "actúan en un mismo mercado relevante ${ }^{3}$, persiguiendo la neutralización de la competencia existente entre sus partícipes y por tanto maximizar los beneficios conjuntos, para eliminar o disminuir la competencia en un sector” (Barón, 2010, p. 76).

Así mismo, para la Organización para la Cooperación y el Desarrollo Económico OCDE los carteles constituyen un acuerdo anticompetitivo, una práctica concertada anticompetitiva o un arreglo anticompetitivo establecido por competidores para fijar los precios, manipular las licitaciones, establecer limitaciones o contingentes de producción o repartirse los mercados asignando clientes, proveedores, territorios o ramos comerciales (Sexta Conferencia de las Naciones Unidas Encargada de Examinar Todos los Aspectos en Conjunto de Principios y Normas Equitativos Convenidos Multilateralmente para el Control de las Prácticas Restrictivas, 2010, p.3). Es decir, los carteles “son pactos que restringen o limitan la competencia, surtidos entre empresas o sectores económicos, con el fin de apoderarse del mercado global, impidiendo el ingreso de nuevos competidores" (Koch, 1945, p. 131).

\footnotetext{
2. Las prácticas horizontales son aquellas que monopolizan cadenas productivas completas, evitando cualquier tipo de competencia. Por esta razón se suelen denominar también como prácticas absolutas. Se ha considerado a nivel mundial que este tipo de prácticas eliminan completamente la competencia, y que sus efectos siempre son nocivos tanto para el proceso económico, como para los consumidores, ya que suelen eliminar la eficiencia económica en esa área específica a largo plazo, manipulando los precios de venta y la calidad del producto, cuestión que afecta directamente a los consumidores. Prácticas desleales y prácticas restrictivas. Wltker, Jorge. Prácticas desleales y prácticas restrictivas En: Universidad Autónoma de México. Estudios en torno a la Ley Federal de Competencia Económica, 1994. p. 145.

3. El análisis de una conducta restrictiva de la competencia requiere previamente determinar cuál es el contexto competitivo al que se enfrenta la empresa objeto de investigación. Esto supone identificar el conjunto de productos (bienes o servicios) que rivalizan entre sí en la satisfacción de las necesidades de los consumidores, el conjunto de empresas que pueden ofrecer dichos productos en un plazo relativamente reducido de tiempo, y el área geográfica en la que las condiciones de competencia para el suministro de dichos productos son suficientemente homogéneas y diferentes de las de otras áreas geográficas próximas. En definitiva, la definición del mercado relevante es un instrumento que se utiliza para comprender el contexto en el que se desarrolla la rivalidad competitiva entre las empresas y, cuando menos, sirve para realizar una primera aproximación sobre el posible dominio de la empresa objeto de investigación. Jiménez, F. y Cañizares, E. (2005). Dificultades para la definición de mercado relevante. En: Segundo Seminario de Derecho y Economía de la Competencia. (18, octubre: Madrid, España). Memorias p. 1.
} 
Ahora bien, es posible identificar la presencia de prácticas que buscan manipular la competencia y el curso de las relaciones comerciales en diferentes épocas de la historia de la humanidad, lógicamente cada una de esas manifestaciones obedece al momento y sus específicas condiciones socioeconómicas y políticas. A continuación, siguiendo el análisis realizado por Carmen Herrera Suárez (2006, p. 59), se presenta una breve reseña sobre esta dinámica entre competencia y mercado.

- Durante la edad media las Corporaciones y los Municipios controlaban todos los aspectos relevantes del desarrollo de la actividad industrial y comercial -por ejemplo, el acceso al mercado y las cuotas de producción-. Adicionalmente, se conoce que en este periodo los gobiernos solían estar parcializados a favor de los comerciantes y los grandes empresarios (Heinemann, 2007, pp. 7-47) situación que facilitaba el avance de los acuerdos realizados entre ellos para manipular el mercado por medio de su división y la fijación de precios.

- Incluso, algunos estados consideraban que estos pactos no eran nocivos para su economía interna, por lo tanto, siempre que se realizaran en un marco de legalidad y no tuvieran un enfoque destructivo, podrían traer beneficios económicos dentro del país de origen (Fear, 2006, pp. 7-11).

- La Edad Moderna plantea un escenario diferente. Se evidencia un intervencionismo generalizado por parte de los poderes públicos, el cual se ve reflejado en reglas como la necesidad de autorización para la creación de compañías, el establecimiento de precios máximos de venta y la fijación de salarios. La negación de libertades y la clausura de los mercados, son algunos de los factores que no permiten afirmar la existencia de una disciplina de competencia en este tiempo.

- A finales, del Siglo XVIII, se publica la obra de Adam Smith “Investigación sobre la naturaleza y causa de la riqueza de las naciones (1776)", en la cual el autor censura el control gremial y gubernamental de la producción económica y defiende como forma más eficien- 
te de la asignación de bienes económicos a la interacción libre de productores y competidores en el mercado.

- Más adelante, en el Siglo XIX, el modelo de economía liberal, propone la consecución del bien común a través de la libertad y la actuación autónoma de los individuos. El mercado y la competencia tienen el objetivo de luchar contra las situaciones de poder que impiden la consecución del bien común, por esta razón se les da un papel central en la organización de la sociedad.

- En el contexto de la Revolución Industrial la competencia se encaminaba hacia su autodestrucción: acuerdos restrictivos, carteles, etc. Todas estas prácticas en contra del modelo de libertad.

- Más adelante, después de la Primera Guerra Mundial (1918) se deja de creer que la autonomía privada por sí sola podría lograr el bien común. Por esta razón, se da una vuelta hacia el intervencionismo estatal como mecanismo para garantizar el bienestar de la sociedad. En algunos estados se instauran posiciones extremas a este respecto.

- Finalmente, surge el derecho de la competencia con un doble cometido: la preservación del sistema de mercado y la tutela de las libertades económicas. En Estados Unidos su nacimiento se da hacia finales del Siglo XIX, como una respuesta al enorme grado de concentración empresarial y poder económico y político que estaban alcanzando los grandes grupos empresariales (trust), situación que condujo a la aprobación del Sherman Act en 1890.

De la exposición previa sobre la evolución histórica del derecho de la competencia y de la aparición de las prácticas que buscan restringirla, llama particularmente la atención el hecho de que para algunos gobiernos los carteles puedan significar la unión de esfuerzos de pequeños empresarios como estrategia corporativa para poder competir en el mercado, hasta el punto de verles como una estrategia legítima para acceder al comercio e industria internacional. Un claro ejemplo de esta situación se encuentra en la política de desarrollo industrial y económico que llevó a cabo el Estado japonés en el período de posguerra. 
Para este momento, la preocupación fundamental del gobierno nipón era evitar el estrangulamiento de las empresas y el declive económico, por lo cual apoyó conscientemente la instauración de carteles como mecanismo para restringir la competencia. A través de una burocratización se trazaron las políticas por parte del Ministerio de Comercio Internacional e Industria, las cuales consistían principalmente en:

(...) la intervención dentro de las organizaciones industriales para mejorar el bienestar económico, específicamente las políticas que pretenden intervenir en la estructura competitiva y reparto de recursos mediante carteles contra la recesión, la ley de medidas temporales para la estabilización de las Industrias especialmente estancadas (1978), la cual permitía línea de crédito especial y cártel contra la recesión para promocionar racionalización o para acelerar proceso de ajuste (textiles y acero). (Nishijima, 2009, p.11)

Sin embargo, la posición tomada por el gobierno japonés no es absoluta y cuenta con variedad de adversarios. En el caso de Smith, el autor afirma enfáticamente que los carteles son un "impuesto incoherente creado por orden de los hombres que tienen generalmente un interés de engañar e incluso oprimir a la opinión pública” (Fear, 2006, pp. 7-11).

Con lo expuesto hasta el momento, especialmente con lo relativo a la conceptualización que se ha presentado, es posible señalar que en relación con los carteles se evidencia "la existencia de una relación voluntaria, potencialmente no permanente, que existe entre un número independiente de negociantes y empresarios particulares, que al coordinar los precios del mercado, repartirse el mercado, entre otros, afecta de manera importante el mercado de cierto producto o servicio (Hexner, 1950, p. 40). En las siguientes líneas de este artículo, se realiza una explicación detallada de las principales características de los carteles. 


\section{I.I La existencia de un pacto.}

El pacto de voluntades entre los comerciantes que deciden constituir carteles podrá reposar en un convenio escrito o consistir en una cooperación efectiva no convenida formalmente. Acuerdo es básicamente una conjunción de voluntades expresa o tácita, por lo tanto, no constituye cartel una situación que no sea el resultado de una acción consciente, producida por mero azar o por una cooperación involuntaria (Cortazar, 2011, p. 59). Tampoco constituyen cartel las conductas realizadas por los particulares por mandato de la ley ${ }^{4}$.

El término convenio, no solo cubre los contratos legales, también incluye toda suerte de entendimientos comunes, obligatorios o tácitos, acerca de los hechos futuros y de ejecuciones o indulgencia. Se debe agregar a esta clase de convenios el llamado entendimiento honorable o pacto entre caballeros, pues aunque los interesados estén acordes en seguir cierta conducta, existe la reserva expresa o tácita de que la obligación descansa exclusivamente en la esfera moral, y por tanto, se está en presencia de acuerdos verbales (Hexner, 1959 p.38).

Las formas de acuerdos o vehículos conductores como se han denominado por la doctrina, que constituyen la forma en que se presenta el comportamiento restrictivo, pueden ser el contrato, el convenio, la concertación, la práctica concertada y la práctica conscientemente paralela.

Ahora bien, en relación con los acuerdos tácitos o conscientemente paralelos -como los ha denominado la doctrina-, es necesario realizar una suerte de precisiones para no confundir esta modalidad con los acuerdos verbales y recalcar que si bien son una figura particular -incluso atípica- también constituyen un acuerdo que entraña la expresión de la voluntad de las partes.

4. Un claro ejemplo de una conducta realizada por los particulares por el mandato de la ley es el Fondo de Estabilización de Precios del Azúcar, un mecanismo creado por el gobierno colombiano para mantener en equilibrio los precios del azúcar en el mercado doméstico. El mecanismo facilita el manejo ordenado de los excedentes exportables del producto al hacer indiferentes las ventas en el mercado doméstico frente a las realizadas en el mercado externo. Funciona con base en un precio de referencia y un flujo de dineros de compensación y cesión. 
Los acuerdos tácitos poseen varios elementos: un acuerdo consciente de las partes - y esa conciencia autónoma es la que permite entenderlo como una manifestación de su voluntad-, una conducta paralela y conjunta - en el sentido de que las decisiones no son tomadas de forma independiente- (Beltrán y Miranda, 2010, p. 5).

Alfonso Miranda y Daniel Beltrán (2010), proporcionan una definición clara y útil sobre las practicas paralelas, así: “en principio se entiende que esta existe cuando varias empresas presentan comportamientos coincidentes durante un periodo de tiempo determinado" (p. 3). Estos autores, hacen énfasis en el hecho de que ni la doctrina internacional sobre el derecho de la competencia ni tampoco la que ha venido construyendo la Superintendencia de Industria y Comercio (SIC) consideran que la ocurrencia de una conducta paralela pueda ser considerada por sí misma como una conducta violatoria del régimen de la libre competencia.

De manera que, una práctica paralela puede ser considerada como un acuerdo anticompetitivo, siempre que sea posible demostrar que los comportamientos han sido desplegados de manera consciente y conjunta:

Es decir, que no han adoptado sus determinaciones de manera unilateral y autónoma, sino en un ambiente de conocimiento y connivencia con sus competidores. En este sentido, las autoridades de competencia alrededor del mundo han establecido que los casos de paralelismo consciente se requiere demostrar, además del paralelismo, unos "Factores Plus" que no son otra cosa que indicios de la existencia de un acuerdo entre las compañías investigadas. (Miranda y Beltrán, 2010, p.5 )

No obstante el acento que se realiza sobre la importancia de la existencia del acuerdo para poder concluir que una conducta paralela constituye un acuerdo anticompetitivo, la Sala de lo Contencioso Administrativo del Consejo de Estado en Sentencia del 21 de Agosto de 2014 -Magistrada ponente, 
María Elizabeth García- al estudiar un proceso de nulidad y restablecimiento del derecho en el denominado caso de las "Estaciones de Servicio", concluye que de una conducta paralela y prolongada en el tiempo por parte de las empresas involucradas, que consistía en una igualdad en los precios de la gasolina extra, se puede inferir que existe un acuerdo indirecto entre ellas para la fijación de los precios, dicho de otra forma que las empresas se encontraban cartelizadas, generando por tal motivo una restricción a la libre competencia.

Para Miranda y Beltrán esta posición del Consejo de Estado, es desacertada y no concuerda con la doctrina del paralelismo consciente:

Frente a esta situación es importante recordarle a la autoridad de competencia y a los honorables Consejeros de Estado, que el paralelismo consciente es una modalidad de acuerdo, es decir, que la autoridad tiene la carga de demostrar "el encuentro de voluntades" de los competidores y la ausencia de independencia en la toma de las decisiones. Lo demás es una incorrecta aplicación de la doctrina del paralelismo consciente que nos llevará inexorablemente a los falsos positivos. (p.5)

En resumen, para el Consejo de Estado, la mera existencia de una conducta paralela sirve como prueba suficiente para poder afirmar la presencia de un acuerdo entre las partes para manipular el mercado, planteamiento que resulta peligroso, pues al realizar una conclusión de este alcance, basándose exclusivamente en la idea de que las conductas paralelas no podían ser simplemente coincidencia, sin más labor probatoria, se atenta contra la seguridad jurídica.

\section{I.2 La independencia de los involucrados.}

Para considerar que el comportamiento de un grupo de empresas obedece a la constitución de un cartel debe considerarse siempre lo siguiente: "cada uno 
de estos entes deberá poder actuar autónomamente en asuntos ajenos al acuerdo de cartel” (Hexner, 1950, p. 42), es decir, que mediante el o los acuerdos celebrados se modularán las voluntades de las participantes en búsqueda de su interés particular y la restricción de la competencia.

De forma tal que, cada una de las empresas cartelizadas tiene independencia, es decir, que cada una de ellas deberá tener una voluntad autónoma y no sujeta a una unidad de control, pues si se encontraran sujetas al dominio de un solo agente estarían autorizadas para comportarse en bloque y no competir entre las concentradas en los procesos de concentración económica autorizados (Hexner, 1950, p.42).

El cartel supone intereses económicos contrapuestos, mientras que en un grupo empresarial solo hay un único interés económico ya que se trata desde el punto de vista económico de una sola empresa, aunque jurídicamente son varias empresas. Además por tratarse de una sola empresa no hay incentivo para incumplir el acuerdo ya que dicho incumplimiento afectaría a todas las empresas del grupo (Barón, 2010, pp.105-106).

Por lo tanto, los grupos económicos ${ }^{5}$ constituyen un fiel reflejo de la existencia de una conducta paralela y conjunta por parte de un conjunto de empresas, la cual, sin embargo, no puede ser acusada de ser un acuerdo anticompetitivo. Adicionalmente, como en el grupo económico las empresas se encuentran autorizadas para actuar en bloque, tampoco se puede hablar sobre la existencia de un acuerdo.

El caso "Copperweld Group Vs. Independent Tube Corporation” constituye un ejemplo idóneo de que la actividad de los grupos económicos carece de la condición necesaria de la autonomía, propia de los carteles. En esa oportunidad la Corte Suprema de Estados Unidos explicó que entre una ma-

5. En Colombia, por ejemplo, si las empresas cárnicas del grupo económico Nutresa (Industria de Alimentos Zenú S.A.S, Alimentos Cárnicos S.A.S, Setas Colombianas S.A) decidieran fijar un margen a sus precios de venta, esta conducta no podría ser tomada como un acuerdo restrictivo de la competencia o cartel. 
triz y su subsidiaria de propiedad total existe una unidad de intereses y de objetivos que son guiados y determinados por una misma conciencia corporativa, por lo cual la actividad coordinada entre ellas debe ser vista como la actividad de una sola empresa.

\section{I.3 El comportamiento voluntario, intencional y coordinado.}

Debe existir un comportamiento voluntario, intencional y coordinado (paralelismo) dedicado a la fijación de los precios del mercado, repartición de mercado etc., que afecta de manera importante el mercado de cierto producto o servicio (Hexner, 1950, p. 49).

\section{I.4 La inestabilidad potencial.}

Habrá una presencia de inestabilidad potencial puesto que las relaciones suscitadas por los carteles podrán perdurar durante varios años mediante una renovación continua; sin embargo, rara vez se estipula un convenio por un término superior a 5 años. Aun cuando se emplean contratos obligatorios, los depósitos y otros medios destinados a vigorizar las relaciones de los carteles, habitualmente se permite el retiro de un participante sin que sufra ninguna consecuencia legal (Hexner, 1950, p. 49).

\section{I.5 Planeación anticipada e intencional de ventajas y des- ventajas.}

Se deberá presentar una planeación anticipada e intencional de ventajas directas o indirectas en favor de los participantes. Las relaciones originadas por los carteles sirven a los intereses reales o imaginarios de sus adheridos. La mayoría de empresarios particulares justifican la renuncia de su libertad, arguyendo que a la larga resulta más ventajoso para el público y para ellos mismos 
evitar ciertos riesgos mediante la cooperación de los demás negociantes, que si soportara el solo la competencia.

Así mismo, erróneamente se ha considerado que al enfrentarse a crisis las empresas pueden entrar en acuerdos que restringen la competencia, pues debido a la situación empresarial se genera una inmunidad de reclamo de infracción por las normas de competencia (carteles en crisis) (Vitzilaio, 2011, p. 5). Es posible, que de forma equivocada, esta práctica se haya derivado de lo sucedido en Japón frente al tema de la cartelización como forma de proteger la economía local en el período de la posguerra.

\subsubsection{Los carteles no tienen que producir efectos reales.}

No es necesario que produzcan efectos reales para que los acuerdos se consideren carteles. Esto quiere decir que las conductas de cartelización pueden ser castigadas por objeto o por efecto, es decir, que si dos empresas establecen contactos con objeto de restringir la competencia, la prohibición se aplicará aun cuando los efectos de dichos contactos no se materialicen en el mercado (Velandia, 2011, p. 125).

Ha de tenerse presente que

(...) al sancionar los carteles por objeto, es decir, por tentativa o ex ante se tiene en cuenta la intención de causar daño (dolo); sin embargo, al sancionarlos ex tunc, o por efecto, lo que se castiga es la falta de diligencia en observar el resultado, o la culpa grave, sin importar que los agentes contaran con la intención del resultado. (Velandia, 2011, p.126) 


\section{I.7 Que la no competencia genere beneficios.}

Los acuerdos celebrados buscan beneficiarse del mercado sin que exista competencia que pueda poner en riesgo esta finalidad. Con este específico propósito los competidores utilizando las diferentes formas de cartelización realizan alianzas que en la mayoría de los casos obedecen a las siguientes modalidades: adoptando un precio unificado; asignando cuotas de producción o suministro, por medio de las cuales reducen la producción o cantidad de suministro del producto para generar escasez que incremente el precio; acordando la repartición de mercado para que cada uno de los miembros del cartel abastezca uno de los sectores geográficos o de consumidores (Perilla, 2007, pp. 394-426).

\section{Formas y clases de carteles}

Las diferentes clases de acuerdos de cartel pueden presentarse de diferentes formas, ya sea fijando precios, condiciones de venta, comercializaciones discriminatorias, repartiéndose los mercados, asignándose cuotas de producción y distribución, reduciendo la oferta, y generando ventas atadas o subordinadas, entre otras. Durante el desarrollo de esta investigación, ha sido posible identificar de la información arrojada por el análisis de los casos de estudio y de la doctrina respectiva, que los vehículos más usados son los acuerdos sobre fijación de precios, la repartición de mercado, y la asignación de cuotas de producción y distribución.

\section{I. Sobre la fijación de precios}

Respecto a la fijación de precios cabe mencionar que la finalidad de esta forma de cartelización es maximizar las ganancias de las empresas cartelizadas, ya sea fijando precios idénticos o desiguales que crean un carrusel artificial de subida, fijando precios de techo o máximo de venta, fijando precios de piso o mínimos de venta, realizando acuerdos de franja de precios para precisar un 
máximo o un mínimo, o estableciendo una variable para el aumento de precios (Velandia, 2011, p. 136).

A nivel internacional, vale la pena mencionar los carteles de la lisina, las vitaminas y la industria LCD:

- En el caso del cartel de la lisina, se tiene que su operación duplicó el precio mundial de este producto durante el tiempo que se mantuvo activo hasta el momento de su sanción en 1996. Cinco de las empresas que participaron en el cartel fueron sancionados por el Departamento de Justicia de los Estados Unidos, así como varios de sus directivos. El cartel de la lisina conllevó al endurecimiento de las políticas contra los acuerdos anticompetitivos, además generó múltiples sanciones en diferentes países afectados. (Organización Mundial del Comercio, 2012, p. 57)

- El cartel internacional de las vitaminas "ha sido el de mayor envergadura que haya sido descubierto y sancionado” (González, 2007, p. 7). Las actividades de este cartel abarcaban al menos 12 variedades de vitaminas, entre las cuales se cuentan la $\mathrm{A}$ y E, elementos que resultan vitales para la nutrición y además hacen parte de una gran gama de productos alimenticios y farmacéuticos de alto consumo. Durante aproximadamente 10 años, la operación de este cartel, compuesto por 13 empresas, desplegó una práctica restrictiva de la competencia, mediante la fijación de precios y la asignación de cuotas de mercado - prácticas que eran vigiladas por la organización y cuya falta de aplicación generaba sanciones internas-(González, 2007, p. 7).

En Estados Unidos y en Europa, las investigaciones condujeron a la sanción de las firmas participantes en el cartel, siendo Hoffman, la Roche y Basf las más perjudicadas, por cuanto su participación en el mercado era la más alta y por eso eran las más beneficiadas con la cartelización; además las tres compañías actuaron como líderes y promotoras de las prácticas anticompetitivas. En otros países del globo, también se han sancionado las actividades 
de este cartel e incluso se han realizado acuerdos extraprocesales o contencioso ordinario. (Creus, 2014, p. 1)

En el marco del cartel de las pantallas TFT-LCD, varias industrias fabricantes de pantallas que poseen esta tecnología se unieron con la finalidad de aumentar sus precios de venta para los clientes fabricantes de bienes finales. Empresas como Samsung Electronics, LG, Epson e Hitachi, entre otras, fueron sancionadas tanto en Estados Unidos como en Europa. Se calcula que el tiempo aproximado de duración de este cartel fue de 3 años (2000-2003) (Superintendencia de Industria y Comercio, 2013, p. 26).

En Colombia la SIC abrió una investigación que buscaba sancionar los efectos de dicho cartel internacional en el mercado relevante del país, sin embargo, por medio de la Resolución 5413 de febrero de 2013, la misma entidad decide archivar el proceso por caducidad en la acción (Superintendencia de Industria y Comercio, 2013, p. 26).

A nivel nacional encontramos el cartel del papel higiénico. Las empresas Kimberly, Familia, Papeles Nacionales y Cartones y Papeles de Risaralda (CYP del R), realizaron durante aproximadamente trece años (2000-2013) una conducta concertada, continuada y coordinada para fijar el precio de los papeles suaves en Colombia, conformado por: papel higiénico, servilletas, toallas de cocina y pañuelos para manos y cara. En este caso, por medio de la Resolución número 31739 del 26 de mayo de 2016, la Superintendencia sancionó a Kimberly, Familia, Papeles Nacionales y CYP del R. (Superintendencia de Industria y Comercio, 2016).

\subsection{Sobre la repartición de mercados}

De igual manera, los carteles pueden tener como objetivo una repartición de mercados, esto es, la distribución entre productores o distribuidores del mercado, creando barreras y limitando las posibilidades de escogencia o de compra. 
Esta forma de cartel, puede presentarse por la repartición de mercados vía zonas o territorios, mediante la adjudicación de un lugar específico donde puedan comprar o vender sus productos, a través de la repartición del mercado vía demanda o de clientes, dividiéndose la clientela y limitándose a dirigir su oferta a ciertos potenciales compradores; con la repartición vía productos, asignándose líneas de producción entre empresas; y repartición de la oferta o de vendedores cuando los compradores son empresas que acuerdan a quién comprar (Velandia, 2011, pp.141-146).

Dos ejemplos, uno a nivel internacional -el cartel de los grafitos- y el otro a nivel nacional-el del cartel del cemento-, permiten dar una perspectiva práctica de la cartelización mediante la repartición de mercados.

En el caso de los electrodos de grafito, varios productores y exportadores realizaron un acuerdo sobre los precios de venta para el producto con el objetivo de repartirse el mercado, aumentar los precios y limitar la capacidad de producción de otras empresas y generando un mercado cautivo de consumidores en diferentes países. Sanciones económicas por parte de Estados Unidos y la Unión Europea, entre otros países, así como el encarcelamiento de algunos ejecutivos de las empresas con mayor liderazgo e influencia dentro del cartel, son algunas de las consecuencias previstas para sus actividades restrictivas de la libre competencia (Secretaría de Economía, 2012).

Frente al caso del cemento, en Colombia se han adelantado 5 investigaciones por presunta cartelización en el sector, las tres primeras no se sancionaron, la cuarta si generó una sanción, pero fue revocada por el Tribunal Administrativo de Cundinamarca, por temas procesales de caducidad. En la actualidad, la Superintendencia de Industria y Comercio se encuentra adelantando la quinta investigación. Es así como, por medio de la Resolución No. 49141 del 21 de agosto de 2013, la Entidad formuló pliego de cargos contra cinco empresas cementeras del país, y catorce directivos de dichas compañías, cargos que apuntan principalmente a la repartición del mercado y el incre- 
mento sostenido e injustificado en los precios del cemento gris desde enero de 2010 (Superintendencia de Industria y Comercio, 2013, p.85).

\subsection{Sobre la asignación de cuotas}

Los acuerdos restrictivos de la competencia también pueden presentarse como asignación de cuotas que busquen fijar unidades de producción o distribución de cada uno de los entes cartelizados. Esto que genera que se produzca un número de bienes generalmente inferior al nivel de demanda para subir el precio, asignando a cada partícipe una cuota de producción por empresa o de distribución (Velandia, 2011,pp. 146-147).

En este caso a nivel nacional se encuentra el reconocido caso del cartel del azúcar. Por medio de Resolución número 80847 del 7 de octubre de 2015 la SIC sancionó a Asociación de Cultivadores de Caña de Azúcar de Colombia-ASOCAÑA-, C.I. DE AZUCARES Y MIELES S.A -CIAMSA-, DICSA y doce ingenios azucareros por haber incurrido durante varios años en una conducta concertada, continuada y coordinada para obstruir importaciones de azúcar, así como asignación de cuotas de producción y distribución (Superintendencia de Industria y Comercio, 2015).

Una vez sentados las principales características de las formas más comunes de cartelización, a través de su definición y de la presentación de casos ilustrativos, es el momento de entrar a explicar la clasificación de los carteles. En este orden de ideas se reconocen a nivel internacional las clases de carteles que se describen a continuación.

\subsection{Los carteles de importación}

Son aquellos que tienen por objeto fijar el precio $u$ otras condiciones relativas a los bienes o servicios que se importan con destino a los mercados internos 
de las empresas participantes (Organización Mundial del Comercio, 2002, p. 2). Estos carteles actúan frecuentemente como organizaciones que centralizan las compras para el suministro de materias primas e insumos a una industria. Pueden también establecerse para contrarrestar el poder en el mercado de los carteles de exportación de otros países (Conferencia de las Naciones Unidas sobre Comercio y Desarrollo, 1996, p. 2).

Un ejemplo de esta forma de cartel en el país, es el ya mencionado caso del cartel del azúcar, sancionado por la Resolución número 80847 del 7 de octubre de 2015. La Asociación de Cultivadores de Caña de Azúcar de Colombia-ASOCAÑA-, C.I. de Azucares y Mieles S.A -CIAMSA-, DICSA y doce Ingenios Azucareros habían incurrido durante varios años en una conducta concertada, continuada y coordinada para obstruir importaciones de azúcar de otros países hacía Colombia, específicamente de Bolivia, Guatemala, El Salvador y Costa Rica. Varios correos electrónicos, entre las diferentes organizaciones del sector, le sirvieron como prueba a la SIC para encontrar que este cartel del azúcar, tenía entre sus propósitos cerrar la puerta a las importaciones de azúcar.

\subsection{Los carteles internacionales}

Los internacionales, son aquellos carteles que se presentan cuando empresas de diferentes países se unen para fijar los precios, los volúmenes de producción u otros factores determinantes de la competencia en diversos mercados nacionales, incluidos por lo general, aunque no exclusivamente, los países de origen de las empresas participantes (Organización Mundial del Comercio, 2002, p. 2).

Entre los casos que sirven de ejemplo para ilustrar esta clase de cartel, que ya ha sido objeto de explicación en los párrafos precedentes, se encuentran: el cartel de las vitaminas, el de la lisina, el de las pantallas LCD y el de los electrodos de grafitos. 


\subsection{Los carteles de exportación}

Estos carteles obedecen a acuerdos entre empresas que buscan exportar conjuntamente un determinado bien, con la intención de cobrar un precio de exportación previamente establecido y/o dividir los mercados de exportación (Khemani, Shapiro, 1991, pp. 8-9); estos son los que fijan precios o volúmenes de producción en los mercados de exportación de las empresas participantes, pero no en sus mercados internos (Ibarra, 2006, pp. 153-215).

Los carteles de exportación se dividen en dos grupos: los puros que aplican sus esfuerzos exclusivamente a los mercados extranjeros, mientras que existen los mixtos los cuales limitan la competencia tanto en el mercado del país exportador como en los mercados extranjeros (Atwood, 2006, p. 154).

Los carteles de exportación mixtos afectan tanto el mercado nacional como el mercado receptor de las exportaciones, por tal razón, de forma general, la normativa aplicable en estos casos puede ser cualquiera de las dos, de acuerdo con lo planteado por la teoría de los efectos. Ahora bien, las condiciones de los carteles de exportación puros son muy diferentes, por lo tanto, son los carteles que mayor problema encierran en relación con la ley que se les puede aplicar, dado que no afectan el mercado nacional, sino solamente el exportador, por lo que en principio se encontrarían por fuera de la aplicación de normas nacionales.

El caso de los sobres de papel para votaciones es un buen ejemplo de un cartel de exportación puro. Entre los competidores del sector, realizaron un pacto que tenía como finalidad fijar los precios y repartirse el mercado de exportación de sobres de papel a determinados países, principalmente de Oriente Medio y a algunos de la Unión Europea. Las empresas se reunían y coordinaban a través de otra que fue creada para este fin: Hispapel. El consejo de la Comisión Nacional de la Competencia de la Unión Europea consideró acreditado que el comité ejecutivo de Hispapel, formado por los principales competidores en este mercado, era el foro en el que se intercambiaba información sensible y se adoptaban los acuerdos (Soto, 2013, p. 1). 


\section{Alcance de los carteles de exportación}

Estos carteles de exportación revisten gran importancia a nivel internacional, pues sus efectos se producen en un país diferente en el que se originan los acuerdos, es por ello, que teniendo en cuenta la territorialidad de las funciones estatales, el ámbito de aplicación de la normativa de derecho de la competencia-que en la mayoría de los casos combate las prácticas que tienen efecto en el mercado donde se originaron las mismas-, las restricciones presupuestales y de infraestructura existentes para perseguir estas conductas (Ibarra, 2006, pp. 153-215), resulta complejo determinar bajo los preceptos de cuál ordenamiento jurídico se pueden sancionar.

Esa dificultad, que resulta de la necesidad de identificar cuál ley puede ser aplicable en caso de conflicto y de la presencia de prácticas restrictivas de la competencia, tiene un impacto nacional e internacional en las actividades de comercio internacional que se realizan con estas características, por lo cual, resulta importante realizar un análisis más detallado del tema. De igual manera, el asunto toca de forma sensible la situación de los países en desarrollo frente a la posibilidad de aplicar sanciones que resulten vinculantes a empresas y grupos económicos de gran poderío, provenientes de las naciones del primer mundo.

Como bien lo expone Perilla (2007, pp. 394-426), a nivel internacional se ha considerado por la gran mayoría de legislaciones que los carteles de exportación puros se encuentran fuera del ámbito del derecho de la competencia por dos razones:

1. Porque en el caso de no tener en cuenta la teoría de los efectos, los mismos se encontrarían por fuera del alcance de las leyes internas en materia de competencia.

2. Porque en algunos casos se encuentran expresamente exentos de la aplicación de las leyes, como ocurre con Estados Unidos como consecuencia de lo prescrito por el Webb Pomerene Act de 1918. De 
acuerdo con esta Ley, y con otras de este tipo que se fundamentan en la doctrina de la teoría de los efectos, los exportadores estadounidenses pueden estar libres de reproche en ese país, por cuanto las conductas negativas de sus prácticas anticompetitivas se generan en otros estados distintos al americano, siempre que sus consecuencias "no tengan efectos directos, sustanciales y razonablemente previsibles en el comercio de ese país” (Perilla, 2007, p. 449).

Las opiniones sobre la existencia de los carteles de exportación están divididas, algunos piensan que sus efectos son positivos, mientras que la posición mayoritaria sostiene que perjudican ostensiblemente el mercado global (Jesen-Eriksen, 2010, p. 7). Algunos de los argumentos planteados por quienes consideran que los carteles de exportación tienen efectos positivos, son descritos en las líneas a continuación:

1. De acuerdo con lo planteado por la teoría de la política comercial, un cartel de exportación es una estrategia que facilita a las empresas exportadoras, el ejercicio de poder dentro del mercado. Para que esta doctrina se lleve a cabo, algunos estados exoneran a los carteles de exportación, de la aplicación de su legislación nacional (Desmarais, 2003, pp. 8-11).

2. La teoría de la eficiencia de las ganancias estratégica, señala que un cartel de exportación genera ganancias de eficiencia mediante la reducción de los costos relacionados con la venta en los mercados extranjeros (Desmarais, 2003, pp. 8-11).

3. Brendan Sweeney, sostiene que cuando el cartel está conformado por pequeños empresarios, su propósito es aumentar el valor de las exportaciones, mediante la reducción de costos y riesgos, al igual que propiciando la mejora de los productos. Para el autor JesenEriksen, estos carteles aumentan la competencia y benefician a los clientes extranjeros (2010, p. 20).

4. Andrew Dick, apoyándose en un estudio que realizó en Estados Unidos sobre 16 carteles de exportación del país, encontró que 
este tipo de acuerdos pueden generar eficiencia (Jesen-Eriksen, 2010, p. 12).

5. Países como Thailandia, India y China han sostenido que "si no existen carteles de exportación resulta difícil para las pequeñas empresas entrar a exportar” (Jesen-Eriksen, 2010, p. ).

6. John R. Magnus -Abogado estadounidense dedicado a asesorar a empresas cartelizadas- sostiene que el intercambio de las economías de escala y costo alcanzable a través de la comercialización conjunta de las exportaciones producen grandes ahorros. La reducción de costos genera crecimiento del mercado y precios bajos para los consumidores de todo el mundo (Jesen-Eriksen, 2010, p. 13).

7. Matti Purasjoki, quien durante su época como Director General de la Autoridad de la Competencia de Finlandia trabajó duro para descubrir y destruir los carteles entre 1988 y 2004, admitió en el final de su carrera que el "crecimiento de Finlandia en la posguerra no habría sido posible sin carteles” (Jesen-Eriksen, 2010, p. 14), pues permitió que sus productos se empezaran a exportar, lo cual hubiera sido imposible teniendo en cuenta el tamaño de sus empresas.

De manera, que como lo expresa Desmarais, la justificación para la existencia de los carteles de exportación, recae en una concepción parcializada del sistema internacional, con una lógica a priori, la cual tiene por objeto proteger la eficiencia del mercado interno:

Estos planteamientos simplemente hacen caso omiso de los efectos adversos que pueden traer los carteles a la competencia, pasando por alto si dichos efectos tienen alcance extraterritorial y si pueden afectar los mercados nacionales, sobre todo en los países en desarrollo. Son concepciones en las que se excusan algunos estados, para buscar únicamente su propio interés, lo cual es contrario al sistema de comercio mundial basado en el principio de que el mundo está mejor sin barreras artificiales al comercio y en el que la competencia se maximiza (Desmarais, 2003, p.8). 
A contrario sensu, la posición mayoritaria sostiene que los carteles de exportación van en contravía del bienestar económico de los países, dada la magnitud de sus consecuencias (Stephan, 2010, pp. 1-3). Siguiendo lo propuesto por Stephan, algunos de los efectos adversos de estos pactos, que más influyen en el mercado moderno se pueden resumir de esta manera:

1. Representan un obstáculo para el logro de un sistema de libre comercio, en la medida que restringen el flujo de bienes y servicios,

2. Distorsionan el comercio internacional mediante la fijación de precios,

3. Limitan la libre competencia y someten a los consumidores a pagar altos precios,

4. Limitan la cantidad de exportaciones,

5. Conducen a una desliberalización del comercio internacional, poniendo en riesgo el desarrollo económico, entre otros factores,

6. Debilitan las políticas comerciales internacionales, que promueven la integración de los mercados y la libertad del comercio internacional.

Como lo indica la OCDE, los carteles de exportación afectan particularmente a los países en desarrollo pues perturban el precio y el suministro de los insumos utilizados por las industrias menos desarrolladas, pueden incurrir en prácticas monopólicas en contra de sus competidores menos potentes (los países en desarrollo), y las asignaciones del mercado a los miembros de otros estados, afectan los intereses internos de cada país donde opera el cartel ${ }^{6}$.

\footnotetext{
6. El proteccionismo de algunos estados promueve las exenciones de los carteles de exportación, mediantes los acuerdos comerciales bilaterales o multilaterales; como en el Acuerdo Norteamericano de Libre Comercio entre el Gobierno de Canadá, el Gobierno de México, y el Gobierno de los Estados Unidos.(Artículo 48 Capítulo 15 (B) de la Ley de Implementación del Tratado de Libre Comercio de América del Norte Estados Unidos sostiene que: "No hay cambios en las leyes antimonopolio de los Estados Unidos, incluyendo la Export Trading Company Act de 1982 o la Ley Webb-Pomerene, estarán obligados a cumplir con las obligaciones de Estados. Unidos bajo el TLCAN. Estas leyes han contribuido a la competitividad de las exportaciones de las industrias de Estados Unidos y siguen siendo apropiados en el contexto de una zona de libre comercio. Ninguna disposición del Acuerdo exige que cualquier gobierno TLCAN para tomar medidas que afecten negativamente a este tipo de asociaciones)”. Desmarais, F. 2003. p. 3.
} 
Como se puede ver, de forma general, estos carteles no afectan directamente la economía del mercado en el que se realiza el pacto o acuerdo que tiene por objeto la restricción del comercio por medio de acuerdos de precio, la repartición de mercado, entre otras conductas, más bien su impacto se produce en los mercados extranjeros cuando ingresan los bienes o servicios de las empresas cartelizadas, en donde sus efectos generarán una exclusión de competidores, que afectará directamente a los consumidores.

\section{Efectos de los carteles en el marco de un tratado de libre comercio}

El debate sobre los carteles de exportación dio lugar a un nuevo punto de referencia en cuanto al análisis del impacto producido por las prácticas anticompetitivas sobre el bienestar de las naciones, pues la globalización requiere de un nuevo criterio de bienestar global, el cual debe prohibir toda práctica restrictiva del comercio, independientemente de dónde se surta el efecto (Gonta, 2010, p. 17).

Es claro que estos carteles benefician a los países donde se albergan, siempre que cualquier efecto negativo sobre los consumidores sea pequeño y se encuentre compensado con las ganancias de los productores provenientes de su habilidad de incrementar los precios en los mercados extranjeros; sin embargo, esto irá en contra del bienestar extranjero si los costos de los consumidores sobrepasan el incremento en el excedente de los productores locales (Hoekman y Holmes, 1998, p. 3).

Este tema ha adquirido especial relevancia a partir del proceso de globalización, debido a que varios países han decidido reglamentar sus relaciones comerciales por medio de Tratados de Libre Comercio, con los que se busca incrementar los flujos de comercio e inversión, con la implementación de normas y procedimientos tendientes a garantizar que los flujos de bienes, servicios e inversiones entre los países que suscriben dichos tratados se realicen sin 
restricciones injustificadas y en condiciones transparentes y predecibles ( $\mathrm{Mi}$ nisterio de Comercio, Industria y Turismo, 2004, p. 5); por esto, resulta contraproducente que dentro de uno de los mercado pertenecientes a la zona de libre comercio se realicen pactos sobre la comercialización de productos en los mercados extranjeros buscando su beneficio particular.

En estos casos, es posible que aparezcan acuerdos de cartelización variados, y en la mayoría de los casos disímiles a las generalmente conocidas en los contextos domésticos, lo que finalmente genera un beneficio particular a los entes cartelizados, pues no resultan fácilmente identificables.

Así mismo, ha de tenerse en cuenta que estos acuerdos son realizados por empresas con cierto poder de mercado, incluso con posición de dominio -ya sean nacionales o multinacionales-, las cuales debido a su concentración nacional e internacional deciden acordar condiciones particulares de ingreso a mercados; por ello, podría pensarse que en la zona de Libre Comercio este tipo de pactos podrían celebrarse en su mayoría por parte de entes multinacionales o pertenecientes a países económicamente poderosos, que encontrarían atractivo ingresar a mercados emergentes mediante acuerdos que garanticen su “éxito" dentro del mercado nacional más débil.

En consecuencia, se tiene que en el marco de un Tratado de Libre Comercio, los carteles de exportación pueden convertirse en una barrera de acceso al mercado de la zona de libre comercio, pues los competidores serán excluidos por los entes cartelizados, y por lo tanto serán directamente los consumidores quienes deberán asumir el alza en los precios, por cuanto las ganancias obtenidas no les serán trasladadas. Dicho de otra forma, con la existencia de estos acuerdos se pierde la multiplicidad de oferentes de bienes y servicios, al igual que las mejoras en precios, variedad de productos y calidades para los consumidores, tal como lo ha afirmado la Superintendencia de Industria y Comercio (Superintendencia de Industria y Comercio, 2004, pp. 1-35). 
La sanción de los carteles de exportación ha cobrado vital importancia actualmente en Colombia, luego de la celebración de varios Acuerdos Comerciales con diferentes países. Esto es así, ya que se ha considerado por parte de algunos autores que la apertura de la economía implica para la industria doméstica una serie de conductas foráneas variadas que la distorsionan, así como la desviación de los beneficios que tendrían los consumidores, de forma tal que terminan reproduciéndose automáticamente las barreras eliminadas (Ibarra, 2006, pp. 153-215).

La experiencia indica que en la medida en que se eliminan las barreras arancelarias y demás obstáculos gubernamentales al comercio, los particulares tienden a reproducir la segmentación de los mercados previamente existentes, mediante conductas anticompetitivas y restrictivas de la competencia. Tan es así, que la liberalización puede fortalecer a los mercados imperfectos a nivel nacional e internacional, dado que el exceso de la competencia global puede llevar a los pequeños y nuevos inversores a adherirse a los carteles, ya que les puede resultar más rentable que competir (Martínez, 2013, p. 3).

Así las cosas, se tiene que para asegurar una competencia leal y justa, exenta de distorsiones, se requiere fijar unas reglas de juego que obedezcan a las necesidades particulares de cada esquema de integración, así como de unas instituciones sólidas con poderes suficientes para aplicar las normas respectivas (Ibarra, 1995, p. 62). 


\section{Conclusiones}

Las prácticas restrictivas de la competencia a nivel global, dentro de las cuales se encuentran los carteles de exportación, generan efectos adversos al comercio, pues su finalidad consiste precisamente en restringir la libre competencia. De forma particular, se tiene que los carteles de exportación pueden afectar simultáneamente tanto el mercado exportador como el mercado de origen, caso en el cual se estaría en presencia de un cartel mixto o, por el contrario, perjudicar solamente el mercado extranjero en donde se producen los efectos, más conocidos como carteles puros.

Teniendo en cuenta que estos carteles generan una mayor afectación en el mercado exportador, la tesis relativa al lugar de los efectos define, en principio, el régimen jurídico aplicable a los mismos. No obstante, la aplicación de esta tesis ha generado diversos inconvenientes ya que ha sido considerada agresiva por la comunidad internacional por interferir en las prerrogativas e independencia de los diferentes países, por lo anterior, para proceder a su aplicación se han definido claramente sus alcances por algunas legislaciones internas de países, como ocurre en el caso norteamericano.

Así mismo, debe considerarse que en el caso Colombiano no existe regulación alguna que determine el ámbito de aplicación de la teoría de los efectos. En lugar de esto, las leyes de competencia dejan abierta la posibilidad de su aplicación extraterritorial sin lugar a especificación alguna. En igual medida no existe jurisprudencia al respecto que pudiera aclarar los interrogantes que surgen sobre la extraterritorialidad de la legislación de competencia colombiana. 


\section{Referencias}

Atwood, J. R. (1988). Conflicts of jurisdiction in the antitrust field: the examples of export cartels. Law and contemporary problems. 50 (3), 153-155.

Barón, G. (2010). El derecho de la competencia en los grupos empresariales. (1 $1^{a}$ Ed.). Bogotá: Grupo Editorial Ibáñez. ISBN 978-958-8381-99-2.

Beltrán, D. y Miranda, A. (2010). El mero paralelismo de precios no equivale a un cartel. Bogotá: Centro de Estudios del Derecho de la Competencia.

Bouza, R y French-Davis, R. (2008). La globalización y la gobernabilidad de los paises en desarrollo. Revista Cepal. No. Extraordinario.

Conferencia de las Naciones Unidas Sobre Comercio y Desarrollo. (1996). La política de la competencia y las prácticas comerciales restrictivas. Informe de la secretaría de la UNCTAD. Ginebra: UNCTAD. Serie de informes técnicos: TD/B/RBP/INF.

Congreso de Derecho Comercial. (11 de octubre 2013). El TLC y el derecho de la distribución comercial: canales de distribución comercial y competencia. (1 ${ }^{a}$ Ed.). Medellín: Colegio de Abogados de Medellín, Cámara de Comercio de Medellín, Universidad Externado de Colombia. ISBN 9588235529.

Cortazar, J. (2011). Curso de derecho de la competencia. Bogotá: Pontificia Universidad Javeriana. ISBN 978-958-350-853.

Creus, A. (2014). Carteles internacionales. Fundación Rafael del Pino. Recuperado el 28 de mayo de 2015 de http://www.frdelpino.es/wpcontent/uploads/2014/10/es_03-Creus.pdf.

Desmarais, F. (2003). Export cartels in the americas and the OAS: Is the harmonization of national competition laws the solution? Manitoba Law Journal,37 (número), xx-xx 
Fear, J. (2010). Cartels and competition: neither markets nor bierarchies. Working Paper Harvard Business School. HBS Working Paper Number: 07-011.

Gonta, C. (2010). Export cartels a century of fumble attitudes?. Law.. (11). González, A. (2007). La delación compensada o amnistía en la lucha anticarteles. Trabajos de Investigación en Políticas Públicas. Universidad de Chile. Santiago de Chile, Chile.

Heinemann, A. (2007). La necesidad de un derecho mundial de la competencia. Revista Internacional Foro de Derecho Mercantil. (15),. 7-47.

Herrera, C. (2006). Los contratos vinculados (Tying Agreements) en el derecho de la competencia. Madrid: Editorlia La Ley.

Hexner, E. (1959). Carteles Internacionales. Ciudad de México: Fondo de Cultura Económica.

Hoekman, B. y Holmes, P. (1998). Política de competencia, países en desarrollo y la OMC. Taller de competencia y comercio (4: 4-5, diciembre: Venecia, Italia).

Ibarra, G. (1995). Regímenes de competencia y politicas de competencia en América Latina. Competencia y competitividad en áreas económicas integradas: procesos y experiencias en la Unión Europea y América Latina. Recuperado el 6 de junio de 2015 en http://cefir.org.uy/wpcontent/uploads/2009/07/DT_09.pdf .

Ibarra, G. y Miranda, A. (1999). La práctica de fijación unilateral de precios y su aplicación en Colombia. Bogotá: Centro de Estudios de Derecho de la Competencia.

Ibarra, G. (2006). El derecho de la competencia en las relaciones comerciales internacionales. Derecho de la Competencia, 2 (2), 153-215.

Jensen-Eriksen, N. (26-28 de agosto 2010). Predators or patriots? Export cartels as a source of power for the weak. $14^{\text {a }}$ Conferencia Anual de Historia Europea de la Empresa. Glasgow, Escocia. Paper. Glasgow: Universidad de Helsinki.

Jimenez, F. y Cañizares, E. (18 de octubre 2005). Dificultades para la definición de mercado relevante. Memorias del Segundo Seminario de Derecho y Economía de la Competencia. Madrid, España. 
Khemani, R.S. y SHapiro, D. M.(1991) Glosario de términos relativos a la economía de las organizaciones industriales y a las leyes y politicas sobre competencia. Paris: Organización para la cooperación y el desarrollo económico.

Koch, F. E. (1945). Cartels as instruments of international economic organization: public and private legal aspects of international cartels. Modern Law Review, 8(3), 130-148.

Levy, S. (2003). Globalización Económica. México: Isef. ISBN 9706764534. Martínez Licetti, M. (2013). Combating cartels in developing countries: implementation challenges on the ground. Competition Policy International,. 12 september 2013. Available at SSRN: https://ssrn. com/abstract $=2345402$

Ministerio de Comercio, Industria y Turismo. (Junio 2004). Las 100 preguntas del TLC. (1 ${ }^{a}$ Ed.) Bogotá: Ministerio de Comercio, Industria y Turismo Oficina de Comunicaciones.

NACIONES UNIDAS (2011). Informe. de la Sexta Conferencia de las Naciones Unidas Encargada de Examinar Todos los Aspectos en Conjunto de Principios y Normas Equitativos Convenidos Multilateralmente para el Control de las Prácticas Restrictivas. Ginebra, Suiza.

Nishijima, S. (2009) Desarrollo Económico y Política Industrial del Japón: implicaciones para países en desarrollo. Ribe Discussion Paper Series, (246). Organización Mundial del Comercio. (20 de junio 2002). Grupo de Trabajo sobre la Interacción entre Comercio y Politica de Competencia. Ginebra, Suiza. Nota documental de la secretaría. Ginebra: WT/ WGTCP/W/191.

Organización Mundial del Comercio. (2012). Combating anti-competitive practices: A guide for developing economy exporters. Genova: International Trade Center.

Perilla, C. (2007). Carteles de exportación y derecho de la competencia en el TLC. En, El tratado de libre comercio, la integración comercial y el derecho de los mercados (pp. 405-441). Bogotá: Universidad Colegio Mayor de Nuestra Señora del Rosario. 
Ramírez, G. (2007). Transformaciones del constitucionalismo en el contexto de la globalización. El derecho en el contexto de la globalización. Bogotá: Universidad Externado de Colombia.

Rubio Escobar, J. (2007). Derecho de los mercados. Bogotá: Legis.. ISBN 978-958-653-615-8.

Secretaría Económica Mexicana. (2012). Resolución del 22 de Febrero de 2012. Por medio del cual se toma una decisión de una investigación preliminar antidomping. México D.F.

Stephan, A. (2010). Cartels laws undermined: corruption, social norms, and collectivist business cultures. Journal of Law And Society, 37 (2), 345367.

Soto, R. (2013). Notas de Competencia. N. 2. Recuperado el 28 de mayo de 2015 de http://www.gomezacebo-pombo.com/media/k2/ attachments/notas-de-competencia-2-2013.pdf

Superintendencia de Industria y Comercio. (2013). Resolución 5413. Por la cual se ordena el archivo de una averiguación preliminar. Bogotá, D. C.: La Superintendencia.

Superintendencia de Industria y Comercio. (2004). Derecho de la competencia en Colombia y su interacción con los Tratados internacionales de libre comercio (diapositivas). Recuperado el 28 de mayo de 2016 de: http://www.sic.gov.co/recursos_user/documentos/ articulos/Derecho_competencia.pdf

Superintendencia de Industria y Comercio. (2013). Resolución 49141. Por medio de la cual se abre una investigación y se formula pliego de cargos. Bogotá, D.C.: La Superintendencia.

Superintendencia de Industria y Comercio. (2015). Resolución número 80847. Por la cual se impone sanción por cartelización empresarial. Bogotá, D.C.: La Superintendencia

Superintendencia de Industria y Comercio (2016) Resolución número 31739 del 26 de mayo de 2016. Por la cual se impone sanción por cartelización empresarial. Bogotá, D.C.: La Superintendencia.

Velandia, M. (2011). Derecho de la competencia y del consumo: competencia desleal; abuso de la posición de dominio; carteles restrictivos; actos 
restrictivos; integraciones económicas y protección al consumidor. $\left(2^{\mathrm{a}}\right.$ Ed.). Bogotá: Universidad Externado de Colombia. ISBN 978-958710-693-0.

Vitzilaio, L. (2011). Crisis cartels for better or for worse. Competition Policy International, 2, 4-7. 



\section{VI. \\ LA COLUSIÓN EN LA CONTRATACIÓN ESTATAL Y LA PROTECCIÓN DE LA COMPETENCIA: RETOS DEL NUEVO SISTEMA DE COMPRAS PÚBLICAS EN COLOMBIA \\ Leonardo Acevedo Valencia Leonardo av1@hotmail.com}



Resumen. El sistema de compras públicas enfrenta cambios normativos desde sus aspectos fundamentales, que pretenden modificar la esencia misma de los procedimientos de selección hacia un sistema de abastecimiento de estirpe más económica y de mercado. Esta dinámica, a su vez, se desarrolla de cara a las problemáticas que siempre ha enfrentado las relaciones surgidas en la contratación estatal, pero que difícilmente han podido ser superadas. Una de estas es la colusión, entendida como el acuerdo logrado entre dos o más personas en detrimento de un tercero. Dado que se trata de una figura que afecta el mercado y la competencia, su reglamentación se ha circunscrito a las disposiciones de estas especialidades jurídicas, desatendiéndose la aplicación de las normas especiales del Estatuto General de la Contratación de la Administración Pública (EGCAP), que pueden utilizarse para evitar y contrarrestar los efectos nocivos de este tipo de acuerdos ilegales.

Palabras clave. Colusión, sistema de compras públicas, caducidad, mecanismos, procesos de selección, oferta.

\section{Introducción}

Los análisis académicos y técnicos sobre la contratación estatal en Colombia, que pretenden proporcionar alternativas para enfrentar los problemas que sufre la sociedad en la materia, parecen insuficientes ante los incontables eventos de Corrupción registrados a lo largo de la geografía nacional. La constante preocupación será encontrar las estrategias concretas para contener o evitar las prácticas que generan este nocivo fenómeno. Una de las conductas más recurrentes que genera escenarios de corrupción es el acuerdo entre dos o más personas en detrimento de los intereses del Estado, esto es, el fenómeno de la colusión.

El presente análisis comprenderá una breve revisión de la normatividad que regula la protección de la competencia, así como las funciones que deben 
ejercer los servidores públicos encargados de la estructuración y dirección de los procesos de selección, y las actividades a su cargo, durante la ejecución del contrato estatal que incide en la protección de los intereses del Estado como consumidor. Por lo tanto, resulta necesario realizar un análisis sobre i) la normatividad en materia de defensa de la competencia que regula esta realidad en el país y su relación con las disposiciones aplicables a la contratación estatal en Colombia; así mismo, revisar ii) las normas especiales en materia de competencia creadas por la ley y el reglamento dentro del Estatuto General de Contratación de la Administración Pública y las disposiciones que lo complementan, analizando su suficiencia frente a los objetivos que persigue, así como iii) un estudio con perspectiva crítica del alcance práctico de las diferentes actuaciones que pueden adelantar los servidores públicos con el fin de evitar la materialización de prácticas colusorias que afecten el mercado de las compras públicas en consideración de los diferentes aspectos diferenciadores del sector propio al que acude el Estado para la satisfacción de sus necesidades, y, por último, iv) el análisis de determinados cursos de acción que podrían adoptarse con el fin de mejorar el control de las conductas que afectan la competencia en los procesos de selección de contratista.

El proyecto de reforma al sistema de compras públicas que pretende reemplazar al Estatuto General de Contratación de la Administración Pública (EGCAP) establecido en las leyes 80 de 1993 y 1150 de 2007, labor que deberá tener en cuenta la asignación de la competencia privativa atribuida a la Superintendencia de Industria y Comercio, para conocer de las investigaciones administrativas por infracción a las disposiciones sobre protección de la competencia que asignó Ley 1340 de 2009, produce en la práctica una limitación para el adecuado control y prevención frente a la ocurrencia de tales afrentas al mercado de las compras públicas, en razón a la insuficiente capacidad humana y técnica del ente de supervisión, inspección y vigilancia para atender las irregularidades presentadas en todo el territorio nacional.

El estudio de los aspectos señalados plantea más inquietudes de las respuestas que podrían obtenerse, en razón a la complejidad de las diferentes 
situaciones que usualmente se presentan, así como por la reducida capacidad institucional para el adecuado control de la problemática. Así, surgen innumerables dudas que merecen un serio estudio académico como ¿cuáles son las acciones concretas que pueden adelantarse para impedir la celebración de acuerdos específicos entre los oferentes en un proceso de selección de contratista, orientadas a la adjudicación del contrato en favor de uno de los proponentes en detrimento de los intereses públicos y los derechos de los demás participantes? ¿Cómo puede identificarse la conducta colusoria entre las diferentes actuaciones que se presentan típicamente en un proceso de selección de contratista? ¿Es posible, a la luz del ordenamiento colombiano, detener un proceso de selección de contratista ante el riesgo de producción de los efectos del acuerdo colusorio? Si ello es así, ¿Cuál es el trámite (administrativo o judicial) que debe adelantarse y quien está legitimado para promoverlo y qué entidad (además de la Superintendencia de Industria y Comercio) es competente para decidir e imponer las sanciones correspondientes? ¿Existe la posibilidad de cuestionar la legalidad del negocio jurídico estatal si se demuestra que se celebró como resultado de la materialización de un acto de colusión? ¿La presencia del acuerdo colusorio limita efectivamente la posibilidad de las entidades públicas de contar con un mayor número de ofertas para evaluar? Estas y otras inquietudes que nacen en virtud del análisis de las conductas que afectan la competencia en el mercado de compras públicas, deben ser estudiadas con óptica académica. pero con el firme propósito de presentar alternativas para mejorar la gestión de la administración pública. Pese a lo anterior, se estima conducente agrupar estar inquietudes en una única pregunta problema que permita el análisis de estas problemáticas, o en su defecto, definir el curso de acción para su análisis posterior.

En este contexto, se encuentra pertinente definir el problema de investigación de la siguiente forma ¿Cuáles son las acciones concretas definidas por el Estatuto General de Contratación de la Administración Pública, EGCAP, para evitar y contrarrestar la producción de conductas colusorias en los procesos de contratación estatal? 
El desarrollo de este sistema de compras estatal supone unas dinámicas especiales en el mercado, dada la interrelación sui generis que existe entre sus participantes, el segmento de la economía al que se acude, así como en cuanto a su identificación, calidad e interacción de los agentes que concurren para la presentación de las diferentes ofertas que participarán en el trámite para la selección de la mejor opción. En este contexto, se pretenden identificar con suficiencia las acciones concretas establecidas por la ley para evitar - no solo combatir o contrarrestar- las prácticas colusorias que restringen la competencia en el sistema de compras públicas, las cuales deben considerar las características especiales de los diferentes sistemas de abastecimiento establecidos para la satisfacción de las necesidades de las entidades públicas.

Punto aparte merece la consideración sobre la ocurrencia de estas prácticas restrictivas de la competencia en los regímenes exceptuados que se aplican en una gran proporción en el sector público, como quiera que por disposición legal existen entidades a las que se les ha permitido la aplicación de procedimientos especiales para la adquisición de sus bienes y servicios, y que, por lo tanto, no son destinatarios de las normas legales y reglamentarias que componen el Estatuto General de Contratación Pública. Esta realidad hace que en la práctica se evidencie la coexistencia de un régimen público con diferentes regímenes privados para la satisfacción de necesidades del Estado cuya satisfacción, pese a que se deben satisfacer con recursos públicos, permite la interacción de diferentes personas naturales y jurídicas en procesos de selección como oferentes en el mercado, sin el sometimiento a las reglas a las que están sometidas la mayoría de entidades estatales. Es pertinente aclarar que este análisis deberá abordarse en otra oportunidad, como quiera que es el interés del autor concentrarse en los procesos de abastecimiento cobijados por el Estatuto de Contratación Pública y el borrador del proyecto de ley diseñado por la Agencia para la Contratación Pública - Colombia Compra Eficiente, que pretende reemplazarlo.

Adicionalmente, es necesario aclarar que el presente análisis no se concentrará en ponderar el concepto mismo de la colusión, ni su ocurrencia en 
los procesos de contratación estatal, como tampoco el estudio de los efectos que causa este reprochable fenómeno, como quiera que la literatura nacional y extranjera ya se han preocupado por estudiar el fenómeno desde los citados ámbitos. Lo anterior, no obsta para recordar datos puntuales cuya precisión ayuda a dimensionar la importancia de la problemática.

El sistema de compras públicas en un Estado representa la mayor importancia para sociedad de que se trate, en la medida en que puede servir como herramienta idónea para i) satisfacer los fines del aparato estatal, así como ii) servir de herramienta para involucrar a los particulares en el adecuado funcionamiento de la gestión pública, al paso que sirve de mecanismo para la redistribución del ingreso entre los asociados. Por ello, la manera en que se elaboran, profieren y aplican las normas que lo regulan, debe caracterizarse por su imparcialidad, alto contenido ético y técnico, y la creación de un aparato estatal robusto que cuente con los mecanismos suficientes para poner en práctica sus disposiciones y lograr sus cometidos. Fundamento de esta importancia, es la participación que la contratación estatal tiene en el producto interno bruto de una nación. Piénsese por ejemplo que a través del mercado de las compras públicas se afecta más del $25 \%$ del producto interno bruto en Colombia (OECD, 2010). Esta participación es más reducida en otros países, pero no por ello deja de ser considerable. A título de ejemplo, en Francia la afectación de la contratación estatal en el PIB supera el $10 \%$. (Moore, 2012)

\section{El marco legal y reglamentario aplicable a las conductas colusorias en el mercado de compras públicas en Colombia}

El origen de la consagración legal de la colusión como práctica restrictiva de la competencia en Colombia puede remontarse hasta el artículo $1^{\circ}$ de la Ley 155 de 1959, cuyo texto original fue modificado por el $1^{\circ}$ del Decreto 3307 de 1963, al prohibirse 
(---) los acuerdos o convenios (sic) que directa o indirectamente tengan por objeto limitar la producción, abastecimiento, distribución o consumo de materias primas, productos, mercancías o servicios nacionales o extranjeros, y en general, toda clase de prácticas, procedimientos o sistemas tendientes a limitar la libre competencia y a mantener o determinar precios inequitativos. (Decreto 3307 de 1963 [con fuerza de ley]. Por el cual se toman medidas sobre monopolios y precios. Diciembre 30 de 1963 . DO. $N^{\circ}$ 31265)

La norma citada, debe aplicarse en concordancia con el artículo 47 del Decreto 2153 de 1992 que enuncia las conductas que pueden considerarse como restrictivas de la competencia, indicando en su numeral 9 que constituyen este tipo de acciones "Los que tengan por objeto la colusión en las licitaciones o concursos o los que tengan como efecto la distribución de adjudicaciones de contratos, distribución de concursos o fijación de términos de las propuestas”, definiendo en concreto el campo de acción de la figura bajo estudio.

Adicionalmente, la Ley 1340 de 2009, por la cual se dictan normas en materia de protección de la competencia, establece el procedimiento administrativo que debe seguirse a fin de declarar las responsabilidades frente a la ocurrencia de conductas que restrinjan la libre competencia, como la colusión, asignando la competencia privativa a la Superintendencia de Industria y Comercio para adelantarlas. Así mismo, estableció un régimen de beneficios para incentivar a aquellos involucrados en estas prácticas a delatar a otros intervinientes a cambio de la obtención de beneficios como la exención en la imposición de la sanción o una disminución de ella, dependiendo de la "de la calidad y utilidad de la información que se suministre" (Numeral $2^{\circ}$, artículo $4^{\circ}$ de la Ley 1340 de 2009. Por medio de la cual se dictan normas en materia de protección de la competencia. Julio 24 de 2009. DO. N47420)

En este sentido, y teniendo en cuenta que las conductas señaladas en las normas citadas pueden lograrse con el fin de producir un daño a un tercero 
(colusión), resulta claro que sus efectos se producen tanto en los mercados privados como en los públicos, creados en razón de la apertura y conclusión de los procesos de selección de contratista adelantados por las entidades públicas para la satisfacción de sus necesidades. Se afirma que en el caso de la contratación pública, el mercado se “crea”, en razón de las características que lo estructuran, cada vez que una institución estatal manifiesta su interés de convocar al público a presentar ofertas para la venta de bienes o la prestación de servicios que deberían satisfacer sus necesidades. (Ossa, 2014)

En este punto, resulta relevante revisar las características que rodean el mercado que crea el Estado en cada oportunidad en que convoca al público con el fin de satisfacer adecuadamente las necesidades que ha identificado, cuyo bienestar permite el logro de los fines esenciales del Estado definidos en la Constitución. El mercado de las compras públicas es un espacio sui generis, como quiera que depende de las especiales condiciones del bien o servicio identificado en la fase de planeación de la etapa precontractual, así como por la forma en que se garantice la publicidad de la convocatoria, como del número de ofertas que se hayan presentado y que reúnan las condiciones mínimas para ser consideradas para la etapa de evaluación; adicionalmente, el presupuesto oficial establecido por la entidad puede limitar el deseo de ciertos actores de participar o no en el proceso de selección correspondiente. Por último, la consideración sobre el alcance de los fines sociales del Estado incide en los criterios que el Estado consumidor valora para la selección objetiva de la oferta más favorable para el cumplimento de sus cometidos.

Ahora bien, el análisis de las normas que regulan la colusión tanto en las normas de protección de la competencia, como en las normas que rigen la contratación estatal, es pertinente indicar que en las reglas específicas que regulan los procedimientos establecidos para el perfeccionamiento, ejecución y liquidación de los contratos estatales, las disposiciones que permiten la identificación y prevención de la ocurrencia de conductas colusorias no se han diseñado mediante una técnica legislativa sistemática que permita maximizar su eficacia, en especial, por la ausencia de una definición legal específica, así 
como por la omisión en el diseño de procedimientos claros y la asignación de competencias específicas a las autoridades públicas.

En primer término, es necesario afirmar que la Ley 80 de 1993 no se preocupó por regular de manera suficiente los escenarios relacionados con la configuración de acuerdos celebrados entre los oferentes en un proceso de contratación, en detrimento de los intereses estatales; en consecuencia, no estableció herramientas y procedimientos concretos para el efecto, dejando así desarmada a la Administración Pública para combatir este fenómeno.

Las figuras reguladas por la Ley 80 de 1993 relacionadas con la colusión se limitan a: i) la regulación en el régimen de inhabilidades de la prohibición de presentar ofertas en un mismo proceso de contratación por parte de cónyuges o compañeros permanentes, o familiares y personas dentro de determinados grados de consanguinidad y afinidad, así como por personas jurídicas cuyos socios o representantes legales se encuentren relacionados por los mismos lazos personales o de sanguinidad o afinidad; ii) la facultad para declarar desierto el proceso de licitación cuando se advierta la violación del principio de selección objetiva; iii) el deber de repetir contra los servidores públicos, oferentes y/o terceros intervinientes que con sus conductas hayan ocasionado perjuicios como consecuencia de la actividad contractual; iv) la declaratoria de caducidad del contrato por la ocurrencia de pactos o acuerdos prohibidos; y vi) la consagración de un régimen de responsabilidad genérico sobre los servidores públicos que hayan actuado de manera negligente en la estructuración de los documentos previos cuando su contenido oscuro o deficiente cause efectos que alteren el proceso de contratación, así como para los contratistas que hubieren formulado ofertas con precios artificialmente bajos con el fin de lograr la adjudicación del contrato.

Pese a lo anterior, se estima pertinente señalar los cursos de acción específicos que a la luz del Estatuto General de Contratación de la Administración Pública, EGCAP, pueden adelantarse con el fin de evitar o contrarrestar las conductas relacionadas con la colusión en los procesos de contratación 
pública. Para ello, se relacionarán y comentarán los mecanismos establecidos en la ley para evitar la colusión, así como las medidas o herramientas jurídicas que se pueden utilizar para corregir los efectos de las prácticas colusorias una vez perfeccionadas.

\section{Mecanismos establecidos en el EGCAP para evitar las prácticas colusorias}

\section{I Aplicación del Régimen de inhabilidades}

Los mecanismos o herramientas establecidos en las disposiciones que regulan la contratación estatal, como ya se dijo, se han limitado a regular diferentes prohibiciones en el régimen de inhabilidades. Como es bien sabido, el régimen de inhabilidades reúne taxativamente las circunstancias que al presentarse, impiden a una persona presentar una oferta dentro de un proceso de selección, y eventualmente, celebrar el contrato con la entidad pública correspondiente. Estas causales se han estructurado con el fin de garantizar la prevalencia del principio constitucional de moralidad ${ }^{1}$, al paso que permiten el desarrollo de una gestión pública apegada a los parámetros de la moralidad administrativa, pues desea evitarse que por diferentes circunstancias de orden jurídico o fáctico, la celebración y desarrollo de un contrato viole el principio superior de selección objetiva. En otras palabras, la selección de la mejor oferta y la consecuente celebración del contrato estatal deben estar precedidas por la constatación que adelante la entidad estatal de unas condiciones de orden ético y jurídico que hagan transparente y objetiva la selección del contratista. Así, el

\footnotetext{
1. La moralidad como principio rector del ejercicio de la función administrativa, dentro de la cual se ubica la gestión contractual de la administración, tiene su consagración constitucional en el artículo 209 de la Constitución Política de 1991. Lo relevante de precisarlo no es hacer énfasis en la referencia normativa, sino en la importancia que implica el que el constituyente haya deseado consagrarlo como, i) principio y ii) con nivel de norma superior. Al hacerlo, quiso el constituyente definir un plan de acción que debía ser desarrollado por las demás normas del ordenamiento, con el fin de lograr su interiorización con vocación de permanencia en la sociedad.
} 
régimen de inhabilidades no se preocupa por la idoneidad del oferente, ni de la calidad de la oferta presentada, sino por la entereza moral del agente, del ejercicio de sus conductas ajeno a circunstancias que puedan influirlas negativamente, así como de la capacidad jurídica libre de elementos que violen su libre arbitrio.

En este sentido, conviene recordar en palabras del Honorable Consejo de Estado, la importancia y fundamento superior de la existencia del régimen de inhabilidades e incompatibilidades al sostener que:

Adicionalmente, toda vez que la Jurisprudencia Constitucional se ha referido a la protección del interés general como causa que legitima la estructuración legal de las incompatibilidades e inhabilidades, se puede precisar que la regulación de sus causales para contratar con el Estado debe orientarse por el Principio de Moralidad que obviamente -como es propio de todos los principios de la Función Administrativa- se despliega ordenado con base en la protección prevalente del interés general y, por ello, se entiende que la potestad de configuración legislativa en materia de incompatibilidades e inhabilidades para contratar con el Estado, puede concretarse a través de una regla de carácter excluyente para determinados potenciales contratistas, la cual se impone entonces por razón de ese fin de interés general como regla legal prevalente, esto es que puede ser impuestas sobre el derecho individual a contratar con el Estado. (Consejo de Estado, 2013)

En este sentido, vale la pena señalar dos causales de inhabilidad para presentar oferta y contratar con el Estado, cuyo sentido y alcance podrían evitar la configuración de conductas colusorias en los procesos de selección dispuestos por las entidades públicas. A continuación se citarán dichas disposiciones, con el fin de comentar su alcance en el contexto que se ha establecido en el presente análisis. 
En primer término se encuentra el literal g) del artículo 8 de la Ley 80 de 1993 que prohíbe presentar ofertas en los procesos de selección, y celebrar el correspondiente contrato, a “Quienes sean cónyuges o compañeros permanentes y quienes se encuentren dentro del segundo grado de consanguinidad o segundo de afinidad con cualquier otra persona que formalmente haya presentado propuesta para una misma licitación”.

La prohibición citada pretende evitar que dos o más personas que se encuentran en una relación de proximidad en razón a su vínculo conyugal, personal o familiar, celebren un acuerdo para la presentación de ofertas en el mismo proceso de selección, pues, una regla de la experiencia indica que las personas que comparten un mismo origen personal o familiar usualmente desarrollan proyectos en común, o informan a su círculo de influencia más próximo de la posibilidad de ejecutar tales actividades, sobre todo en lo que guarda relación con la probabilidad de celebrar un contrato con la Administración. Dicha eventualidad podría llevar también a estas personas a coludir para aumentar la probabilidad de lograr la adjudicación del negocio jurídico correspondiente. Ahora bien, la importancia de referir la disposición en comento es la de considerar su eficacia para prevenir la ocurrencia de la conducta ilegal. El efecto útil de las normas no se mide por su consagración expresa sino por su aptitud para condicionar efectivamente el comportamiento de sus destinatarios.

En este punto, el interrogante inmediato que se plantea es ¿cómo puede establecerse si entre los diferentes oferentes existe algún tipo de relación de las prohibidas por el régimen de inhabilidades? Para responderlo, debe considerarse en primer lugar que el funcionario que instruye el proceso de selección debe partir de la buena fe como principio constitucional que guía sus actuaciones ante los particulares. Dicho funcionario no podría exigir más requisitos de los previamente establecidos en la norma del proceso consagrada en los correspondientes pliegos. Sin embargo, está facultado para revisar el cumplimiento de los requisitos mínimos que permiten establecer si los diferentes proponentes están habilitados para continuar en el trámite antes de ser 
evaluadas sus ofertas. En este momento, podría establecer si de los documentos de la oferta puede concluirse razonablemente la proximidad familiar o personal entre algunos de los proponentes. Adicionalmente, los demás proponentes, quienes generalmente conocen a sus competidores en el mercado, podrían poner en evidencia dicha situación a la administración, siempre que les sea permitido acceder a la información básica contenida en la oferta; se trata de un tipo de "veeduría competitiva" permitida a los diferentes agentes del proceso siempre que se ejerza con la intención de colaborar en el adecuado alcance de los fines sociales del Estado que pretenden satisfacerse con el proceso de contratación.

En segundo lugar, se encuentra el literal h) del artículo 8 de la Ley 80 de 1993, según el cual

Las sociedades distintas de las anónimas abiertas, en las cuales el representante legal o cualquiera de sus socios tenga parentesco en segundo grado de consanguinidad o segundo de afinidad con el representante legal o con cualquiera de los socios de una sociedad que formalmente haya presentado propuesta, para una misma licitación.

Esta causal pretende evitar que quienes se encuentren en las relaciones personales o de parentesco establecidas en el literal g) ya citado, traten de burlar dicha prohibición al constituir personas jurídicas para poder presentar oferta en el mismo proceso de selección de contratista. En este punto, las consideraciones sobre los cursos de acción que pueden adelantar los agentes de la administración, considerados en el punto anterior, son aplicables en esta situación, pero demandarán de una labor más juiciosa en la medida en que deben establecer con objetividad quienes tienen participación en las diferentes personas morales que han presentado oferta dentro del correspondiente proceso de selección.

Adicionalmente, vale la pena considerar que la consecuencia que ha consagrado el ordenamiento para la celebración de un contrato estatal con 
una persona incursa en estas causales de inhabilidad, es la nulidad del correspondiente negocio jurídico. Esta sanción, aunque severa, no constituye una solución eficaz para evitar la configuración de la conducta colusoria, ni para prevenir los efectos nocivos que se causan tanto al mercado como a los intereses público, como quiera que su declaración solo procede mediante sentencia emitida por una autoridad judicial de la jurisdicción contencioso administrativa, lo que implica que el trámite del proceso judicial correspondiente, considerando sus diferentes instancias, puede tomarse varios años, y la decisión seguramente adquirirá firmeza mucho tiempo después de que las partes hayan finiquitado la relación contractual. Por ello, no se puede considerar como un mecanismo eficaz para evitar o contrarrestar la práctica colusoria que pudo configurarse mediante la violación al régimen de inhabilidades.

Con todo, y bajo la hipótesis de haberse podido establecer durante el proceso de selección que algunos de los oferentes se encuentran dentro de las causales del régimen de inhabilidades citadas, resulta pertinente indicar que el medio de acción correspondiente es la exclusión del proceso de los diferentes involucrados mediante la expedición del acto administrativo correspondiente, siempre que se permita a los afectados previamente ejercer sus derechos de defensa y contradicción. Este trámite debe haberse previsto en los pliegos, y su desarrollo debe considerar también los términos del proceso de selección en general, para que todas las actuaciones administrativas que deban adelantarse no afecten negativamente el cronograma establecido.

\subsection{La exclusión de los oferentes coludidos o la declaratoria de desierta de los procesos de selección con ofertas producidas por acuerdos colusorios}

En tercer lugar dentro de la enumeración de los mecanismos que pueden utilizarse para prevenir la ocurrencia de los efectos de conductas colusorias en los procesos de selección de contratista, debe señalarse la facultad de la Administración de i) excluir mediante acto administrativo a los oferentes que 
han celebrado un acuerdo colusorio con el fin de asegurar la adjudicación del contrato estatal, en razón de lo establecido en el numeral $6^{\circ}$ del artículo 26 de la Ley 80 al señalarse que "Los contratistas responderán cuando formulen propuestas en las que se fijen condiciones económicas y de contratación artificialmente bajas con el propósito de obtener la adjudicación del contrato”, o ii) declarar desierto el proceso de convocatoria pública por violación del principio de selección objetiva, en atención a lo establecido en el numeral 18 del artículo 25 de la Ley 80 de 1993 que dispone:

La declaratoria de desierta de la licitación únicamente procederá por motivos o causas que impidan la escogencia objetiva y se declarará en acto administrativo en el que se señalarán en forma expresa y detallada las razones que han conducido a esa decisión.

La declaratoria de desierta de un proceso de selección es una facultad otorgada a la Administración para manifestar expresamente la imposibilidad de escoger una oferta para satisfacer la necesidad previamente identificada, en razón a la presencia de circunstancias que impidan la selección objetiva de tales propuestas, o en ausencia total de estas. En la hipótesis que se analiza, la declaratoria de desierta no se realiza por ausencia de ofertas, sino porque de las presentadas, existen serias dudas sobre la existencia de un acuerdo colusorio que pretende direccionar la selección de una de tales alternativas, con el fin de lograr la adjudicación del contrato. Así, la configuración del acuerdo colusorio impide a la Administración seleccionar la oferta que mejor satisface la necesidad de la entidad, como quiera que la propuesta económica presentada demuestra una realidad amañada o limitada a la entidad estatal, que la llevarán a otorgar una calificación inexacta al oferente que pone a consideración un contenido económico que no obedece a las condiciones reales del mercado.

Si del número de ofertas presentadas puede evidenciarse que algunas de ellas contienen elementos de los cuales puede concluirse la celebración de un acuerdo colusorio, la Administración cuenta con la facultad de excluir del 
proceso correspondiente a los oferentes involucrados. Esta decisión, sin embargo, no podría adoptarse por la autoridad administrativa basada en la producción de la conducta colusoria per se, pues la legislación no ha facultado expresamente a las entidades administrativas para emitir esta declaración e imponer como consecuencia la sanción de exclusión al oferente coludido. Lo que se afirma es que, comprobados los elementos que podrían configurar el acuerdo ilegal, la administración tendría la facultad de declarar que la participación de los oferentes involucrados puede producir la afectación al principio de selección objetiva de la mejor oferta y, como consecuencia, excluir dicha propuesta mediante acto administrativo a los intervinientes del aparente acuerdo colusorio en el proceso de selección correspondiente. Esta decisión, deberá adoptarse previa la aplicación de las etapas del procedimiento administrativo sancionatorio consagrado en la Ley 1437 de 2011, Código de Procedimiento Administrativo y de lo Contencioso Administrativo, como quiera que no está regulado un trámite especial que pueda aplicarse en esta situación particular Dado que esta manifestación implica una sanción concreta como lo es la exclusión del oferente del proceso, deben respetarse los derechos de defensa, debido proceso y contradicción.

En este contexto, resulta pertinente insistir en que la demostración de la conducta colusoria no es el fundamento de la exclusión. Bastaría con la demostración de un hecho indicador que lleve a pensar razonablemente la posible existencia de la colusión, para estructurar el fundamento suficiente de la exclusión de la oferta. Lo anterior, implica la demostración de algunas de las siguientes situaciones: i) configuración de ofertas demasiado altas o bajas por dos o más proponentes; ii) el direccionamiento de ofertas mediante la presentación y posterior retiro de una o más ofertas; iii) la presentación de ofertas por personas naturales o jurídicas que han participado en procesos similares con anterioridad en la misma entidad, pero con condiciones que permiten a otros oferentes una mejor calificación, estableciéndose un patrón de rotación. El funcionario instructor debe valerse de estructuras probatorias propias de la prueba indiciaria, como quiera que la demostración de los anteriores hechos indicadores, resulte necesaria para establecer la probabilidad de la conducta colusoria, pero no su ocurrencia. Lo anterior, en razón a que la entidad que 
desarrolla el proceso de selección, no es competente para declarar la responsabilidad en esta materia, así como tampoco lo es para imponer las sanciones pecuniarias correspondientes.

\section{Mecanismos para contrarrestar los efectos de las prácticas colusorias establecidos en el EGCAP}

\section{I. La acción de repetición}

Además de las acciones que pueden adelantar las autoridades administrativas para prevenir la producción de efectos de los acuerdos colusorios en los procesos de contratación estatal sometidos al EGAP, en conveniente revisar los cursos de acción que pueden adelantarse para contrarrestar la producción de tales consecuencias, una vez perfeccionada la conducta y celebrado el contrato con la Administración. En las siguientes hipótesis, la administración advierte la colusión después de adjudicado el contrato correspondiente y su preocupación se centra en contener o contrarrestar el daño sufrido como consecuencia del acuerdo ilegal.

En primer lugar, debe señalarse la posibilidad de iniciar la acción de repetición consagrada en el numeral $7^{\circ}$ del artículo 4 de la Ley 80 de 1993 al disponer que "Sin perjuicio del llamamiento en garantía, (las entidades estatales) repetirán contra los servidores públicos, contra el contratista o los terceros responsables, según el caso, por las indemnizaciones que deban pagar como consecuencia de la actividad contractual”.

En esta hipótesis, es necesario demostrar que la celebración del acuerdo colusorio ocasionó un perjuicio a los intereses del Estado o de los demás oferentes, quienes pudieron obtener un mejor precio para la adquisición del bien o servicio, así como un beneficio concreto que no se recibió como consecuencia de la adjudicación del contrato a un oferente que distorsionó el contenido de su propuesta económica. Por ello, la condición para su procedencia es el 
inicio de un medio de control concreto contra la administración y el oferente de quien se presume participación en la colusión.

Adicionalmente, esta herramienta, supone la participación de uno o varios servidores públicos en la configuración del acuerdo ilegal, al intercambiar información con los oferentes, de tal manera que puedan anticipar cómo serán valorados determinados ítems en las propuestas a presentar, o ya, al diseñar condiciones de difícil cumplimiento relacionadas con la capacidad para contratar, la experiencia, precios mucho más bajos de los ofrecidos en el mercado para el bien o servicio correspondiente, capacidad instalada, entre otros aspectos, siempre que dicha participación sirva de causa necesaria para la producción de un daño antijurídico. Así mismo, puede presentarse esta situación, si la desatención grave por parte de un funcionario estatal en la estructuración del proceso de selección, la evaluación de las ofertas y la adjudicación del contrato, causa un daño indemnizable a cargo de la administración. Esto puede suceder por ejemplo, en caso de demostrarse que el servidor público no cumplió su deber de elaborar un estudio de mercado con la información suficiente que permitirá establecer que una o varias propuestas contenían precios artificiales, o muy bajos o muy altos, que incidieron directamente en la adjudicación del contrato.

Resulta necesario comentar que la posición descrita, encuentra también su fundamento legal en la consagración de los mecanismos a lugar para el cumplimiento del principio de responsabilidad establecidos en el artículo 26 de la Ley 80 de 1993 , numerales $2^{\circ}$ y $3^{\circ}$, que disponen:

$2^{\circ}$. Los servidores públicos responderán por sus actuaciones y omisiones antijurídicas y deberán indemnizar los daños que se causen por razón de ellas;

$3^{\circ}(. .$.$) cuando los pliegos de condiciones hayan sido elabora-$ dos en forma incompleta, ambigua o confusa que conduzcan a interpretaciones o decisiones de carácter subjetivo por parte de aquellos. 


\subsection{La Declaratoria de Caducidad del Contrato}

Otra alternativa para contrarrestar la producción de los efectos negativos de acuerdos colusorios en la contratación estatal, es el ejercicio de la facultad establecida para la administración de la declaratoria de caducidad del contrato estatal, en atención a lo establecido en el inciso final del artículo $5^{\circ}$ de la Ley 80 de 1993 que dispone que “(...) la celebración de los pactos o acuerdos prohibidos, dará lugar a la declaratoria de caducidad del contrato”.

Obsérvese que por definición, la colusión es un acuerdo o pacto ilegal que se celebra con el fin de afectar a terceros (en este caso, el Estado) mediante el direccionamiento para beneficiarse con la adjudicación del contrato estatal. De esta forma, tras comprobarse la celebración de uno de tales acuerdos, resulta procedente que la administración declare expresamente la caducidad correspondiente, lo que además permite la imposición de la sanción al contratista responsable de inhabilidad por el tiempo estipulado en la ley, circunstancias que además genera la afectación de los demás negocios jurídicos que haya suscrito con el Estado.

Para la configuración de esta posibilidad, resulta necesario el pronunciamiento previo por parte de la autoridad nacional de la competencia, que para el caso colombiano es la Superintendencia de Industria y Comercio, sobre la responsabilidad del contratista en la celebración del acuerdo colusorio. Esta decisión, permitirá a la entidad contratante iniciar el proceso administrativo correspondiente para la declaratoria de caducidad, con aplicación del trámite establecido en la Ley 1474 de 2011, aun sin que existiese una consagración expresa en el articulado del contrato.

\section{La colusión y el proyecto de reforma al EGCAP presenta- do por Colombia Compra Eficiente}

Mediante la elaboración de un anteproyecto de ley cuyo objeto único es la derogatoria del EGCAP (Ley 80 de 1993), el Gobierno Nacional, a través de 
la Agencia Nacional para la Contratación Pública- Colombia Compra Eficiente, pretende poner a tono la legislación nacional en la materia con los estándares internacionales que permitan facilitar el ingreso del país a la OCDE. (OECD, 2010)

Dentro de los múltiples cambios propuestos por la agencia estatal en el proyecto, está el del imprimir un cambio en la concepción de los procesos para la contratación con el Estado, ya que hasta ahora se ha pensado en un cuerpo normativo orientado a la reglamentación de procedimientos de selección de contratistas. El proyecto de legislación pretende cambiar esa visión a la de un sistema de abastecimiento integral que conceda mayor margen de movilidad a las entidades públicas para la satisfacción de sus necesidades.

Por ello, se observa con preocupación el que se esté desaprovechando la oportunidad para que el legislador reglamente al detalle sobre los mecanismos, procedimientos y entidades competentes para prevenir y combatir el fenómeno de la colusión, sobre todo si se considera el deseo de Colombia Compra Eficiente por separar los asuntos relacionados con la contratación pública del ámbito de influencia del derecho administrativo, dejando el proceso de abastecimiento a las reglas del derecho privado.

En este sentido, el proyecto se limita a reiterar las limitaciones atinentes a los regímenes de inhabilidades e incompatibilidades pero cambiando la denominación a la expresión genérica de "prohibiciones", conservando las relativas a la cercanía personal o familiar, por lo que en ese punto el cambio no sería relevante, y se limita a lo ya expuesto, adicionando una prohibición para las personas jurídicas, cuyos representantes legales o miembros de junta directiva hayan sido condenados por el delito de colusión, prohibición que pretende extenderse por el término de 20 años, contados a partir de la ejecutoria de la correspondiente sentencia, pero dejando de lado las sanciones impuestas por pronunciamientos en procesos administrativos adelantados por la Superintendencia de Industria y Comercio. 
Por otro lado, resulta también inquietante el cambio que pretende hacerse a las modalidades de selección establecidas desde la Ley 80 de 1993, afianzado con la Ley 1150 de 2007, pues se crea un procedimiento que puede prestarse para la celebración de acuerdos en detrimento de los intereses del Estado. Así, en el numeral 2 del artículo 51 del proyecto, establece la posibilidad de realizar convocatorias limitadas con un sistema de precalificación, con el siguiente alcance:

Competencia restringida con precalificación. Las Entidades Estatales pueden restringir la competencia para seleccionar el proveedor a un grupo de precalificados cuando el bien, obra o servicio requiere de condiciones técnicas, financieras, administrativas o de experiencia particulares. Para el efecto, la Entidad Estatal debe señalar la forma y oportunidad para que los potenciales proveedores acrediten las condiciones especiales requeridas, verificar tales condiciones y conformar la lista de precalificados, quienes serán los únicos que pueden presentar oferta.

Tal como puede apreciarse, las expresiones "competencia restringida" y "grupo de precalificados" permiten pensar en que bien puede la entidad estatal incluir en los documentos previos condiciones en virtud de las cuales la participación en principio abierta al público, termine limitándose a un reducido grupo de interesados, mandato que implica a su vez la limitación de la competencia en el sector del mercado correspondiente. Lo anterior se evidencia también en la modalidad de selección establecida en el numeral 3 del citado artículo 51 del proyecto que establece:

Competencia restringida con invitación y posterior negociación. Las Entidades Estatales pueden seleccionar a sus proveedores a través de invitaciones al público en general y fases sucesivas de negociación en las cuales deben cumplir los principios establecidos en el artículo 7 de la presente ley en los siguientes casos:” (a) La especificidad y complejidad del bien, obra o servicio no 
permiten definir con claridad y precisión los aspectos técnicos y financieros de la contratación.; (b) El objeto de la contratación no es producido masivamente y requiere investigación y desarrollo para que la contratación sea eficaz.; (c) Es necesario compatibilizar el bien, obra o servicio objeto del Contrato con otros bienes, obras o servicios de la Entidad Estatal.; (d) La compra de inmuebles para el funcionamiento y operación de las instalaciones de la Entidad Estatal.; y, (e) El arrendamiento de inmuebles para el funcionamiento y operación de las instalaciones de la Entidad Estatal.

Como puede observarse, la posibilidad de negociar las condiciones de un contrato estatal con un grupo reducido de oferentes podría limitar drásticamente las condiciones de igualdad en el mercado para los participantes, e incluso, podría afectar negativamente la manera en que se afecta el erario, pues la negociación no se concibe como herramienta orientada exclusivamente al uso eficiente del erario.

Adicionalmente, el proyecto no contempla la posibilidad de rechazar una oferta por haberse demostrado un hecho indicador de una posible conducta colusoria, pues al regular las causales taxativas para el rechazo de ofertas en el artículo 58 del proyecto, dispuso:

Artículo 58. Rechazo de ofertas.

Las Entidades Estatales deben rechazar las ofertas en los siguientes casos:

1. Cuando la oferta es incompleta porque no tiene los elementos esenciales del negocio jurídico.

2. Las ofertas presentadas por quien es objeto de una prohibición establecida en los artículos 21 a 25 de la presente ley.

3. Las ofertas anormalmente bajas de acuerdo con el artículo 57 de la presente ley. 
Tal como puede apreciarse, son limitadas las herramientas jurídicas que pretenden crearse en el proyecto de reforma al Estatuto General de Contratación de la Administración Pública, para evitar o contrarrestar la colusión. Este panorama, aunado a la limitada ejecutividad y efectividad de las herramientas vigentes en la materia, perpetúan en cabeza de la Superintendencia de Industria y Comercio la competencia exclusiva para adelantar procedimientos orientados a sancionar (no prevenir) las conductas colusorias.

Para ello, hace falta, además de un mayor compromiso institucional frente a la creación de normas que definan una política pública clara y coherente, firmeza en el ejercicio de las potestades administrativas de los servidores que diseñan y sustancian los procesos de selección de contratistas, para que tengan la decisión de adelantar acciones concretas orientadas a proteger los intereses superiores del Estado, los cuales siempre son los más afectados con la inadecuada gestión contractual de la Administración. 


\section{Conclusiones}

La posición institucional frente a las conductas colusorias en la gestión contractual del Estado es principalmente reactiva, por cuanto, pese a establecer la prohibición de determinadas situaciones en los regímenes de inhabilidades, los procedimientos administrativos que se adelantan inician después de la configuración de su conducta, a lo que debe agregarse que la declaración de responsabilidad se apoya en muchos eventos en la colaboración que presten los involucrados en el acuerdo colusorio bajo el esquema de beneficios establecidos en la legislación. La realidad nacional, ampliamente dominada por fenómenos de corrupción, claman por la construcción de nuevas visiones que impidan de manera eficaz el fenómeno, más allá de limitarse a combatirlo.

Adicionalmente, la ausencia de un plan de formación para los funcionarios encargados de diseñar los procedimientos de selección de contratistas a la luz del EGCAP impide la identificación de las prácticas restrictivas de la competencia como la colusión. En este sentido, las administraciones públicas, tanto del orden nacional como del nivel territorial, deberían propender por la adecuada capacitación de sus servidores, mediante planes de aprendizaje regulares y con visión teórico - práctica, cuyo desarrollo les permita anticipar la ocurrencia de estas actuaciones, para adoptar las decisiones administrativas oportunas, en aplicación de las facultades ya existentes en el ordenamiento jurídico.

Por último, la falta de capacidad institucional de los organismos de control, así como la concepción actual de su participación en los procesos de gestión contractual del Estado, los pone en una posición limitada frente a la configuración de conductas colusorias en los procedimientos de selección de contratistas. En este sentido, bien podría pensarse en la creación de estrategias de descentralización por colaboración en las cuales observatorios y áreas técnicas de investigación de Instituciones de Educación Superior, IES, puedan realizar estudios especializados y participación activa en los procesos de selección de contratista, identificando riesgos y enviando aler- 
tas a las autoridades competentes, a fin de que se tomen medidas oportunas que conserven efectivamente el erario. Ello, permitiría a las IES cumplir con dos de sus funciones sustantivas esenciales como lo son la investigación y la proyección social, participando decididamente en la transformación de la sociedad colombiana. 


\section{Referencias}

Almanza, C. P. (2012). La libertad de competencia en los procesos de selección objetiva. Bogotá: Universidad Externado de Colombia.

Camacho, E. M. (2015). MANUAL DE CONTRATACIÓN DE LA ADMINISTRACIÓN PÚBLICA:REFORMA DE LA LEY 80 DE 1993. Bogotá: Universidad Externado de Colombia.

Comercio, S. D. (2010). Guía Práctica para Combatir la Colusión en las Licitaciones. Bogotá: Superintendencia de Industria y Comercio.

Consejo de Estado. (2013). Ciarquelet Ltda. Vs. Distrito Capital Departamento Administrativo de Acción Comunal Distrital y Consorcio Comunidad y Construcción. Sentencia Sección Tercera, Subsección A, Sala de lo Contencioso Administrativo, 34.

Development, O.f.-o. (2010). ROUNDTABLE ON COLLUSION AND CORRUPTION IN PUBLIC PROCUREMENT. París: OCDE. Galvis-Quintero, D. (2016). LA COLUSIÓN COMO UNA PRÁCTICA RESTRICTIVA DE LA COMPETENCIA QUE AFECTA GRAVEMENTE LOS PROCESOS DE SELECCIÓN DE CONTRATISTAS. Vniversitas, volumen (número),133-196.

Gómez-Lee, I. D. (2010). Contratación visible, Manual para un buen control de recursos en la contratación pública. Bogotá: Auditoría General de la República - Instituto de Estudios.

Moore, J. (2012). Cartels Facing Competition in Public Procurement: An Empirical Analysis. Ciudad: Institut d'Administration des Entreprises.

OECD, T. O. (2010). Collusion and Corruption in Public Procurement. París: OECD.

OCDE. (2013). Combate a la Colusión en los Procesos de Contratación Pública en México. París: OCDE.

Ossa, C. E. (2014). Tratamiento de la colusión en la contratación pública: 
una visión del caso colombiano. Revista de Derecho, volumen (número), $\mathrm{xx}-\mathrm{xx}$

Peñalosa, E. J. (2010). Novedades de la Ley 1340 de 2009 para el régimen de protección de la competencia. Revista Contexto, volumen (número), $\mathrm{xx}-\mathrm{xx}$.

Peñalosa, E. J., \& Pabón Almanza, C. (2012). Colusión en licitaciones El caso paradigmático para las entidades públicas. Revista de Derecho y Economía, volumen (número), 9-32.

Quijano, J. P. (1999). Manual de Derecho Probatorio. Bogotá: Ediciones Librería del Profesional.

Santofimio, J. O., \& Benavides, J. L. (2009). Contratación estatal. Estudios sobre la reforma del Estatuto Contractual. Ley 1150 de 2007. Bogotá: Universidad Externado de Colombia.

Velandia, M. (2011). Derecho de la competencia y del consumo . Bogotá: Universidad Externado de Colombia. 
CONCLUSIONES 

n una perspectiva normativa se presentaron los antecedentes del actual Estatuto de Protección al Consumidor, observando que ha sido latente la preocupación del legislativo por regular lo concerniente a esta actividad, hecho que se materializó en la Ley 73 (1981), denominada en su momento como Ley del Consumo.

En concordancia con lo arriba señalado, los Decretos 1441 y 3466 (1982) se encargaron del régimen de control y vigilancia de las ligas y asociaciones de consumidores, como también de los bienes y servicios ofrecidos en sus caracteres de idoneidad, calidad, marcas, leyendas, propagandas y la fijación pública de precios de bienes y servicios, la responsabilidad de los productores, expendedores y proveedores.

No obstante, las trasformaciones sociales y jurídicas sumadas a los cambios constitucionales, conllevaron a redefinir el tema del consumo, otorgando una protección especial al consumidor; en una interpretación sistemática de la Ley 1480 de 2011, fruto del proyecto de Ley 252 de 2011 senado, 089 de 2010 cámara de representantes, se estimó: “(...) ser ajeno a los cambios ha intentado establecer entre consumidores y proveedores relaciones más equilibradas, generar un marco de respeto mutuo, aumen- 
tar el crecimiento del mercado y beneficiar con su actividad y desarrollo a la comunidad".

El garantismo, bandera del Estado Colombiano cobija también las relaciones de consumo y como se expresó en renglones anteriores para proteger al consumidor, estableciendo un marco de responsabilidades a cargo del productor o distribuidor de bienes y servicios, contenida en el artículo 20 de la Lay 1480. Esta normativa establece la responsabilidad solidaria entre el productor y el expendedor por los daños causados con motivo de los defectos que tengan los productos comercializados, imponiéndole como carga al consumidor según el artículo 21 la demostración del defecto del bien, la existencia del daño y el nexo causal entre ambos.

Todo el tema de la responsabilidad exigible a productor y expendedor se enmarca en la responsabilidad civil; esta tiene como génesis en los hechos jurídicos que traen consigo la obligación de resarcir, por haberse infringido daño o perjuicio patrimonial, resarcimiento que se materializa en una indemnización de perjuicios.

En la actualidad la responsabilidad, la imputación de responsabilidad en materia de consumo de estudiar a partir de la responsabilidad objetiva, entendida como la inobservancia de normas de cautela, se funda en un deber de comportamiento que espera del productor o expendedor, teniendo en cuenta la actividad que desempeña. Esta responsabilidad prescinde del requisito de la infracción como punto de partida, y no recurre a la culpa como criterio de imputación objetiva.

En la interpretación de los Estatutos del Consumidor, se destaca que sus fundamentos de aplicación son excluyentes, en razón a la implementación funcionalista de la constitución de 1991, que se deriva a su vez, del constitucionalismo contemporáneo abanderado de los derechos fundamentales, a partir de su interpretación fundada en principios constitucionales preestablecidos, imperativos categóricos orientados a preservar la máxima de la dignidad humana. 
Sin embargo, y en un análisis académico del Estatuto de Protección al Consumidor, Ley 1480 de 2011, se concluye que no se presenta una derogatoria de las normas especiales de cada sector económico, ni establece obligaciones de resultado para todas aquellas circunstancias cuando resulte involucrado el consumidor con un productor o proveedor de cualquier producto o servicio, hecho que se considera poco acertado en un tema de vital trascendencia en el escenario económico.

El fenómeno socioeconómico de las pirámides o esquemas ponzi, que afectaron a gran parte de la clase media del país, es una manifestación más del ejercicio tardío de regulación estatal para este sector; se entiende por pirámide la estructura social que se sumerge en una red social, que se dota de información, relaciones, expectativas económicas de los individuos -su motor económico- y las circunstancias que traspasan la racionalidad limitada del individuo, aun colectiva ${ }^{1}$.

Al analizar el escenario económico de la población económicamente activa en Colombia se puede evidenciar cómo la decisión de invertir en una pirámide o esquema ponzi sería irracional y con ocasión de ello, es posible establecer a favor del Estado un eximente de responsabilidad, al momento de querer accionar ante la jurisdicción con el objeto de recuperar el capital invertido. Considerar lo contrario, es decir, que el Estado sí es responsable conllevaría a incentivar y fortalecer el marco jurídico, económico y de comportamiento irracional o por lo menos oportunista para que sigan apareciendo estos esquemas fraudulentos e ilegales.

Ahora bien, la promesa de altas rentabilidades, esto es, por encima de la inflación y sin fluctuaciones, que rebasan por disímiles escenarios la racionalidad limitada, es responsabilidad exclusiva del individuo que decide invertir en los esquemas ponzi o piramidales, dado que es aquel, quien asume el riesgo limitado por la racionalidad del derecho.

1. "Una pirámide, entonces, es una estructura social temporal incrustada en una red social más amplia, a la que "explota", en términos de contactos e información, para crecer”. (Salazar Trujillo \& Franco Escobar, 2009, p. 90) 
Bajo los anteriores argumentos, se reitera que no es posible endilgar responsabilidad al Estado por la entrega y posterior pérdida de dineros en los sistemas piramidales o ponzi, cuando la conducta que llevó al individuo a invertir en ellos, es ajena al querer estatal, se envuelve en la obtención de mayores intereses que los concedidos por el sector financiero, como también en omitir las obligaciones tributarias que resultaren de las ganancias, ocultando su capital al gobierno y al final pretendiendo que la justicia lo represente en su diversas causas.

Bajo una exploración cualitativa, se abordó el tema de las facultades jurisdiccionales de la Superintendencia de Industria y Comercio, establecidas por mandato legal, bajo el postulado respeto irrestricto a la constitución , por cuanto el legislador no goza de libertad absoluta para configurar el régimen de los derechos de los consumidores, lo que implica que la prevalencia del derecho a la igualdad ampara los actores involucrados en las relaciones de mercado, en particular para el consumidor. Lo anterior implica que en el país para el caso en estudio se aplica el principio de libertad configurativa de los regímenes de protección especial, por cuanto se subordina al cumplimiento razonable de los principios y derechos que fundan el sistema de defensa instituido por la Constitución, cuya competencia reglamentaría se encuentra a cargo del órgano democrático

Ahora bien, la asignación de funciones judiciales en cabeza de una autoridad administrativa, requirió de una regulación especial: la Ley estatutaria 270 de 1996, artículo 13, posteriormente la Ley 1285 de 2009, dispuso el trámite procedimental a partir del respeto por la garantía al debido proceso, y así mismo, reguló que las sentencias o decisiones definitivas que en asuntos judiciales profirieran las autoridades administrativas son susceptibles de control jurisdiccional, todo en concordancia con el artículo 113 constitucional conforme al cual, aunque los diferentes órganos del Estado tienen funciones separadas, colaboran armónicamente para la realización de sus fines. 
Son amplios los pronunciamientos de la Corte Constitucional a este respecto, verbigracia: administrativas la sentencia C-117 de 2008 estableció que las funciones judiciales y administrativas de inspección, vigilancia y control, deben ser ejecutadas por funcionarios diferentes y que en todo caso, las facultades judiciales son excepcionales C-415 de 2002, T-302 de 2011 haciendo expresa consideración a que la asignación "debe ser precisa, de modo que la materia sobre la cual recaiga sea puntual, exacta, que no pueda extenderse ni confundirse”, bajo el ámbito de la preservación al debido proceso y las garantías procesales.

Entre tanto, el tema de la doctrina probable, regulada en la Ley 1340 de 2009 en su artículo 24, debe entenderse bajo una interpretación restrictiva; así lo señaló la sentencia de constitucionalidad,, lo que significa que se aplica únicamente para la competencia administrativa de la SIC en materia de protección de la libre competencia. Para el máximo tribunal constitucional no hay prohibición constitucional para que a través de la ley se pueda establecer la figura de la doctrina probable de carácter administrativo. No obstante esta doctrina no tiene carácter de inmutable, podrá variarla siempre y cuando motive el acto administrativo con razones suficientes para evitar la vulneración de los principios de igualdad, seguridad jurídica, buena fe y confianza legítima, propios del Estado Social de Derecho.

Las funciones jurisdiccionales se realizan conforme el numeral $2^{\circ} \mathrm{del}$ artículo 14 del Decreto 3523 de 2009 que establece que al Superintendente delegado para asuntos jurisdiccionales le corresponde, "Adelantar de acuerdo con el procedimiento legalmente aplicable, en única o primera instancia según corresponda de acuerdo con la cuantía, el trámite de los procesos que deban iniciarse en ejercicio de las funciones jurisdiccionales de protección al consumidor”.

El tema también fue abordado por el Código General del Proceso, Ley 1562 de 2012, artículo 24, numeral 1, que atribuye competencia jurisdiccional a la SIC señalando las funciones de la SIC por violación a los derechos de los 
consumidores establecidos en el Estatuto del Consumidor y de las normas relativas a la competencia desleal.

Por último, y no por ello menos importante, se hace referencia al debido proceso, derecho que impregna todas las actuaciones en las relaciones de consumo; por ejemplo en el régimen de responsabilidad, en la imposición y cumplimiento de deberes, en favor de los consumidores y también del Estado. Es una doble vía, que lleva consigo su respeto irrestricto tanto en los procedimientos de orden judicial como administrativo que emanan de la protección constitucional y legal al consumidor.

El Estatuto del Consumidor Colombiano, Ley 1480 de 2011, supone algunos avances y transformaciones en la protección del consumidor comparados con su antecesor el Estatuto anterior, empezando porque las dimensiones constitucionales y los paradigmas de interpretación de los dos Estatutos del Consumidor, objeto de examen de la presente investigación, son totalmente diferentes, de ahí que se haya tenido que hacer un análisis de tales contextos para lograr la evidencia de los avances jurídicos que se han logrado en este marco.

Por una parte, la constitución de 1886 carecía de principios constitucionales inspiradores, que orientaran las normas legales, por lo cual estas resultaban ser más una organización sistemática de los temas a regular que un cuerpo coherente con la Carta Magna. El paradigma constitucional cambia con la Constitución de 1991, y las leyes empiezan a ser inspiradas por los principios rectores que además resultaban ser coadyuvantes en la tarea de la interpretación normativa, garantizando así un sistema jurídico coherente y fortalecido que brinda una mayor protección a los consumidores.

Desde este análisis, se encuentran diferencias consideradas fundamentales que trascienden a la esfera de protección elemental y que regulan materias que pueden ser consideradas no solo desde el punto de vista de protección al consumidor, sino desde la perspectiva del buen funcionamiento y 
desarrollo de los sectores productivos, el mercado, la competencia, así como el tema de la publicidad, la cual estaba enfatizada en la publicidad hecha a los productos como en el caso de las marcas y las leyendas de las propagandas, hacia una mención de que la información fuera la adecuada, de manera que se evitara incurrir en error a los consumidores Sin embargo, no se reglamentaba la distinción en cuanto al tema de la responsabilidad, en el suministro de la información.

En contraste, puede verse que la Ley 1480 de 2011 regula de manera distinta la información y la publicidad, lo que significa un gran avance en el control de la publicidad engañosa y la protección de la perfección del consentimiento en los contratos, basada en el conocimiento real y los criterios vinculantes de la publicidad, así como en la adquisición de productos perecederos, y la información sobre las condiciones especiales contenidas en los reglamentos técnicos para el correcto uso o consumo, conservación e instalación del producto o utilización del servicio.

Se establece además la responsabilidad solidaria del anunciante en cuanto a publicidad engañosa, cuando en su conducta medie dolo o culpa grave al publicar información no correspondiente a la realidad en un medio de comunicación.

En cuanto a protección contractual la Ley 1480 prohíbe la contratación o adquisición de bienes diferentes a los pretendidos por el consumidor para adquirir el que en realidad quiere y prohíbe atar contractualmente a los consumidores para adquirir o disfrutar los incentivos ofrecidos por el proveedor, es decir las ventas atadas las cuales no estaban reguladas por el Decreto 3466 de 1982.

El estatuto también regula las operaciones mediante sistemas de financiación, gracias a unas estipulaciones especiales, por las cuales se le debe informar al consumidor el monto a financiar y el interés moratorio según la tasa efectiva anual; también se le deberá informar sobre cobro de estudios de 
crédito, seguros, garantías o cualquier concepto adicional al precio, lo cual el anterior decreto no contemplaba.

Con el fin de garantizar la legalidad y la certeza jurídica de las resoluciones que se dicten en materia de protección al consumidor, se ha otorgado mediante poderes conferidos en la Constitución, específicamente atendiendo a las normas contenidas en la Ley 1285 de 2009 que modifica la Ley Estatutaria 270 de 1996, facultades jurisdiccionales a la SIC, para que conozca asuntos que por su naturaleza o cuantía puedan ser resueltas de manera adecuada y eficaz, y cuyas resoluciones deben enmarcarse en los postulados constitucionales.

En temas de competencia administrativa y en materia de protección a la libre competencia, se ha admitido el uso de la doctrina probable, pero no existe impedimento constitucional para adoptar esto en otros aspectos que puedan ser sancionados también en sede administrativa, puesto que por ahora no puede extenderse a las facultades jurisdiccionales, la cual podrá variar en este sentido, mediante argumentación razonada.

En cuanto a su aplicación en sede administrativa, del estudio se concluye que la SIC ha aplicado consecuentemente las consideraciones del Consejo de Estado, acordes además con las garantías establecidas en el texto constitucional, las cuales son de obligatorio cumplimiento para las entidades cuyas facultades jurisdiccionales están dadas no por la naturaleza de la misma entidad, sino por la misma garantía y efectividad que se debe al sujeto de protección.

Es en este contexto, el de los sujetos de protección, que surge un marco regulador concretado en figuras y herramientas jurídicas apropiadas y eficaces que sustituyen las normas de derecho dispositivo del derecho común, que replantean, por ejemplo, el concepto de contrato, tenido anteriormente solo como aquel acuerdo de voluntades en el que las partes de común acuerdo establecen el contenido de la norma reguladora de su relación contractual, sino que ahora amplía el concepto a los contratos de adhesión o predispuestos, 
cuya naturaleza contractual ha sido doctrinalmente sustentada y cuyo efecto jurídico es el mismo que el de la negociación.

Se replantea entonces el principio de la autonomía de la voluntad y el de la perfección del consentimiento, garantizado si el conocimiento de las cláusulas y del contenido contractual, que permita la aceptación informada de manera tal que no se ponga en tela de juicio la validez de las cláusulas contractuales. Esto supone que los controles establecidos en la norma estén enfocados a garantizar el consentimiento. Tal es el caso del control formal que se incorpora de manera solapada y no tan clara en la norma a través de unos deberes de información precontractual y postcontractual, que suponen la declaración de nulidad de la cláusula que aun siendo equilibrada, puede quedar por fuera del contrato por no haber sido conocida por el consumidor.

No obstante, antes de mirar la verdadera voluntad de las partes, el legislador, en un gesto proteccionista al consumidor, prevé la abusividad de ciertas cláusulas pese a lo que dispongan las partes, es decir, cláusulas que pueden ser válidas y consideradas justas en los contratos negociados, atendiendo a las circunstancias propias de su celebración, son, sin previo juicio, consideradas abusivas y nulas de pleno derecho, por el hecho de que una de las partes no participó en la elaboración de las mismas, sin importar si existen circunstancias particulares de negociación que puedan justificar su inclusión en el contrato.

Esto, porque la ley incorpora mecanismos de protección que se consideran irrenunciables en virtud no solo de la falta de poder negociador del consumidor, sino también de una supuesta debilidad ante su contraparte y de unos intereses que son considerados de orden público que justifica que se impongan ciertos límites al poder negociador derivado de la libertad de las partes para contratar.

Sin embargo, no se debe perder de vista que el único poder normativo que tienen las partes y la única fuente voluntaria de las obligaciones sigue 
siendo la autonomía, y en este sentido habrá casos en los que la responsabilidad del usuario o consumidor no puede ser trasladada al ente regulador, cuando este no actúa con la debida diligencia que se desprende de la misma norma jurídica.

Así, puede verse el caso de los usuarios de las llamadas pirámides o sistemas piramidales, cuyos implicados alegan en un principio el deber de vigilancia del Estado, por parte de la Superintendencia Financiera, lo que implicaría que su protección debe ser la de los usuarios del sistema financiero. Sin embargo, se evidenció que los estándares de protección de los que puedan ser titulares estos usuarios, implicaba determinadas conductas de su parte que constituyen esa diligencia debida.

Los consumidores también se encuentran protegidos en la protección a la libre competencia, cuyas prácticas restrictivas, según se evidenció, generan efectos adversos al comercio y a los agentes que intervienen en él, tanto a en el mercado de origen como en el mercado exportador.

En este sentido ha sido importante determinar el lugar de los efectos negativos que genera la cartelización de las empresas, para determinar el régimen jurídico aplicable. En Colombia, sin embargo, las leyes de competencia dejan abierta la posibilidad de su aplicación extraterritorial sin lugar a especificación alguna. La jurisprudencia ha sido muy escasa para determinar la aplicación de la legislación extraterritorialmente.

Esta protección no se queda sin embargo en el ámbito de lo privado, los consumidores de los servicios públicos también han sido objeto de este estudio, específicamente en lo que concierne a la regulación en la colusión en la contratación pública y los efectos nocivos que esta tiene en el desarrollo de este sector, así como los cambios normativos que se pretenden para poner a tono la legislación nacional en la materia con los estándares internacionales que permitan facilitar el ingreso del país a la OCDE, dentro de los que incluye un sistema de abastecimiento integral que conceda mayor margen a las 
entidades públicas y la reglamentación de los regímenes de inhabilidades, prohibiendo por demás, participar a personas jurídicas cuyos representantes hayan sido condenados por colusión, por un término de 20 años.

Sin embargo, en cuanto a temas de protección, resulta inquietante la posible implementación de un sistema de precalificación, por medio del cual una participación en principio dirigida al público, termine reduciéndose a un reducido grupo de interesados, lo que implica necesariamente la limitación de la competencia en el mercado correspondiente.

En tal sentido, la posibilidad de negociar las condiciones de un contrato estatal con un grupo reducido de oferentes podría limitar drásticamente las condiciones de igualdad en el mercado para los participantes, e incluso, podría afectar negativamente la manera en que se afecta el erario pues la negociación no se concibe como herramienta orientada exclusivamente al uso eficiente del erario.

Adicionalmente, el proyecto no contempla la posibilidad de rechazar una oferta por haberse demostrado un hecho indicador de una posible conducta colusoria.

Así las cosas, puede verse que el proyecto de reforma al Estatuto General de Contratación de la Administración Pública, trae herramientas limitadas para evitar la colusión, cuya imposición de sanciones continúa estando en cabeza de la Superintendencia de Industria y Comercio.

Este colofón cierra como se dio inicio a esta obra: recordando al profesor García Canclini en el ya clásico "Consumidores y ciudadanos": en el siglo XXI, además de consumidores somos ciudadanos y el acto de consumir -o abstenerse de ello- es, en esencia, un acto político.

Bourdieu también, desde otra perspectiva, en su obra la "Distinción” nos mostró como se puede analizar a las personas no solo en su posición en 
el acto de producción - como lo hicieron la economía y la sociología del siglo XIX y XX- sino también a través de los actos de consumo.

Esos principios y nociones que ya habían sido aprendidos por las ciencias sociales, poco a poco se han ido decantando en las disciplinas jurídicas. Ello se ha reflejado en los cambios en la forma de regulación después de la segunda guerra mundial. Primero en Estados Unidos y en Europa se dio forma legal a las preocupaciones por la protección al consumidor desde la perspectiva estatal. Posteriormente en casi todos los países del mundo, y en particular en Iberoamérica ${ }^{2}$ se han expedido normativas tendientes a la protección de los consumidores, entendiendo, como se mostró en esta obra, que hay un desequilibrio - se rompe la igualdad formal del derecho de contratos- en favor del poder del productor o vendedor y en perjuicio del consumidor.

En Colombia desde el Decreto 3466 de 1982 hasta la Ley 1480 de 2011 -primer y segundo “estatutos” en nuestra legislación- pasando por la Ley 1328 de 2009 - del consumidor financiero- y por centenares de decisiones de la SIC en materia de Protección al consumidor, se ha ido fortaleciendo un área que va de la mano con el desarrollo económico y social. El capitalismo- lo describió brillantemente- Weber en su clásica introducción a La Ética Protestante y el Espíritu del Capitalismo- no puede medirse solamente con el crecimiento de la industria y los mercados, pues el intercambio siempre ha existido, pero solo en el capitalismo ese intercambio no es violento y tiene unas profundas raíces éticas y morales, como no sucedió con ningún otro sistema o formación social de la historia. Y esas preocupaciones se vierten en la norma positiva.

\footnotetext{
2. Para una revisión general del derecho del consumidor en el espacio iberoamericano (incluyendo Norteamérica) ver el excelente trabajo coordinado por el profesor Julio Álvarez Rubio, editado en Granada en 2014 por Comares, con sello de la OEA, la Unión Europea, la Universidad de Cantabria, titulado: La Protección Jurídica de los Consumidores en el Espacio Euroamericano. Para el caso colombiano, ver en esa misma obra el capítulo de los profesores Luis Carlos Plata y Vladimir Monsalve, titulado: Derecho del Consumo en Colombia: Antecedentes, situación actual y perspectivas de futuro. Para el caso argentino hay un capítulo en la misma obra escrito por el profesor Barocelli, o puede consultarse la obra titulada Manual de Derecho del Consumidor con Edición de Abeledo Perrot de Buenos Aires y Coordinación del Dr. Rusconi. Una excelente introducción al derecho del consumidor en Colombia la proporciona el texto del Profesor Juan Carlos Villalba Cuellar, Introducción al Derecho del Consumo editado por la Universidad Militar Nueva Granada en el año 2012 o con coordinación del mismo Dr. Villalba y del Dr. José Manuel Gual Acosta, El Derecho del Consumo con edición de Ibañez y USTA en Bogotá en el año 2013.
} 
Y el siguiente paso a la positivización de la protección de un sector social - en este caso- los consumidores, solo puede darse con el ejercicio de los derechos y acciones que la ley otorgó para que el derecho de acción haga "efectivo en la realidad" el derecho sustancial. Y a partir de normas, la doctrina y la jurisprudencia ${ }^{3}$ se va haciendo del sueño del legislador, la realidad cotidiana de la protección de los derechos. Por ello esta obra tocó tanto los aspectos sustanciales como procesales en esta materia.

Pero como se mencionó en el capítulo introductorio y a lo largo de la obra son dos caras de la misma moneda el derecho del consumidor y el de la competencia. Así se incluyeron dos capítulos: uno dedicado a los oligopolios (carteles) y otro a la colusión anticompetitiva en el mercado. Ello porque los más recientes "escándalos" o efectos de las investigaciones de la SIC demostraron que en materias tan sensibles- y esto no es sarcasmo- como los pañales, el papel higiénico, los cuadernos o el arroz, las prácticas anticompetitivas no solamente afectan la teórica libertad de mercado o la libre competencia, sino que al final el más afectado es el consumidor.

Por todo ello, creemos y deseamos que esta obra logré contribuir a seguir ampliando los materiales de estudios iuspositivistas y socio-económicos acerca de la legislación y práctica del Derecho del Consumidor y de la Competencia. Para el Politécnico Gran Colombiano y para la Universidad La Gran Colombia, es además el primer paso en el que esperamos sea un largo camino de colaboración investigativa y editorial.

Como muchas cosas en Colombia el recorrido de la protección al consumidor y la competencia se ha iniciado hace algún tiempo, pero debemos seguir en él, para poder tener logros más concretos, más eficaces día a día, y este texto espera ayudar en ese trasegar que no es uno distinto que el de la justicia y la libertad.

\footnotetext{
3. Recordemos que el artículo 24 del Código General del Proceso otorga facultades jurisdiccionales residuales a la Superintendencia de Industria y Comercio en materias de protección al consumidor. Otras normas otorgan facultades de protección a entidades como la Superintendencia Financiera y la Dirección de Aeronáutica Civil entre otras autoridades.
} 
